\title{
LOS PRINCIPIOS DE UNIDROIT SOBRE LOS CONTRATOS COMERCIALES INTERNACIONALES Y LOS EFECTOS DERIVADOS DEL COVID-19 SOBRE LAS RELACIONES CONTRACTUALES: UNA PERSPECTIVA DESDE EL DERECHO ESPAÑOL
}

\author{
THE UNIDROIT PRINCIPLES ON INTERNATIONAL \\ COMMERCIAL CONTRACTS AND THE EFFECTS DERIVED \\ FROM COVID-19 ON CONTRACT RELATIONS: \\ A PERSPECTIVE FROM THE SPANISH LAW
}

\author{
Carlos Manuel Díez Soto \\ Catedrático de Derecho Civil \\ Universidad de Murcia \\ IsABel GonzÁlez PaCANOWSKA \\ Catedrática de Derecho Civil \\ Universidad de Murcia
}

Recibido: 17.01.2021 / Aceptado: 23.01.2020

DOI: https://doi.org/10.20318/cdt.2021.5957

\begin{abstract}
Resumen: La Nota publicada el pasado 15 de julio 2020 por el Secretariado de Unidroit, relativa a los Principios Unidroit sobre Contratos Comerciales Internacionales en la crisis sanitaria de la Covid-19, pretende ofrecer una guía sobre el modo en que los Principios pueden servir como un útil instrumento para afrontar, en términos jurídicamente adecuados, algunos de los problemas típicos que se están suscitando como consecuencia de la pandemia y de las medidas adoptadas para paliar sus efectos, así como la crisis económica derivada. La magnitud de la crisis impone sin duda la necesidad de articular medidas legales específicas, inspiradas por criterios de justicia distributiva (y no solo conmutativa). Se trata, además, de evitar que el recurso a los instrumentos generales provoque el colapso de los tribunales, a lo que se une el inconveniente de la disparidad de criterios y la inevitable lentitud en la construcción de guías jurisprudenciales. La legislación de emergencia no podrá, sin embargo, ofrecer una solución satisfactoria a todos los conflictos que se vienen planteado y seguirán surgiendo en el futuro próximo, y es en este terreno donde tendrá que acudirse a los conceptos generales. La Nota aporta interesantes perspectivas a la hora de interpretar y aplicar las normas nacionales que regulan las instituciones básicas de obligaciones y contratos, en especial las relacionadas con las nociones de fuerza mayor/caso fortuito, y excesiva onerosidad sobrevenida/rebus sic stantibus. En este artículo, siguiendo una sistemática expositiva paralela a la de la propia Nota, se centra el foco, no tanto en la legislación de emergencia, sino más bien en el modo en que tanto los Principios como las sugerencias de la Nota pueden ser aprovechados para plantear posibles soluciones en el contexto del ordenamiento jurídico español, con una atenta consideración a los planteamientos de la jurisprudencia, sobre todo de los últimos años, y al entendimiento de las nociones de fuerza mayor y caso fortuito, imposibilidad, excesiva onerosidad sobrevenida, así como el ámbito de aplicación, los presupuestos y los efectos de la regla rebus.
\end{abstract}


Palabras clave: Covid-19, Principios Unidroit sobre los Contratos Comerciales Internacionales, fuerza mayor, imposibilidad, excesiva onerosidad sobrevenida, incumplimiento contractual.

Abstract: The Note published on July 15th 2020 by the Unidroit Secretariat on the Unidroit Principles of International Commercial Contracts and the Covid-19 health crisis seeks to offer guidance on how the Principles could help as a useful tool to address the main contractual disruptions caused by the pandemic and by the measures taken to mitigate its effects, as well as the ensuing economic crisis. The magnitude of the crisis undoubtedly demands specific legal measures, inspired by criteria of distributive justice (and not just commutative). It is also a question of preventing an overwhelming burden of the justice system, as well as the drawbacks of criteria disparities and the unavoidable slowness in the development of consolidated jurisprudential guidelines. Emergency legislation, however, will not be able to provide satisfactory solutions to all the conflicts that have arisen and will continue to arise in the near future, and it is in this area where general concepts will have to be used. The Note provides interesting insights into the interpretation and application of national rules governing the basic institutions of obligations and contracts, in particular those related to the notions of force majeure/fortuitous event, impossibility and hardship/rebus sic stantibus. In this article, following the same structure as the Note itself, the focus is not so much on emergency legislation, but rather on the way in which both the Principles and the suggestions of the Note can be used in order to propose possible solutions in the context of the Spanish legal system, taking into account the evolution of caselaw, especially of recent years, and the understanding of the notions of force majeure and fortuitous case, impossibility, hardship, as well as the scope, the requirements and the effects of the rebus rule.

Keywords: Covid-19, Unidroit Principles on International Commercial Contracts, force majeure, impossibility, hardship, breach of contract.

Sumario: I. Consideraciones generales. 1. La Nota del Secretariado de Unidroit sobre los Principios de Unidroit relativos a los Contratos Comerciales Internacionales y la crisis sanitaria del Covid-19. 2. La perspectiva desde el Derecho español de obligaciones y contratos: legislación de emergencia y mecanismos generales. 3. El desarrollo de la crisis en España. II. La fuerza mayor. 1. El concepto de fuerza mayor en los Principios: la noción de "impedimento para el cumplimiento" y la imposibilidad sobrevenida de la prestación. 2 . El régimen de la imposibilidad originaria de la prestación en los Principios y en el CC. 3. Los requisitos de la fuerza mayor en los Principios y en el Código Civil: eventos ajenos al control del deudor; imprevisibilidad; inevitabilidad; razonabilidad. 4. Los requisitos de la fuerza mayor exoneradora y/o liberatoria en el contexto de la crisis generada por el coronavirus. A) Las circunstancias del caso concreto. B) La esfera de control de las partes. C) La previsibilidad. D) Las cláusulas contractuales ad hoc. E) El carácter insuperable o inevitable de los impedimentos. 5. Los deberes adicionales impuestos a las partes. A) La obligación de notificar al acreedor la existencia del impedimento. B) El deber del acreedor de mitigar el daño. C) Principio de buena fe y deber de cooperación entre las partes. 6. Posibilidad de acudir a otros remedios. III. Excesiva onerosidad (hardship). 1. El deber de cumplir el contrato a pesar de la excesiva onerosidad sobrevenida y la adaptación o la resolución contractual como excepción en los PICC. 2. La situación de hardship en los Principios: aumento de coste de la prestación propia o disminución de valor de la que se recibe. 3. La doctrina rebus en la jurisprudencia del Tribunal Supremo. A) La excesiva onerosidad sobrevenida en puertas del Covid-19. B) La frustración del fin del contrato. C) Crisis y dificultades económicas del deudor. 4. Las circunstancias sobrevenidas y su incidencia causal sobre la excesiva onerosidad. 5. Los requisitos adicionales para invocar la excesiva onerosidad en los Principios y en la jurisprudencia del Tribunal Supremo. Aplicación en tiempos de crisis COVID. A) Circunstancias sobrevenidas a la celebración del contrato. B) Eventos que no pudieron ser razonablemente tenidos en cuenta por la parte perjudicada en el momento de celebrarse el contrato y que escapan a su control. C) La asunción del riesgo por la parte perjudicada. D) Cláusulas específicas sobre asignación de riesgos. 6. Los efectos de la excesiva onerosidad. A) Renegociar. Esa es la cuestión. B) La regla supletoria en defecto de acuerdo. 7. Propuestas normativas para codificar la rebus en tiempos de crisis. IV. Conclusiones. 


\section{Consideraciones generales}

\section{La Nota del Secretariado de Unidroit sobre los Principios de Unidroit relativos a los Contratos Comerciales Internacionales y la crisis sanitaria del Covid-19}

1. El pasado 15 de julio de 2020 el Secretariado del Instituto Internacional para la Unificación del Derecho Privado (UNIDROIT) publicó una Nota relativa a la interpretación y aplicación de los Principios de Unidroit relativos a los Contratos Comerciales Internacionales en el contexto de la crisis sanitaria, social y económica generada por el COVID-191. La Nota pretende ofrecer al lector una guía sobre el modo en que los Principios pueden servir como un útil instrumento para afrontar en términos jurídicamente adecuados algunos de los problemas típicos que se están suscitando en todo el mundo como consecuencia del impacto que, no solo la pandemia en sí misma, sino también las medidas adoptadas por los diferentes Gobiernos para atajarla y paliar sus efectos, así como la crisis económica derivada, están teniendo sobre la actividad económica en general y, en particular, sobre el normal desarrollo de las relaciones contractuales.

2. Tras recordar el importante papel que los Principios vienen cumpliendo, desde su primera formulación en 1994, como instrumento de armonización del Derecho de contratos a nivel internacional (con su correspondiente reflejo en la negociación y redacción de los contratos, en las legislaciones nacionales y supranacionales, en la labor de los tribunales nacionales e internacionales y en el terreno de los mecanismos de solución extrajudicial de conflictos), el documento aborda una "descripción del caso" en la que se exponen de forma sintética los principales hitos por los que ha atravesado el proceso de expansión de la enfermedad desde la aparición de sus primeras manifestaciones en China a finales de 2019 hasta el momento en que (coincidiendo con la elaboración de la Nota) la misma alcanza la dimensión de una pandemia mundial, así como un examen de los principales tipos de medidas que se vienen adoptando por parte de los diferentes Gobiernos, y que, en muchos casos, llevan consigo una paralización total o parcial de la actividad económica y social y, en consecuencia, un obstáculo para el normal desenvolvimiento de las relaciones contractuales.

3. Centrando su atención en el terreno contractual, y en línea con la que viene siendo la communis opinio entre los juristas que en todos los países están estudiando el tema, la Nota centra su análisis en la posibilidad y oportunidad de reconducir muchos de los problemas así planteados a dos instrumentos clásicos del Derecho de obligaciones y contratos, que cuentan con una regulación específica en los Principios: la fuerza mayor, como causa de exoneración de la responsabilidad por incumplimiento, y la excesiva onerosidad sobrevenida (hardship), como fundamento de una posible renegociación o revisión de los términos del contrato ante un cambio extraordinario de circunstancias². Con una cuidada técnica jurídica, y haciendo un acertado uso de los ejemplos, el documento va examinando detenidamente los diferentes aspectos de la regulación contenida en los Principios a propósito de los citados mecanismos (presupuestos, requisitos, efectos...) a la luz de las cambiantes circunstancias que han ido surgiendo en

\footnotetext{
${ }^{1}$ Accesible en español en la página https://www.unidroit.org/spanish/news/2020/200721-principles-covid19-note/note-s.pdf.

${ }^{2}$ Significativamente, ambos instrumentos aparecen mencionados conjuntamente en los "Principios para la crisis del Covid" propuestos por el European Law Institute (disponibles en https:/www.europeanlawinstitute.eu/fileadmin/user_upload/p_eli/ Publications/ELI_Principles_for_the_COVID-19_Crisis.pdf). Concretamente, el Principio $13^{\circ}$ se pronuncia en los siguientes términos: "Force majeure and hardship (1) Where performance of a contract is temporarily or definitively prevented directly or indirectly due to the COVID-19 outbreak or the European States' decisions taken in relation with the COVID-19 outbreak, States should ensure that existing law on impossibility or force majeure apply in an effective way, and provide reasonable solutions. In particular, the contractual allocation of risk in these instances should be evaluated in the light of existing contracts, background legal regime and the principle of good faith. (2) Where, as a consequence of the COVID-19 crisis and the measures taken during the pandemic, performance has become excessively difficult (hardship principle), including when cost of performance has risen significantly, European States should ensure that, in accordance with the principle of good faith, parties enter into re-negotiations even if this has not been provided for in a contract or in existing legislation. (3) In conformity with the principle of solidarity, States should ensure that the consequences of the disruption of contractual relationships, such as the cancellation of travel arrangements, should not be at the sole risk of one party, in particular of a consumer or SME".
} 
el curso de la evolución experimentada por la pandemia en los distintos países, tomando especialmente en consideración, por razones obvias, las relaciones contractuales de naturaleza comercial y de carácter internacional.

\section{La perspectiva desde el Derecho español de obligaciones y contratos: legislación de emergencia y mecanismos generales.}

4. Hay que recordar que entre las funciones que se atribuyen a los Principios, según su propio Preámbulo, está la de aportar criterios de interpretación e integración de los Derechos nacionales; y, en este sentido, el presente trabajo pretende recoger el guante, analizando, con un método comparativo, el modo en que tanto los propios Principios, como las sugerencias e indicaciones que propone la Nota, pueden ser aprovechados para plantear posibles soluciones y respuestas a la actual crisis en el contexto del vigente ordenamiento jurídico español, atendiendo a las especiales circunstancias que se han dado en nuestro país durante los últimos meses. Para ello, seguiremos, a grandes rasgos, una sistemática expositiva paralela a la de la propia Nota, centrando el foco, no tanto en la heterogénea legislación de emergencia dictada en los últimos meses (a la que, sin embargo, dedicaremos alguna atención), sino más bien en la interpretación y aplicación de ciertos mecanismos generales del Derecho español de obligaciones y contratos, como el régimen del caso fortuito, la imposibilidad sobrevenida de la prestación por causa no imputable al deudor, o la doctrina jurisprudencial sobre la cláusula rebus sic stantibus.

5. La oportunidad del planteamiento expuesto parece clara, habida cuenta de que el vigente ordenamiento español sigue manteniendo a propósito de estas figuras (y, en general, en el ámbito de la teoría general de obligaciones y contratos) una regulación (la procedente de la redacción original del Código Civil de 1889) que en la actualidad resulta claramente insuficiente en sus términos literales; aun reconociendo que su interpretación y aplicación práctica se ha visto notablemente enriquecida por la labor de la jurisprudencia (y la doctrina), muy especialmente a raíz de la necesidad de atender a los problemas derivados de la crisis financiera de 2008, que supuso para el sistema del Código Civil una dura "prueba de estrés" llamada, al parecer, a repetirse ahora.

6. Parece evidente que el recurso a mecanismos propios de la teoría general de obligaciones, como son la fuerza mayor y la excesiva onerosidad, cuya activación puede conducir fácilmente al planteamiento de litigios ante los Tribunales y, eventualmente, a la extinción de las relaciones contractuales preexistentes, debe plantearse en la situación actual como una solución subsidiaria. Como han señalado diversos autores ${ }^{4}$, la magnitud de la crisis impone la necesidad de articular medidas legales ad hoc, ba-

\footnotetext{
${ }^{3}$ Sobre las limitaciones que, a la hora de afrontar la actual crisis, presenta la vigente legislación española en materia de fuerza mayor y excesiva onerosidad sobrevenida, frente a las iniciativas que se han venido adoptando en los países de nuestro entorno y en otras instancias internacionales, v. Gómez Ligüerre, C.I., "Fuerza mayor", en InDret, 2/2020, op. cit., pp. 5 y ss., que destaca, en particular, la ausencia en nuestro ordenamiento de una regulación general positiva sobre la alteración sobrevenida de las circunstancias, similar a la que se da en otros sistemas (pp. 7-8): "A pesar de su generalidad, tales normas permiten que los gobernantes de aquellos países se centren en la adopción de medidas excepcionales y temporales que resuelven problemas concretos de contratos concretos o de contratantes específicos con la tranquilidad de que el resto de casos dispone de una regulación general para un supuesto como el causado por la crisis sanitaria". Y añade: "Acaso alguna de las normas o propuestas indicadas pudiera incluirse en la legislación de urgencia dictada con motivo de la crisis causada por la Covid-19. La situación exige una intervención del legislador que diera a los contratantes, primero, y a nuestros jueces y tribunales, después, un marco claro de actuación, especialmente urgente en atención a los escasos mimbres normativos con los que cuenta nuestro derecho de obligaciones para dar respuesta a una situación tan extrema como la que nos toca vivir ahora”. En p. 3, no obstante, el propio autor advierte sobre la dificultad que supone dictar normas con carácter general y vocación de permanencia en tiempos de crisis.

${ }^{4} \mathrm{~V}$. al respecto las interesantes reflexiones de Ganuza, J.J., y Gómez Pomar, F., "Los instrumentos para intervenir en los contratos en tiempos de COVID-19: guía de uso", en InDret, 2/2020, pp. 558 a 584, especialmente en pp. 560 a 562, donde destacan la necesidad de abordar las consecuencias de la crisis con medidas "sistémicas y urgentes", de amplio alcance y eficacia temporal, y con un bajo coste de aplicación, y no mediante el recurso a instrumentos (como la doctrina de la cláusula rebus sic stantibus) que pueden exigir una intervención judicial basada en la consideración de las circunstancias del caso concreto. V.
} 
sadas en mecanismos de justicia distributiva (y no solo de justicia conmutativa, como corresponde a los instrumentos señalados) que garanticen, ante todo, la imprescindible protección de los sectores sociales y económicos más perjudicados por la crisis; pero que permitan también abordar de un modo expeditivo y eficiente el ingente número de situaciones conflictivas que previsiblemente se van a plantear, y cuya solución no puede hacerse depender de decisiones judiciales más o menos inciertas $\mathrm{y}$, sin duda, dilatadas en el tiempo; procurando, además, en lo posible, mantener la vigencia del entramado contractual preexistente, que habrá de constituir sin duda un factor clave para la futura reactivación económica.

7. Al igual que ha sucedido en otros países de nuestro entorno, el Estado español, a través de sus diferentes instancias legislativas y ejecutivas (tanto estatales como autonómicas) ha venido dictando una amplia legislación de emergencia concretada en numerosas disposiciones legales y reglamentarias. Limitándonos al examen de las normas dotadas de un rango legal, la mayor parte de las medidas de emergencia han sido adoptadas mediante la promulgación por el Gobierno nacional de un amplio número de Reales Decretos-Ley en los que se han abordado todo tipo de cuestiones, incluyendo, en algunos casos, previsiones que afectan, normalmente con carácter temporal, al contenido de las relaciones contractuales entre particulares ${ }^{5}$, y en las que, en ocasiones, se detectan referencias más o menos explícitas a la noción de fuerza mayor, a la cláusula rebus sic stantibus, o a la conveniencia de propiciar el acuerdo de las partes en la renegociación de los contratos afectados por el cambio sobrevenido de circunstancias (incluso en ámbitos dominados por normas imperativas, como los contratos de consumo o los arrendamientos urbanos). No se trata de disposiciones de alcance general ${ }^{6}$, sino referidas a ciertos tipos de contratos de especial relevancia económica y social (contratos de financiación, arrendamientos urbanos, suministro de servicios esenciales, contratos de consumo), y orientadas a reforzar la protección de determinados colectivos a los que se considera especialmente perjudicados por las consecuencias directas e indirectas de la crisis: personas y familias vulnerables desde el punto de vista económico y social, autónomos, PYMES, consumidores y usuarios, empresas vinculadas al sector turístico o de transportes, etc.

8. En una buena parte de los casos, las medidas adoptadas consisten en moratorias, suspensión de ejecuciones y aplazamientos temporales de pago en contratos de financiación, incluyendo préstamos y créditos hipotecarios para la adquisición de vivienda habitual o de inmuebles afectos a ciertas actividades económicas, créditos de consumo, créditos con otras garantías inscribibles y especialmente orientados a PYMES y autónomos (como el arrendamiento financiero), y créditos destinados a empresas del sector turístico o de transportes ${ }^{7}$. También se han establecido diferentes medidas encaminadas a

también Morales Moreno, A., "El efecto de la pandemia en los contratos: ¿es el derecho ordinario de contratos la solución?", en $A D C$, t. LXXIII, 2020, fasc. II, pp. 447 a 454, donde explica que los instrumentos generales del Derecho de obligaciones y contratos, como la fuerza mayor o la doctrina de la cláusula rebus sic stantibus, basados en criterios de justicia conmutativa, no son adecuados para resolver la abrumadora incidencia de la crisis del coronavirus sobre el entramado de relaciones contractuales, para lo que se requiere una intervención directa y extraordinaria del legislador basada en criterios uniformes de justicia distributiva que tengan en consideración dos ideas fundamentales: la conservación de los contratos y la protección de la parte vulnerable; todo ello al margen de los inconvenientes inherentes a la judicialización de los conflictos (lentitud, coste económico, riesgo de falta de uniformidad en los criterios aplicados).

${ }^{5} \mathrm{Y}$ que en bastantes casos han sido objeto de modificaciones posteriores con objeto de ampliar o limitar su vigencia, o para retocar algunos aspectos concretos de su regulación.

${ }^{6}$ Recuérdese, no obstante, que el propio RD 463/2020, por el que se declaraba el estado de alarma, disponía en sus Disps. Adics. $2^{\mathrm{a}}$ y $4^{\mathrm{a}}$ (posteriormente derogadas) la suspensión de plazos procesales y de los plazos de prescripción y caducidad de cualesquiera derechos y acciones durante el plazo de vigencia del estado de alarma y de sus sucesivas prórrogas.

${ }^{7}$ V. RDLey 6/2020, de 10 de marzo, adoptado en vísperas de la declaración del estado de alarma, pero teniendo ya presente la crisis generada por el coronavirus, que refuerza y amplía las medidas legales preexistentes relativas a la suspensión de los lanzamientos consiguientes a la ejecución de garantías hipotecarias sobre la vivienda habitual cuando los mismos hubieran de afectar a personas y familias especialmente vulnerables (art. 2). El RDLey 8/2020, de 17 de marzo, dispone asimismo una moratoria en el pago de las deudas hipotecarias en beneficio de determinados deudores calificados como vulnerables (arts. 7 a 16 ter, luego modificados por Disp. Final $8^{\text {a }}$ RDLey 26/2020), no solo en relación con la adquisición de la vivienda habitual, sino también respecto a inmuebles afectos a la actividad económica de empresarios o profesionales, y a viviendas distintas de la habitual destinadas al alquiler, cuando el arrendador se vea afectado por la moratoria o suspensión en el pago de las deudas arrendaticias. El RDLey 11/2020, de 31 de marzo, modifica las condiciones subjetivas para la aplicación de la moratoria para créditos hipotecarios, amplía sus límites temporales, y extiende la moratoria y la suspensión de obligaciones a determinados 
garantizar el suministro de servicios esenciales (agua, electricidad, gas, servicios de comunicaciones), disponiendo asimismo moratorias, aplazamientos, fraccionamientos y otras facilidades de pago para los usuarios ${ }^{8}$.

9. En materia de contratos de consumo, y al margen de disposiciones encaminadas a interrumpir, durante la vigencia del estado de alarma, los plazos para la devolución de productos comprados on line o presencialmente por los consumidores ${ }^{9}$, cabe destacar especialmente las medidas adoptadas en el art. 36 del RDLey $11 / 2020$, de 31 de marzo ${ }^{10}$, que regula el derecho de resolución sin penalización de determinados contratos por parte de los consumidores y usuarios. La norma se refiere a los contratos de compraventa de bienes y prestación de servicios destinados a consumidores y usuarios cuya ejecución haya devenido imposible como consecuencia de las medidas adoptadas para combatir la crisis sanitaria ${ }^{11}$. En estos casos, se reconoce a los consumidores el derecho a resolver el contrato durante un plazo de catorce días desde que se constata la imposibilidad, aunque se advierte que "la pretensión de resolución sólo podrá ser estimada cuando no quepa obtener de la propuesta o propuestas de revisión ofrecidas por cada una de las partes, sobre la base de la buena fe, una solución que restaure la reciprocidad de intereses del contrato" 12 .

préstamos y créditos sin garantía hipotecaria (incluyendo, en virtud de una modificación posterior, a los arrendamientos financieros), cuando tienen por destinatarios a personas en situación de vulnerabilidad económica (arts. 16 y ss., posteriormente modificados por Disp. Final $9^{a}$ RDLey 26/2020). En las dos normas citadas en último lugar (y también en el posterior RDLey 19/2020) las medidas de protección alcanzan también a fiadores, avalistas e hipotecantes no deudores en situación de vulnerabilidad. El RDLey 15/2020, de 21 de abril, dedica su Disp. Adic. $15^{\mathrm{a}}$ a la formalización notarial de los aplazamientos derivados de las moratorias relativas a créditos o préstamos con garantía inscribible. El RDLey 19/2020, de 26 de mayo, regula también, de forma pormenorizada, las moratorias convencionales suscritas al amparo de acuerdos marco sectoriales adoptados, como consecuencia de la crisis sanitaria, en el seno de asociaciones representativas de entidades financieras (arts. 6 a 8 y Disp. Transitoria $1^{a}$ ), con el propósito de facilitar la posibilidad de que las partes de los contratos de financiación otorgados por tales entidades puedan acordar moratorias y aplazamientos más allá del ámbito cubierto por las moratorias legales previstas en la legislación de emergencia, y de las convencionales que puedan acordar las partes al amparo de la autonomía privada, contribuyendo así a paliar en mayor medida las negativas consecuencias económicas de la crisis. El RDLey 25/2020, de 3 de julio, incluye, entre las medidas para la reactivación económica en el sector turístico, especialmente afectado por las consecuencias de la pandemia, la regulación de la moratoria de préstamos hipotecarios otorgados para la financiación de inmuebles afectos a una actividad turística (arts. 3 a 9 y Disp. Adic. $3^{\text {a }}$ ). Finalmente, el RDLey 26/2020, de 7 de julio, establece, entre otras medidas para la reactivación económica en el sector de los transportes, una moratoria para los contratos de financiación concedidos a empresas dedicadas al transporte por carretera (arts. 18 a 23 ).

${ }^{8}$ El RDLey 8/2020, de 17 de marzo, establece determinadas garantías para el suministro de agua y energía a consumidores vulnerables (art. 4) y para el acceso a los servicios de comunicaciones electrónicas y a la conectividad de banda ancha (arts. 18 a 20), considerados esenciales en situaciones de limitación de los desplazamientos, prohibiendo temporalmente su suspensión o interrupción en caso de incumplimiento del consumidor. El RDLey 11/2020, de 31 de marzo, regula igualmente la garantía de suministro de energía eléctrica, productos derivados del petróleo, gas natural y agua (art. 29, posteriormente modificado por Disp. Final $9^{a}$ RDLey 26/2020), y establece medidas orientadas a flexibilizar las condiciones de determinados contratos de suministro de energía para ajustarlas a las nuevas pautas de consumo impuestas por la pandemia y las medidas de contención, incluyendo la posibilidad de solicitar la suspensión de los contratos (arts. 42 y ss.). Por su parte, el RDLey 19/2020, de 26 de mayo, incluye algunas medidas adicionales relativas al fraccionamiento y aplazamiento de deudas en los servicios de comunicaciones electrónicas (art. 3). Finalmente, v. RDLey 37/2020, de 22 de diciembre, cuya Disp. Adic. $4^{\text {a }}$ complementa y refuerza la garantía de suministro de agua, gas natural y electricidad a consumidores vulnerables.

${ }_{9}^{9}$ Art. 21 RDLey 8/2020, de 17 de marzo. A la vista de la Exposición de Motivos, el precepto parece pensado fundamentalmente para las devoluciones derivadas del ejercicio por el consumidor del derecho de desistimiento legal o contractualmente reconocido; en este sentido, Gregoraci, B., "El impacto del COVID-19 en el Derecho de contratos español", en $A D C$, t. LXXIII, 2020, fasc. II, p. 480.

${ }^{10}$ Posteriormente modificado por Disp. Final $10^{\text {a }}$ RDLey 15/20202 y por Disp. Final $5^{\text {a }}$ RDLey 21/2020.

${ }^{11}$ Entiende M.P. García Rubio ("Medidas regladas en materia de contratos con motivo del COVID-19 en España", en Revista de Derecho Civil, vol. VII, núm. 2, especial, mayo 2020, p. 37) que deben incluirse en el espíritu de la norma los casos en que el cumplimiento del contrato no se haya hecho imposible, pero sí excesivamente oneroso para alguna de las partes como consecuencia del estado de alarma.

${ }^{12}$ Las propuestas de revisión, sigue diciendo el precepto, podrán abarcar, entre otras, el ofrecimiento de bonos o vales sustitutorios al reembolso; a estos efectos, se entenderá que no cabe obtener propuesta de revisión cuando haya transcurrido un periodo de 60 días desde que el consumidor formula su solicitud de resolución sin que haya acuerdo entre las partes sobre la propuesta de revisión. La posibilidad de que cualquiera de las partes pueda formular una propuesta de revisión del contrato parece responder, según GARCía RuBio (op. cit., p. 38), a la lógica de la rebus sic stantibus. 
10. En el caso de contratos de prestación de servicios de tracto sucesivo, el mismo art. 36 excluye inicialmente la resolución (rescisión, dice la norma), salvo que ambas partes estén de acuerdo, y solo se prohíbe el cobro de nuevas cuotas hasta que el servicio pueda volver a prestarse con normalidad. En estos supuestos, se dispone que la empresa prestadora de servicios podrá ofrecer opciones de recuperación del servicio a posteriori; y solo si el consumidor no pudiera o no aceptara dicha recuperación, se establece que habrá de procederse a la devolución de los importes ya abonados en la parte correspondiente al periodo del servicio no prestado por dicha causa o, previa aceptación del consumidor, a minorar la cuantía que resulte de las futuras cuotas que hayan de imputarse por la prestación del servicio.

11. En lo que se refiere a los contratos de viaje combinado que hayan sido cancelados con motivo de la crisis, se dispone que el organizador o, en su caso, el minorista, podrán entregar al consumidor o usuario, previa aceptación de este, un bono para ser utilizado dentro de un año desde la finalización de la vigencia del estado de alarma y sus prórrogas, por una cuantía igual al reembolso que hubiera correspondido. Transcurrido el periodo de validez del bono sin que haya sido utilizado, el consumidor podrá solicitar el reembolso completo de cualquier pago realizado ${ }^{13}$.

12. En materia de arrendamientos urbanos, destacan las medidas relativas a la suspensión de procedimientos de desahucio y lanzamiento, prórroga extraordinaria de los contratos, y moratoria o quita parcial de la deuda arrendaticia; medidas que se establecen, no solo en beneficio de los arrendatarios de vivienda en situación de vulnerabilidad, sino también respecto a arrendamientos para uso distinto o de industria cuyos arrendatarios son PYMES o autónomos. Por lo que ahora interesa, cabe destacar las previsiones contenidas en el RDLey 11/2020 (arts. 1 y ss. ${ }^{14}$ ), en el que se subraya la conveniencia de evitar que el refuerzo en la protección de los arrendatarios de vivienda pueda trasladar la vulnerabilidad de estos a los pequeños arrendadores, propiciando, a tal efecto, los acuerdos entre las partes para facilitar el pago de las rentas (v. especialmente art. 8) ${ }^{15}$. Aún más significativo es, en este sentido, el RDLey 15/2020, de 21 de abril, que incluye diferentes medidas orientadas a reducir los costes de PYMES y autónomos afectados en su capacidad de pago por la crisis mediante el aplazamiento temporal y extraordinario en el pago de la renta de los arrendamientos para uso distinto del de vivienda o de industria (arts. 1 a 5$)^{16}$. Especial interés, a los efectos de nuestro trabajo, reviste la justificación incluida en la Exposición de Motivos (ap. II) acerca de estas medidas, en la que se alude expresamente a las limitaciones que presenta el régimen general de la fuerza mayor en el Código Civil, y se propone una regulación

\footnotetext{
${ }^{13}$ No obstante lo anterior, el organizador, o en su caso el minorista, deberán proceder a efectuar el reembolso a los consumidores y usuarios en el supuesto de que estos soliciten la resolución del contrato, de conformidad con lo previsto en el art. 160.2 TRLGDCU, siempre que los proveedores de servicios incluidos en el contrato de viaje combinado hubieran procedido a la devolución total del importe correspondiente a sus servicios. Si solo algunos de los proveedores de servicios del viaje combinado efectuaran la devolución al organizador o, en su caso, al minorista, o la cuantía devuelta por cada uno de ellos fuera parcial, el consumidor o usuario tendrá derecho al reembolso parcial correspondiente a las devoluciones efectuadas, siendo descontado del importe del bono entregado por la resolución del contrato. Sobre la conveniencia de modular el nivel de protección del consumidor respecto al que se reconoce en condiciones normales, en atención a la necesidad de evitar consecuencias gravemente perjudiciales sobre los sectores empresariales implicados, v. GANUZA/GómEz PomAR, op. cit., p. 575. En un sentido más crítico, por la pérdida de derechos que puede suponer para los consumidores, y por la contradicción que implica respecto a lo dispuesto por las Directivas comunitarias en la materia, GARCíA RuBio, op. cit., pp. 38 y ss.

${ }^{14}$ Preceptos posteriormente modificados por Disp. Final 9a RDLey 26/2020, y por RDLey 37/2020, de 22 diciembre (art. 1). La Disp. Adic. $2^{\mathrm{a}}$ de este último prevé determinadas compensaciones a favor de los propietarios y arrendadores que se vean perjudicados por el posible retraso de las Administraciones Públicas en la adopción de las medidas de protección social procedentes respecto a los arrendatarios en situación de vulnerabilidad.

${ }^{15}$ A falta de acuerdo, la solución diseñada no consiste en imponer la moratoria con carácter obligatorio, sino en la habilitación de una línea de avales para la cobertura por el Estado de la financiación bancaria a arrendatarios en situación de vulnerabilidad como consecuencia de la crisis del coronavirus, o bien en facilitar la aplicación temporal de las fianzas arrendaticias para cubrir alguno de los periodos de renta aplazados.

${ }^{16}$ Posteriormente complementado por RDLey 35/2020, de 22 diciembre, en el que se regula (arts. 1 a 6 ) un procedimiento para que las partes puedan llegar a un acuerdo para la "modulación" del pago de las rentas de los alquileres de locales (modulación que puede concretarse, según los casos, en una reducción temporal de la renta o en una moratoria para su pago); y se prevén asimismo (art. 13) determinados incentivos fiscales para los arrendadores personas físicas de locales de negocio que acuerden determinadas rebajas voluntarias de las rentas.
} 
más coherente, según se dice, con la doctrina jurisprudencial sobre la cláusula rebus sic stantibus, en la medida en que se considera una vía más adecuada para buscar, a través del acuerdo entre las partes, un reequilibrio en las posiciones contractuales ${ }^{17}$.

13. El análisis crítico de buena parte de las normas apuntadas ha sido ya abordado en diferentes trabajos de investigación a los que nos permitimos remitir al lector ${ }^{18}$. En este momento, bastará con poner de manifiesto que, siendo tales medidas sin duda imprescindibles en las actuales circunstancias, no son pocas las justificadas críticas que se han venido planteando respecto a su concreta formulación. Se ha señalado, en este sentido, que se trata de normas técnicamente muy imperfectas, difíciles de interpretar y de aplicar, en ocasiones contradictorias, y casi siempre mal redactadas ${ }^{19}$. Desde el punto de vista de su finalidad, se echa de menos una técnica más cuidada a la hora de definir cuáles son los sectores económicos y sociales "vulnerables" a los que se pretende proteger en cada caso ${ }^{20}, \mathrm{y}$ también una mayor sensibilidad en el terreno de las exigencias administrativas y burocráticas a las que supedita el reconocimiento de tales situaciones de vulnerabilidad y la propia activación de las medidas ${ }^{21}$. Se echa de menos, igualmente, una mayor atención a la necesidad de adoptar medidas encaminadas a cortar de la manera más rápida y eficaz posible los problemas derivados de la falta de liquidez en la economía, evitando así posibles reacciones en cadena susceptibles de propagar a todos los sectores los negativos efectos de la crisis $^{22}$. En lo que se refiere, concretamente, a las medidas encaminadas a paliar las negativas consecuencias de la pandemia sobre las relaciones contractuales, se ha subrayado igualmente el hecho de que el legislador no siempre es consciente de la necesidad de incidir en la regulación de las relaciones entre

\footnotetext{
${ }^{17}$ Exposición de Motivos del RDLey 11/2020 (Ap. II): “Como consecuencia de las medidas excepcionales adoptadas por el Real Decreto 463/2020, de 14 de marzo, por el que se declara el estado de alarma para la gestión de la situación de crisis sanitaria ocasionada por el COVID-19, muchas actividades económicas se han visto obligadas a suspender su actividad o a reducir drásticamente la misma. En virtud de lo anterior, la falta de ingresos o la minoración de los mismos durante el periodo que dure el estado de alarma puede dar lugar a la incapacidad financiera de autónomos y pymes para hacer frente al cumplimiento, total o parcial, de sus obligaciones de pago de renta de locales en alquiler que pone en serio riesgo la continuidad de sus actividades. A falta de acuerdo entre las partes, la Ley 29/1994, de 24 de noviembre, de Arrendamientos Urbanos no prevé causa alguna de exclusión del pago de la renta por fuerza mayor o por declaración de estado de alarma u otras causas, salvo en lo referido en su artículo 26, relativo a la habitabilidad de la vivienda derivada de la ejecución de obras, que puede ser aplicable a los locales de negocio vía artículo 30 de esta Ley. Asimismo, si se acude a la regulación del Código Civil referida a la fuerza mayor, tampoco ofrece una solución idónea porque no ajusta la distribución del riesgo entre las partes, aunque puede justificar la resolución contractual en los casos más graves. Ante esta situación, procede prever una regulación especifica en línea con la cláusula "rebus sic stantibus", de elaboración jurisprudencial, que permite la modulación o modificación de las obligaciones contractuales si concurren los requisitos exigidos: imprevisibilidad e inevitabilidad del riesgo derivado, excesiva onerosidad de la prestación debida y buena fe contractual. Se considera conveniente ofrecer una respuesta que permita abordar esta situación y regular un procedimiento para que las partes puedan llegar a un acuerdo para la modulación del pago de las rentas de los alquileres de locales". Sobre la posibilidad de recurrir a la doctrina de la cláusula rebus sic stantibus más allá de los límites definidos por la legislación de emergencia en materia de arrendamientos de locales de negocio o de industria, v. Pantaleón Prieto, F., “Arrendamiento de local de negocio y suspensión legal de actividades empresariales", en Almacén de Derecho, 23 abril 2020, pp. 12-13, y García Rubio, op. cit., pp. 26-27; en contra, Bercovitz Rodríguez-Cano, R., "Incidencia del Real Decreto-Ley 15/2020 sobre los arrendamientos para uso distinto del de vivienda", en Grandes Tratados. Comentarios al Título III de la Ley de Arrendamientos Urbanos, ed. Aranzadi, 2020 (BIB. 2020/11085), p. 12.

${ }^{18}$ Entre los trabajos de alcance más general, v. los ya citados de Ganuza/Gómez Pomar, Morales Moreno, García Rubio, GÓMEZ LigüERRE y GREGORACI.

${ }^{19}$ Por todos, García Rubio, op. cit., pp. 17 y ss.

${ }^{20}$ García Rubio, op. cit., pp. 32 y ss.

${ }^{21}$ GanUZa/Gómez Pomar, op. cit., p. 562, donde se critica la insistencia del legislador en la imposición de exigencias de formalización, documentación o registro (p. ej., en materia de moratorias hipotecarias), y se postula la conveniencia de favorecer el control ex post sobre el control ex ante respecto al cumplimiento de los requisitos exigidos para la aplicación de las medidas. En el mismo sentido, García RuBio, op. cit., pp. 30-31, y p. 33, respecto a las exigencias relacionadas con la justificación documental de la situación de vulnerabilidad alegada.

${ }^{22}$ Ganuza/Gómez Pomar, op. cit., p. 563. En esta línea se sitúa Gregoraci (op. cit., pp. 474-475 y 484), cuando critica "que el legislador no haya procedido a desactivar de manera generalizada, durante el estado de alarma e incluso hasta algunos meses después de su finalización, la facultad de resolución, en general, y las cláusulas resolutorias en particular". Según la autora, una previsión de este tipo permitiría reducir el riesgo de que se produzcan resoluciones en cadena (con su negativo efecto sobre la liquidez de los sujetos afectados y sobre la preservación del entramado preexistente de contratos, fundamental para la futura reactivación de la economía), y supondría además un incentivo a la negociación entre las partes.
} 
particulares con técnicas distintas de las que son propias del ámbito administrativo, optando en ocasiones por redistribuir el riesgo económico entre las partes contractuales con arreglo a criterios discutibles, cuando no arbitrarios ${ }^{23}$.

14. Es evidente, en todo caso, que ni la legislación de emergencia dictada hasta el momento ni la que previsiblemente habrá de dictarse en los próximos meses (quizá años) podrá ofrecer una solución satisfactoria a todos los problemas y conflictos que se vienen planteando y seguirán surgiendo en el futuro inmediato. Inevitablemente, serán muchas las relaciones contractuales cuyo desarrollo normal habrá de verse negativamente influido por las consecuencias directas e indirectas de la pandemia, y cuya solución, con frecuencia, habrá de buscarse necesariamente en el ámbito judicial. Es en este terreno donde habrán de entrar en juego los conceptos de fuerza mayor/caso fortuito y excesiva onerosidad sobrevenida/rebus sic stantibus, a los que, por otra parte, se viene dedicando una amplia atención por parte de los estudiosos del Derecho en los últimos tiempos, especialmente a raíz de la crisis financiera de 2008. Como ya hemos adelantado, la nueva crisis que ahora se nos plantea, cuando todavía no habíamos acabado de superar las secuelas de la anterior, obligará a todos los operadores jurídicos a afinar la interpretación y aplicación de estos dos clásicos mecanismos a la luz de las exigencias planteadas por la realidad.

15. A la espera de que, una vez superado el actual periodo de crisis (y con la experiencia acumulada que resulta de la concatenación de dos crisis sucesivas de alcance mundial), el legislador español se decida a abordar una reforma en profundidad o, al menos, una actualización o modernización de nuestro Derecho general de obligaciones y contratos para incorporar a nuestro sistema algunas de las novedades que vienen siendo reclamadas por la doctrina -y anticipadas en buena medida por la jurisprudencia-, entendemos que los diversos operadores jurídicos podrán beneficiarse de los criterios desarrollados a partir de los Principios de Unidroit sobre los contratos comerciales internacionales. Con el presente trabajo pretendemos contribuir a esa labor de estudio analizando, desde la perspectiva del sistema español vigente, las propuestas que formula la ya referida Nota sobre la interpretación y aplicación de los Principios en el contexto de la situación generada por la pandemia.

\section{El desarrollo de la crisis en España}

16. Sin ánimo exhaustivo, y con objeto de contextualizar adecuadamente el análisis, parece imprescindible realizar una breve exposición acerca de la evolución que ha experimentado la crisis del coronavirus en España a lo largo de los últimos meses. Es bien sabido que, tras la aparición de los primeros casos de la enfermedad en China, y tras su extensión a algunos países de su entorno, Europa fue una de las primeras regiones en recibir con especial intensidad el impacto de la propagación. En un primer momento, fueron Italia y España los países europeos más afectados por la expansión de la enfermedad; en el caso concreto de España, el incremento descontrolado de los contagios a lo largo de los meses de febrero y marzo (del que pronto fue consciente la opinión pública española en general: ya el 12 de febrero se había producido, con gran repercusión en los medios de comunicación, la cancelación de un acontecimiento de relevancia internacional, como el Mobile World Congress de Barcelona ${ }^{24}$, y era conocida la preocupante progresión de la enfermedad en un país muy próximo a España en tantos aspectos como es Italia), y las negativas previsiones sobre la insoportable presión que ello había de suponer para el sistema sanitario, dieron lugar a que ya en una fecha relativamente temprana se adoptaran por las autoridades medidas especialmente restrictivas de la movilidad y de la actividad económica y social.

\footnotetext{
${ }^{23}$ García Rubio, op. cit., pp. 17-18, 26 y 35. Como señala Gómez Ligüerre (op. cit., p. 3), “el legislador debería ser consciente de que las medidas de protección del deudor de determinadas prestaciones alteran el equilibrio acordado por las partes del contrato en los términos en que fue pactado".

${ }^{24}$ La GSMA, asociación organizadora del Congreso -cuya celebración estaba prevista para los días 24 a 27 de febrero-, tomó la decisión definitiva de cancelar la edición de este año el día 12 de febrero, después de que varias de las empresas más relevantes del sector anunciaran que no acudirían al Congreso como medida de precaución ante la expansión de la enfermedad.
} 
Mediante la promulgación por el Gobierno nacional del Real Decreto 463/2020, de 14 de marzo (solo tres días después de que la OMS declarara la situación de pandemia mundial), se declaraba -con fundamento en el art. 116.2 de la Constitución y en la Ley Orgánica 4/1981, de 1 de junio- el estado de alarma en todo el territorio nacional, y se ordenaba de forma inmediata el confinamiento domiciliario general de la población, la cancelación de eventos públicos y el cese de prácticamente todas las actividades económicas no esenciales que implicaran desplazamientos de personas. De acuerdo con las previsiones constitucionales, el estado de alarma habría de ser posteriormente prorrogado hasta en seis ocasiones por el Congreso de los Diputados, finalizando el día 21 de junio de 2020; al mismo tiempo, se promulgaron numerosas disposiciones normativas (varias de ellas con rango de ley) encaminadas a regular diferentes aspectos de la actividad económica y social, incluyendo, como hemos visto, numerosas medidas sectoriales relacionadas directamente con el régimen de las relaciones contractuales entre particulares.

17. A medida que las cifras sanitarias iban manifestando una cierta mejoría, comenzó a plantearse la conveniencia de ir relajando paulatinamente las medidas de confinamiento y la paralización de la actividad económica. Tras la negativa del Congreso a conceder una nueva prórroga del estado de alarma, a partir de los primeros días de mayo se puso en marcha un proceso de "desescalada" articulado en cuatro fases, que, en función de las circunstancias de cada territorio, habría de finalizar a lo largo del mes de junio con el inicio de la fase denominada de "nueva normalidad" ${ }^{25}$. Con este planteamiento, se pretendía hacer coincidir con el periodo estival (en el que se confiaba en que se produjera una cierta ralentización en la propagación del virus) una recuperación general, aunque sujeta a ciertos límites, de la actividad económica y social, que habría de proyectarse, no solo en el ámbito interno español, sino también hacia el exterior, mediante la reactivación, al menos parcial, del sector turístico, esencial para la economía del país.

18. Lamentablemente, el desarrollo de los acontecimientos tras el desconfinamiento no se correspondió con las expectativas. Las esperanzas de poder controlar de manera rápida y eficaz los brotes más o menos esporádicos que pudieran detectarse durante la nueva fase se vieron pronto defraudadas. Los brotes se multiplicaron rápidamente, y pronto fueron dando paso, nuevamente, a situaciones de contagio comunitario; como consecuencia, la actividad turística durante los meses de julio y agosto descendió a cifras notablemente bajas. Llegado el mes de septiembre, y en vísperas de que se reiniciase la actividad escolar, era ya evidente que, con el inicio del otoño, la prevista segunda oleada de la epidemia llegaría a España sin que se hubiera conseguido controlar eficazmente la primera. Ya en octubre, comenzaron a adoptarse nuevas medidas restrictivas de la movilidad y de la actividad, primero a nivel local o comarcal, posteriormente a nivel regional ${ }^{26}, \mathrm{y}$, finalmente, a nivel nacional, con la declaración por el Gobierno nacional de un nuevo estado de alarma ${ }^{27}$. Durante el mes de noviembre, la mayor parte de las Comunidades Autónomas se mantuvieron en situación de cierre perimetral, muchas establecieron también el cierre perimetral de todos o parte de sus municipios, se ordenó el toque de queda general durante las horas nocturnas en todo el país, y se adoptaron, en diferentes territorios, medidas que suponían el cese total o parcial de actividad en determinados sectores económicos, como la hostelería. A medida que se aproximaba el fin del año, la constatación de una cierta estabilización en las cifras de contagios, unida al deseo de salvar en lo posible la campaña navideña, tanto desde el punto de vista económico como social, llevó a las autoridades a flexibilizar en alguna medida las restricciones; simultáneamente, comenzaban a concretarse las esperanzadoras noticias sobre la posibilidad de disponer, en un breve plazo, de una o varias vacunas eficaces para luchar contra la pandemia. Mientras se escriben estas líneas, en los primeros días de enero, la puesta en marcha del programa de vacunación universal coincide con

\footnotetext{
${ }^{25}$ Acuerdo del Consejo de Ministros de 28 de abril de 2020, por el que se aprueba el "Plan para la Transición hacia una Nueva Normalidad"; Real Decreto 555/2020, de 5 de junio; y RDLey 21/2020, de 9 de junio.

${ }^{26}$ Real Decreto 900/2020, de 9 de octubre, por el que se declaraba nuevamente el estado de alarma, en este caso con referencia a determinadas zonas de la Comunidad Autónoma de Madrid.

${ }^{27}$ Real Decreto 926/2020, de 25 de octubre, por el que se declara el estado de alarma para contener la propagación e infecciones causadas por el SARS-CoV-2, cuya vigencia prevista, tras la aprobación de la correspondiente prórroga por el Congreso, es de seis meses.
} 
la confirmación de las peores previsiones sobre la llegada de una tercera oleada de la pandemia, cuya envergadura podría superar a las anteriores, y con las especulaciones sobre la posibilidad y conveniencia de nuevos confinamientos. La incertidumbre sobre lo que habrá de suceder en los próximos meses, en definitiva, se mantiene.

\section{La fuerza mayor}

\section{El concepto de fuerza mayor en los Principios: la noción de "impedimento para el cumplimien- to" y la imposibilidad sobrevenida de la prestación}

19. El art. 7.1.7 de los Principios (ubicado dentro del Capítulo VII, dedicado al incumplimiento ${ }^{28}$ ) configura la fuerza mayor como un impedimento para el cumplimiento del contrato que, concurriendo determinados requisitos, exonera al deudor de responsabilidad por los daños derivados del incumplimiento. Si el impedimento es temporal, la exoneración solo produce efectos durante un "periodo razonable", suspendiendo mientras tanto el cumplimiento. En todo caso, la concurrencia de un supuesto de fuerza mayor no priva a las partes de la posibilidad de ejercitar otros derechos que les puedan corresponder conforme a otras normas, como el de resolver el contrato, suspender el cumplimiento de las propias obligaciones, o exigir intereses por las sumas debidas ${ }^{29}$. Según se indica en el Comentario oficial de los Principios ${ }^{30}$, se trata de un concepto de fuerza mayor que no se corresponde ni con la tradición del common law relativa a la doctrina de la "frustración e imposibilidad de cumplimiento", ni con la tradición continental de la force majeure, Unmöglichkeit, etc., sino que se toma de la práctica comercial internacional, donde es frecuente la inclusión en los contratos de las llamadas "cláusulas de force majeure"; lo que supone atribuir a la propia definición de la fuerza mayor un carácter "necesariamente amplio", dado que los contratos mercantiles internacionales establecen con frecuencia disposiciones más complejas y precisas al respecto ${ }^{31}$.

\footnotetext{
${ }^{28}$ Obsérvese que, mientras que la fuerza mayor se regula en el capítulo 7, dedicado al incumplimiento, la excesiva onerosidad sobrevenida se regula en el capítulo 6, dedicado al cumplimiento. El art. 7.1.7 de los Principios está inspirado en el art. 79 de la Convención de Naciones Unidas sobre los Contratos de Compraventa Internacional de Mercancías (Convenio de Viena), cuyo texto es el siguiente: "1) Una parte no será responsable de la falta de cumplimiento de cualquiera de sus obligaciones si prueba que esa falta de cumplimiento se debe a un impedimento ajeno a su voluntad y si no cabía razonablemente esperar que tuviese en cuenta el impedimento en el momento de la celebración del contrato, que lo evitase o superase, o que evitase o superase sus consecuencias. 2) Si la falta de cumplimiento de una de las partes se debe a la falta de cumplimiento de un tercero al que haya encargado la ejecución total o parcial del contrato, esa parte sólo quedará exonerada de responsabilidad: a) si está exonerada conforme al párrafo precedente, y b) si el tercero encargado de la ejecución también estaría exonerado en el caso de que se le aplicaran las disposiciones de ese párrafo. 3) La exoneración prevista en este artículo surtirá efecto mientras dure el impedimento. 4) La parte que no haya cumplido sus obligaciones deberá comunicar a la otra parte el impedimento y sus efectos sobre su capacidad para cumplirlas. Si la otra parte no recibiera la comunicación dentro de un plazo razonable después de que la parte que no haya cumplido tuviera o debiera haber tenido conocimiento del impedimento, esta última parte será responsable de los daños y perjuicios causados por esa falta de recepción. 5) Nada de lo dispuesto en este artículo impedirá a una u otra de las partes ejercer cualquier derecho distinto del derecho a exigir la indemnización de los daños y perjuicios conforme a la presente Convención". Un supuesto de aplicación del art. 79 de la Convención puede verse en la STS de 5 junio 2014 (RJ 4221).

${ }^{29}$ La influencia directa del art. 7.1.7 de los Principios es evidente en el modo de afrontar el tratamiento de las causas de exoneración del deudor en diferentes propuestas prelegislativas formuladas posteriormente en el ámbito jurídico europeo: v., p. ej., el art. 8.108 de los Principles of European Contract Law, o el art. III. - 3:104 del Draft of Common Frame of Reference. En el caso de España, esa misma influencia es claramente perceptible, p. ej., en el art. 1209 de la Propuesta para la Modernización del Derecho de obligaciones y contratos formulada por la Comisión General de Codificación en 2009 (disponible en https://www. mjusticia.gob.es/cs/Satellite/Portal/1292430960594?blobheader=application\%2Fpdf\&blobheadername1=Content-Dispositio n\&blobheadername $2=$ Grupo\&blobheadervalue $1=$ attachment\%3B+filename\%3DPropuesta_para_la_modernizacion_del_Derecho_de_obligaciones_y_contratos._Ano_2009.PDF\&blobheadervalue2=Docs_CGC_Propuestas), o o en el art. 518-24 de la Propuesta de Código Civil elaborada en 2018 por la Asociación de Profesores de Derecho Civil (disponible en http://www. derechocivil.net/images/libros/obra_completa.pdf).

${ }^{30}$ Principios Unidroit sobre los contratos comerciales internacionales, 2016, ed. Unidroit, Roma, 2016 (disponibles en https://www.unidroit.org/english/principles/contracts/principles2016/principles2016-e.pdf), p. 240. En adelante, Comentario. V. también ap. 13 de la Nota.

${ }^{31}$ Comentario, cit., p. 242.
} 
20. Como subraya la $N_{o t a}{ }^{32}$, el art. 7.1.7 se aparta de otras concepciones más tradicionales de la fuerza mayor, en la medida en que esta se identifica con un impedimento (total o parcial, definitivo o solo temporal) para el cumplimiento del contrato, pero no presupone necesariamente la imposibilidad sobrevenida de la obligación ${ }^{33}$ o la frustración definitiva de la finalidad del contrato. La noción de "impedimento" permite así al deudor recurrir a la fuerza mayor "incluso cuando una cierta forma de cumplimiento es todavía técnicamente posible, pero el impedimento cumple los estrictos requisitos enunciados en la disposición" ${ }^{34}$. En todo caso, se insiste ${ }^{35}$, el deudor deberá probar que la existencia del obstáculo es relevante para el cumplimiento, así como la relación causal entre obstáculo e incumplimiento.

21. De este modo, el instrumento de la fuerza mayor adquiere en los Principios una considerable flexibilidad aplicativa, que se manifiesta en diferentes aspectos. Así, p. ej., facilita la extensión de la eficacia exoneratoria de la fuerza mayor a supuestos en que, no habiendo en sentido estricto imposibilidad de cumplimiento, este solo puede realizarse de forma parcial, irregular o tardía; y permite asimismo aplicar dicho régimen a prácticamente cualquier tipo de obligación, incluso aquellas (como las genéricas) respecto de las cuales se ha considerado tradicionalmente (genus numquam perit) que, por su propia naturaleza, no pueden llegar a ser de imposible cumplimiento. Como veremos, los Principios solo parecen excluir la posibilidad de reconocer eficacia exoneratoria a la fuerza mayor impeditiva respecto a las obligaciones de dinero ${ }^{36}$. Desde otro punto de vista, el planteamiento flexible de los Principios permite mantener el principio de obligatoriedad de los contratos dentro de unos límites razonables y ajustados a las exigencias impuestas por la realidad y la buena fe, en la medida en que facilita la aplicación del régimen de la fuerza mayor en supuestos en que el cumplimiento de la obligación, siendo objetivamente posible, supondría un esfuerzo desproporcionado o económicamente ineficiente para el deudor; lo que, por otra parte, permite establecer una cierta continuidad (o incluso superposición) entre el régimen de la fuerza mayor y el de la excesiva onerosidad sobrevenida (tal como acertadamente destaca la Nota $^{37}$ ), evitando así los inconvenientes que pueden derivarse de la necesidad de establecer una nítida distinción entre dos conceptos -imposibilidad sobrevenida y excesiva onerosidad sobrevenida- que, en la práctica, no siempre será posible diferenciar con claridad ${ }^{38}$.

\footnotetext{
${ }^{32}$ Nota, cit., aps. 9 y 15.

${ }^{33}$ A la imposibilidad de la prestación se refiere el art. 7.2.2 de los Principios, no como causa de extinción de la obligación, sino como límite al derecho a reclamar el cumplimiento en forma específica de las obligaciones no dinerarias: "(Cumplimiento de obligaciones no dinerarias) Si una parte no cumple una obligación distinta a la de pagar una suma de dinero, la otra parte puede reclamar la prestación, a menos que: (a) tal prestación sea jurídica o físicamente imposible; (b) la prestación o, en su caso, la ejecución forzosa, sea excesivamente gravosa u onerosa (...)”.

${ }^{34}$ Nota, cit., ap. 9.

${ }^{35}$ Nota, cit., ap. 15.

${ }^{36}$ V. infra, II.6.

${ }^{37}$ Nota, cit., aps. 50 y 51. En el Comentario (cit., p. 222) ya se señalaba: “A la vista de las definiciones de hardship, contenida en este artículo (6.2.2), y de fuerza mayor, contenida en el art. 7.1.7, conforme a los Principios pueden darse situaciones fácticas que puedan al mismo tiempo ser consideradas como casos de excesiva onerosidad sobrevenida y de fuerza mayor. Si es este el caso, corresponde a la parte afectada por tales sucesos decidir qué remedio utilizar. Si invoca fuerza mayor, será con objeto de excusar su falta de cumplimiento. Si, por el contrario, una parte invoca la excesiva onerosidad sobrevenida, ello ocurrirá en primer término con el propósito de renegociar los términos del contrato, con objeto de conseguir que este se mantenga en vigor, aunque con sus términos revisados".

${ }^{38}$ A esta cuestión se refiere, para el sistema español, Carrasco Perera (Derecho de contratos, $2^{\mathrm{a}}$ ed., ed. Thomson Reuters Aranzadi, Cizur Menor, 2017, pp. 971-972), cuando, tras señalar que, en principio, las circunstancias sobrevenidas que pueden fundamentar la aplicación de la doctrina de la cláusula rebus sic stantibus no pueden caracterizarse como caso fortuito exoneratorio, al no producir la imposibilidad de cumplimiento de la obligación de que se trata, añade: "En no pocas ocasiones, empero, la distinción entre una modificación sobrevenida extraordinaria y una imposibilidad sobrevenida no es fácil de trazar, explicándose de esta forma lo común que es la alegación conjunta e indistinta de ambas formas de exoneración. Lo mismo ocurre en casos extremos de fracaso de la presuposición contractual, donde la intercambiabilidad entre doctrina del error, de la desaparición de la causa y de la regla rebus es inevitable. La combinación entre imposibilidad y rebus puede ocurrir también porque una imposibilidad temporal haya retardado tanto el cumplimiento del contrato que su reanudación comportara para el deudor la necesidad de invertir un sobrecoste irrazonable por causa del tiempo transcurrido. No hay que dar excesiva importancia a estos solapamientos, ni tampoco al déficit teórico que en último extremo comporta la disponibilidad de diversos expedientes teóricos para explicar la misma cosa, siempre que se tengan claras las reglas reales de reparto de riesgos imprevisibles".
} 
22. En una primera aproximación, el sistema del CC español podría considerarse como un ejemplo de aquellos ordenamientos en los que la eficacia exoneradora de la fuerza mayor o del caso fortuito (reconocida genéricamente por el art. 1105) (39 $^{39}$ aparece vinculada a la imposibilidad sobrevenida de la prestación por causa no imputable al deudor, regulada entre las causas de extinción de la obligación en los arts. 1182 y ss. del citado cuerpo lega ${ }^{40}$. Y es cierto que, a la hora de interpretar y aplicar estos últimos preceptos (con frecuencia citados en conjunción con el art. 1105), la jurisprudencia española ha afirmado que la extinción de la obligación por imposibilidad sobrevenida, y la consiguiente liberación del deudor, ha de ser objeto de una interpretación restrictiva y casuística, atendiendo a las circunstancias; y que debe tratarse de una imposibilidad física o legal, objetiva, absoluta, duradera, y no imputable al deudor ${ }^{41}$.

23. Lo cierto, sin embargo, es que una lectura más detenida del texto legal y de la propia jurisprudencia permiten apreciar una mayor flexibilidad en el sistema español, en una línea, probablemente, no tan alejada de los Principios. Obsérvese, ante todo, que si bien el caso fortuito está presente (sea implícita o explícitamente) tanto en el art. 1105 como en los arts. 1182 y ss., la función que se asigna a dicha noción en uno y otro lugar no es la misma: en el art. 1105, el caso fortuito exonera al deudor de las consecuencias de la falta de un exacto cumplimiento, con independencia de que la obligación sea o no, todavía, de posible cumplimiento; mientras que en los arts. 1182 y ss. lo que se regula es la extinción de la obligación, y la consiguiente liberación del deudor (sin perjuicio de la atribución al acreedor del commodum representationis del art. 1186), en aquellos casos en que el cumplimiento de la prestación debida se haya hecho imposible por causa que no le sea imputable: es decir, por caso fortuito ${ }^{42}$. No sería correcto, en consecuencia, deducir que en el sistema español la eficacia exoneradora del caso fortuito presupone necesariamente la imposibilidad sobrevenida de la obligación ${ }^{43}$.

\footnotetext{
${ }^{39}$ Aunque es cierto que ha existido un debate tradicional y diferentes propuestas encaminadas a identificar algún criterio de distinción entre los conceptos de caso fortuito y fuerza mayor (v. una exposición más bien didáctica sobre el tema en la STS de 30 septiembre 1983, $R J 4688$ ), en la jurisprudencia se tiende a reconocer que, al menos en el ámbito de la responsabilidad contractual, se trata de términos sinónimos (v., p. ej., SSTS de 10 diciembre 1963, $R J 5220,8$ julio 1988, RJ 5584, 5 noviembre 1993, $R J$ 8970, 31 julio 1996, $R J$ 6084, y 19 mayo 2015, RJ 3118). De hecho, el propio CC utiliza ambos conceptos, en general, de forma indistinta (v., p. ej., los arts. 457, 1096.3, 1129.3으. 1136.2.1 ${ }^{\mathrm{a}}, 1183,1488,1744,1745,1777,1891$ y 1896.2). La posibilidad de establecer algún matiz diferencial parece apuntarse, sin demasiada claridad, en los arts. 1602, 1625 y 1784 CC; aunque, respecto a este último, alguna jurisprudencia sí ha subrayado la necesidad de distinguir entre caso fortuito y fuerza mayor en función de que el suceso alegado se sitúe dentro o fuera de la esfera de control del empresario hostelero (cfr. SSTS de 11 julio 1989, RJ 5598, 15 marzo 1990, RJ 1696, y 27 enero 1994, RJ 569); en la doctrina, por todos, BAdosa Coll, F., “Artículo 1105”, en PAZ-ARES Rodríguez y otros (dir.), Comentario del Código Civil, Ministerio de Justicia, 1991, t. II, p. 43; y Asúa GonzÁlez, C., "Artículo 1105”, en Bercovitz Rodríguez-Cano, R. (dir.), Comentarios al Código Civil, t. VI, ed. Tirant lo Blanch, Valencia, 2013, p. 8.100 , donde señala que, al margen de supuestos específicos como los señalados, y, en particular, en el ámbito del art. 1105, ambos términos pueden usarse indistintamente. Con referencia concreta a la actual situación, señala GREGORACI (op. cit., p. 459, n. 4): "Hasta donde llega mi conocimiento, en el contexto del COVID-19 no se ha planteado la discusión relativa a distinción entre caso fortuito y fuerza mayor, probablemente porque una construcción objetiva del caso fortuito, entendido como suceso externo a la esfera de control del deudor, difumina la diferencia entre ambas figuras en el ámbito de la responsabilidad contractual".

${ }^{40}$ Concretamente, el art. 1182 declara extinguida la obligación de entregar cosa determinada cuando esta se pierda o destruya sin culpa del deudor y antes de haberse constituido este en mora; mientras que el art. 1184 establece que también quedará liberado el deudor en las obligaciones de hacer cuando la prestación resultare legal o físicamente imposible. La vinculación entre la fuerza mayor del art. 1105 y la imposibilidad sobrevenida del art. 1184 se hace explícita, p. ej., en las SSTS de 19 junio 2014 (RJ 3778), 20 julio 2017 (RJ 3653) y 26 abril 2018 (RJ 2192). En la doctrina, esta vinculación fue defendida especialmente por Jordano Fraga (La responsabilidad contractual, ed. Civitas, Madrid, 1987, pp. 197 y ss.), para quien el hecho exoneratorio de la responsabilidad contractual en el CC es un hecho exoneratorio-extintivo complejo, compuesto por dos elementos: la imposibilidad sobrevenida de la prestación, y la no imputabilidad al deudor de la causa que la origina.

${ }^{41}$ Una buena síntesis de la doctrina jurisprudencial sobre la imposibilidad sobrevenida de los arts. 1182 y ss. puede verse en la STS de 30 abril 2002 ( $R J$ 4041), que a su vez cita otras muchas. Más recientemente, STS 13 mayo 2008 (RJ 3061).

${ }^{42}$ En este sentido, PAntaleón Prieto, F., "El sistema de responsabilidad contractual (materiales para un debate)", en $A D C$, 1991, t. XLIV, pp. 1.019 a 1.092, p. 1.044; y CARRASCO (Derecho de contratos ..., cit., p. 955), para quien, en el art. 1105, el caso fortuito exonera de los daños causados a un interés de indemnidad del acreedor, con independencia de que la obligación pueda o no ser cumplida; mientras que, en el ámbito de los arts. 1182 y ss., no se trata tanto de determinar si el deudor debe responder por los daños, sino si sigue o no obligado a cumplir. En el mismo sentido, MARín LóPEZ, M.J., "Artículos 1182 a 1186 ", en Bercovitz Rodríguez-Cano, R. (dir.), Comentarios al Código Civil, t. VI, ed. Tirant lo Blanch, Valencia, 2013, p. 8.709.

${ }^{43}$ De hecho, algún sector doctrinal ha defendido la posibilidad de establecer una distinción entre el caso fortuito exoneratorio del art. 1105 (entendido como suceso que excede de la diligencia máxima, más allá incluso de la exigible concretamente
} 
24. Hay que recordar, por otra parte, que el propio concepto de "imposibilidad sobrevenida de la prestación" viene siendo interpretado por la jurisprudencia en un sentido bastante amplio. Por un lado, se admite sin discusión que la imposibilidad puede ser tanto física como legal, no solo en el caso de las obligaciones de hacer (a las que se refiere directamente el art. 1184), sino también en las de dar cosa específica, pese que el art. 1182 únicamente contempla, respecto a ellas, los supuestos de pérdida o destrucción; de manera que también quedará liberado el deudor en los casos en que sea imposible entregar la cosa debida por causas legales o fácticas ${ }^{44}$. Además, junto a la imposibilidad legal y física se ha llegado a reconocer la virtualidad extintiva de la llamada "imposibilidad económica", que se daría en aquellos casos en que, por circunstancias sobrevenidas, alguna de las prestaciones deja de producir ningún beneficio a la parte que debería recibirla, lo que sitúa el supuesto en un ámbito próximo a la desaparición sobrevenida de la causa o a la frustración del fin del contrato ${ }^{45}$.

25. Desde otro punto de vista, se reconoce habitualmente que, siendo todavía posible el cumplimiento de la obligación, la concurrencia de un supuesto de caso fortuito impeditivo también exonera de responsabilidad, sin liberarle de su obligación, al deudor que solo puede cumplir de forma tardía, parcial o irregular ${ }^{46} ; \mathrm{y}$, de hecho, este planteamiento se ha llegado a aplicar incluso en el caso de obligaciones genéricas cuyo cumplimiento se ve dificultado, pero no imposibilitado, por un supuesto de fuerza mayor $^{47}$. En los casos de imposibilidad sobrevenida meramente parcial, se admite la subsistencia parcial

al deudor conforme al art. 1104), y el caso fortuito liberatorio del art. 1182 (entendido como ausencia de culpa-hecho propio del deudor); en este sentido, BADOSA, “Artículos 1094 a 1105" y "Artículos 1182 a 1186", en Comentario..., cit., pp. 43 y 258; y, siguiendo al anterior, De Pablo Contreras, P., "Incumplimiento de las obligaciones y responsabilidad contractual”, en Martínez de Aguirre y Aldaz, C. (coord.), Curso de Derecho Civil (II). Volumen I. Teoría general de la obligación y el contrato, ed. Edisofer, $5^{\text {a }}$ ed., Madrid, 2018, pp. 179 y 190. Un detenido estudio de la noción de caso fortuito en el sistema español de responsabilidad contractual, con referencias a las diferentes interpretaciones doctrinales, puede verse en GiL RodRíGUEZ, J., "Responsabilidad por incumplimiento", en PUIG I Ferriol, Ll. y otros, Manual de Derecho Civil. II. Derecho de obligaciones. Responsabilidad civil. Teoría general del contrato, ed. Marcial Pons, Madrid, 1996, pp. 299 y ss.

${ }^{44}$ V., p. ej., SSTS de 30 noviembre 2006 (RJ 2007/241), 17 enero 2013 (RJ 1819), 19 mayo 2015 (RJ 3118), y 20 julio 2017, (RJ 3653), que citan otras muchas. En la doctrina, por todos, MARín López, op. cit., p. 8.705. De este modo, se entiende que el deudor se libera, no solo cuando la cosa debida se pierde o destruye físicamente, o cuando se da una dificultad extraordinaria para encontrarla o recuperarla, sino también, p. ej., cuando la cosa no puede ser entregada por estar en poder de un tercero protegido, o por haber quedado fuera del comercio de forma sobrevenida (cfr. art. 1122.2 ). Recuerda la STS de 30 abril 2002 ( $R J$ 4041), con cita de otras muchas, que la imposibilidad sobrevenida de carácter legal abarca la derivada de un texto legal, pero también la que procede de preceptos reglamentarios, mandatos de autoridad competente, y otras causas jurídicas. En el mismo sentido, SSTS de 15 diciembre 1987 ( $R J$ 9434), 26 abril 2018 ( $R J 2192)$, y 7 febrero 1994 ( $R J 917$ ); en esta última se advierte que no le es exigible al deudor que recurra las disposiciones de la autoridad que impidan el cumplimiento del contrato.

${ }^{45}$ Maneja el concepto de "imposibilidad económica" la conocida STS de 20 abril 1994 (RJ 3216) (relativa al arrendamiento de una finca para la explotación del guijo existente en la misma, que posteriormente resultó ser económicamente inviable) en la que, aludiendo también a la doctrina de la desaparición sobrevenida de la causa y a la frustración del fin del contrato, se señalaba: "El motivo se estima por haber desaparecido la causa negocial durante el transcurso de la vigencia del contrato de tracto sucesivo. Siendo la causa la finalidad común perseguida por los contratantes, cuando la misma no se mantiene durante el tiempo de duración de la relación contractual en virtud de acontecimientos imprevisibles para las partes en el momento de su perfección, no puede sostenerse jurídicamente el entramado de derechos y obligaciones que forman su contenido so pena de autorizar enriquecimientos a todas luces injustificados. No es que haya que moderar equitativamente el contrato, dejándolo subsistente, en virtud de la doctrina de la cláusula 'rebus sic stantibus', porque carece de sentido que, si la prestación de una de las partes se ha hecho imposible, la otra tenga que cumplir la suya aun de forma más reducida. Tal doctrina sólo es aplicable en caso de notorio desequilibrio entre las prestaciones, no en caso de ausencia de una de ellas. La imposibilidad de la prestación no sólo puede ser física o legal, sino económica, como cuando no produce ningún beneficio al que ha de recibirla, o cuando, como ocurre en el caso litigioso, es totalmente ruinosa para él recibirla. Existe entonces una frustración del fin del contrato, que impide jurídicamente su mantenimiento y faculta para resolverlo". También en la doctrina se ha sostenido que, en aquellos casos en que, no siendo imposible en sí misma la prestación, esta no puede ya satisfacer de ningún modo el interés del acreedor, cabría entender que aquella se extingue por imposibilidad para cumplir el fin que le es propio; en este sentido, $\mathrm{p}$. ej., Marín López, op. cit., p. 8.716; y CARRASCO, Derecho de contratos, cit., pp. 947-948.v

${ }^{46}$ V., p. ej., SSTS de 3 julio 1992 ( $R J 6046$ ) y 1 junio 1996 ( $\left.R J 4716\right)$, que recuerdan que no es mora el simple retraso en el cumplimiento, sino que se requiere, entre otras cosas, un retraso culpable (al menos, a efectos indemnizatorios).

${ }^{47}$ V., p. ej., la STS de 13 junio 1944 (RJ 893), relativa a la entrega de unas partidas de aceite que se vio afectada por la guerra civil: "La fuerza mayor dimanante de la guerra, operando en las obligaciones genéricas por ella afectadas, no produce en principio efecto extintivo por imposibilidad absoluta y permanente de cumplimiento, en atención a que el género no perece, pero produce corrientemente imposibilidad pasajera con efectos meramente suspensivos en aquellos casos en que la fecha de 
de la obligación en la medida en que esta siga teniendo interés para el acreedor ${ }^{48}$. En algunos supuestos, la propia ley opta por imponer al deudor, imposibilitado para cumplir en los términos inicialmente previstos, la obligación de buscar formas alternativas de cumplimiento susceptibles de satisfacer el interés del acreedor o, al menos, de paliar el perjuicio sufrido por este ${ }^{49}$; obligación que, a falta de una expresa previsión legal, se considera que puede hacerse derivar también de la correcta interpretación del contrato conforme a la buena fe (arts. 7.1 y $1258 \mathrm{CC}$ y art. $57 \mathrm{Ccom}$.) ${ }^{50}$.

26. Por otra parte, aun partiendo de la base de que no puede identificarse con la imposibilidad la mera dificultad para cumplir en la que pueda encontrarse el deudor ${ }^{51}$, la jurisprudencia española, argumentando que el principio de buena fe y la prohibición del abuso de derecho pueden imponer ciertos límites a la exigibilidad del cumplimiento por parte del acreedor en atención a las circunstancias, ha llegado a reconducir al ámbito de la imposibilidad sobrevenida los supuestos de la llamada "dificultad extraordinaria o exorbitante", es decir "aquella que exigiría vencer dificultades que puedan ser equiparadas a la imposibilidad, por exigir sacrificios absolutamente desproporcionados o violación de deberes más altos"; en tal caso, se dice, el incumplimiento no será imputable al deudor, y este quedará liberado de su obligación, si procedió conforme a la diligencia que las circunstancias requerían, con arreglo al art. $1104^{52}$. Más allá de los límites señalados, cuando el cumplimiento del contrato en sus propios términos sea todavía posible, pero resulte excesivamente gravoso para una de las partes, podrá recurrirse, en su caso, a la doctrina jurisprudencial sobre la cláusula rebus sic stantibus por cambio sobrevenido de las circunstancias ${ }^{53}$; doctrina que, por otra parte, y a diferencia de lo que sucede con el

la entrega es requisito accidental constitutivo de simple demora amparada con efectos liberatorios por la fuerza mayor, y no entra en juego como elemento esencial y determinante del contrato, como entraría en obligaciones a fecha fija, en las que la prestación a destiempo contraría sustancialmente el fin perseguido y anula o resuelve la obligación en cuanto a su cumplimiento 'in natura'”. En las SSTS (Contencioso-Administrativo) de 28 febrero 1951 (RJ 554) y 26 junio 1954 (RJ 2372) llegó a admitirse la extinción por imposibilidad sobrevenida debida a fuerza mayor de determinadas obligaciones genéricas, cuyo cumplimiento se había visto impedido por la guerra civil (incautaciones de una partida de trigo en la guerra civil).

${ }^{48}$ V., p. ej., STS de 12 marzo 1994 (RJ 1742), relativa a una obligación de rendir cuentas cuyo cumplimiento se había hecho parcialmente (pero no totalmente) imposible como consecuencia del fallecimiento del administrador, lo que permite entender que la obligación subsistía, aunque modificada, a cargo de sus herederos.

${ }^{49}$ Sobre el tema, v. CARRASCo, Derecho de contratos..., cit., pp. 957 y 961 que cita como ejemplo los deberes de salvamento $\mathrm{y}$ asistencia al viajero que se imponen al transportista y al organizador de viajes combinados en los arts. 657 Ccom. y 161.2 y 162.2 TRLGDCU. En el propio CC, v., p. ej., art. 798, relativo al cumplimiento por analogía del modo testamentario.

${ }^{50}$ Carrasco, Derecho de contratos..., cit., p. 960. La STS de 30 abril 2002 (RJ 4041), citando las de 22 febrero 1979 (RJ 523) y 11 noviembre 1987 ( $R J$ 8372), dispone que "no cabe alegar imposibilidad cuando es posible cumplir mediante la modificación racional del contenido de la prestación de modo que resulte adecuado a la finalidad perseguida".

${ }^{51}$ SSTS de 17 mayo 1957 (RJ 2164), 6 abril 1979 (RJ 1272), 11 noviembre 1995 (RJ 8119), y 28 noviembre 1997 (RJ 8431).

${ }_{52}$ P. ej., SSTS de 9 noviembre 1949 (RJ 1245), 30 septiembre 1983 ( $\left.R J 4688\right), 6$ mayo 1994, (RJ 3888) y 21 abril 2006 $(R J 1875)$.

${ }^{53} \mathrm{La}$ oportunidad de reconducir al ámbito de la imposibilidad sobrevenida o del caso fortuito liberatorio supuestos como los señalados ha sido cuestionada por diferentes autores, que consideran más adecuado recurrir a otros expedientes. Así, p. ej., CARRASCO (en Derecho de contratos..., cit., p. 947) afirma que no hay caso fortuito, pero sí liberación del deudor cuando la pretensión de cumplimiento del acreedor implica un abuso de derecho subjetivo, lo que sucede cuando, por circunstancias sobrevenidas, el coste de cumplimiento para el deudor deviene exorbitante, o la utilidad de cumplimiento para el acreedor se reduce sustancialmente; y tampoco cuando, por circunstancias sobrevenidas y no buscadas por el deudor, el deber de cumplimiento deviene inexigible porque ello supondría poner en peligro derechos, intereses o valores superiores. Para MARín LóPEZ (op. cit., pp. 8.707-8.708), la dificultad en el cumplimiento o la superveniencia de circunstancias que agravan considerablemente el coste de cumplimiento no son casos de imposibilidad sobrevenida liberatoria, a menos que para vencerlas el deudor haya de realizar una actividad ilícita, o sacrificar su integridad personal u otros atributos de la personalidad; al margen de estos casos, el deudor solo podrá obtener la modificación del contrato o su resolución acudiendo a la doctrina de la cláusula rebus sic stantibus. Para Gómez LigüErRe (op. cit., p. 6), "el requisito de la culpa ha llevado a nuestros jueces y tribunales a ampliar los ámbitos de lo imposible y de lo inevitable, que con demasiada frecuencia han sido aplicados a circunstancias de imposibilidad o dificultad relativas o meramente subjetivas. Algo que se aleja de, al menos, el tenor literal de los preceptos referidos". El mismo autor advierte (op. cit., pp. 9-10) sobre el problema que puede plantear la aplicación del régimen de la imposibilidad liberatoria o exoneratoria a supuestos que son más bien de excesiva onerosidad sobrevenida, en la medida en que ello puede dificultar la subsistencia de las relaciones contractuales. Por su parte, De PABLo (op. cit., p. 178) considera que, sin perjuicio de que el deudor pueda acudir a otras soluciones en caso de que la prestación se haga muy gravosa para él, la dificultad para cumplir, por grande que esta sea, no implica imposibilidad ni, por tanto, extingue la obligación; aunque, llegado el caso, sí podría justificar la exoneración de responsabilidad del deudor diligente conforme a los arts. 1104 y 1105. 
régimen de la imposibilidad sobrevenida por caso fortuito, sí podría llegar a ser aplicable a las obligaciones pecuniarias ${ }^{54}$.

27. Se confirma, por tanto, que en el sistema español las nociones de fuerza mayor o caso fortuito no siempre aparecen estrictamente vinculadas a la imposibilidad sobrevenida de la obligación, sino que pueden extender su eficacia exoneratoria a aquellos casos en que el cumplimiento, siendo todavía posible, se vea impedido, retrasado o dificultado por una causa sobrevenida no imputable al deudor. A los efectos que ahora interesan, por consiguiente, tanto la propia enfermedad, como las medidas adoptadas para combatirla, $\mathrm{o}$, en su caso, las consecuencias económicas derivadas, podrán ser consideradas, según los casos, como eventos de fuerza mayor susceptibles de exonerar de responsabilidad al deudor ante la falta de un cumplimiento exacto, o incluso de liberarle total o parcialmente, y temporal o definitivamente, de su obligación, sin necesidad de que pueda apreciarse una imposibilidad absoluta para cumplir, siempre que, a tenor de las circunstancias del caso concreto, concurran los demás requisitos legalmente exigidos ${ }^{55}$.

\section{El régimen de la imposibilidad originaria de la prestación en los Principios y en el CC.}

28. Aunque la Nota no se refiere a esta cuestión, interesa destacar que, en el sistema de los Principios, la imposibilidad originaria de la prestación no se configura como una posible causa de nulidad del contrato: según el art. 3.1.3 (1), "no afectará a la validez del contrato el mero hecho de que al momento de su celebración fuese imposible el cumplimiento de la obligación contraída". En el Comentario ${ }^{56} \mathrm{se}$ explica que se trata de una decisión conscientemente orientada a apartarse de la opción por la nulidad contractual acogida por numerosos sistemas jurídicos, siguiendo la tendencia más moderna a equiparar los efectos de la imposibilidad originaria con los de la imposibilidad sobrevenida, es decir, aplicando en tales supuestos el régimen del incumplimiento, lo que permitiría tener en cuenta, p. ej., el hecho de que la imposibilidad de cumplir fuera conocida por alguna de las partes en el momento de la celebración del contrato. Se señala también que, con esta solución, se despejan las dudas sobre la validez del contrato que tenga por objeto la entrega de cosas futuras; y se advierte que, en el caso de que la imposibilidad originaria sea consecuencia de una prohibición legal (p. ej., una prohibición de exportación o importación), "la validez del contrato dependerá de si, conforme al derecho bajo el cual se ha dictado la prohibición, ésta tiene el propósito de invalidar o simplemente de impedir el cumplimiento del contrato".

29. En el CC la imposibilidad originaria de la prestación se configura, en principio, y conforme a la concepción tradicional, como una circunstancia que impide el nacimiento de la obligación y da lugar a la nulidad del contrato (cfr. art. $1272^{57}$ en conexión con el 1261, en el que se incluye el "objeto cierto que sea materia del contrato" entre los requisitos esenciales para la existencia y validez del contrato; v. también art. 1460.1) $)^{58}$. A estos efectos, se considera indiferente que la imposibilidad originaria sea de hecho o de derecho (p. ej., existencia de una prohibición legal), aunque en este segundo caso puede plantearse también un problema de ilicitud de la prestación, igualmente determinante de la nulidad del contrato (art. 1271) $)^{59}$.

30. La aplicación de la distinción entre imposibilidad originaria y sobrevenida en el contexto de la crisis generada por el coronavirus podría resultar relevante en función de que la circunstancia impeditiva del cumplimiento (p. ej., la concreta medida que impide el cumplimiento) se diera ya en el

\footnotetext{
${ }^{54}$ STS de 19 mayo 2015 (RJ 3118).

${ }_{55}^{55}$ V. infra, II.3 y 4.

${ }^{56}$ Comentario, cit., pp. $97-98$.

${ }^{57}$ Art. 1272: "No podrán ser objeto de contrato las cosas o servicios imposibles".

${ }^{58}$ En la jurisprudencia, v. STS de 3 abril $2009(R J 1755)$ y las que en ella se citan.

${ }^{59}$ García Vicente, J.R., “Artículos 1271 y 1272”, en Bercovitz Rodríguez-Cano, R. (dir.), Comentarios al Código Civil, t. VII, ed. Tirant lo Blanch, Valencia, 2013, p. 9.137.
} 
momento de celebrarse el contrato, o hubiera sobrevenido con posterioridad a este. La cuestión no se planteará, lógicamente, respecto a los contratos celebrados antes de que se declarase la pandemia y se adoptasen las medidas correspondientes; pero sí podría suscitarse respecto a los contratos celebrados con posterioridad a ese momento.

31. Lo cierto, sin embargo, es que las diferencias teóricas entre el planteamiento del CC y el de los Principios en este punto se han visto en buena medida superadas en los análisis doctrinales y en la práctica jurisprudencial por una más correcta interpretación de las normas y de los remedios ofrecidos por estas. Ninguna duda plantea, obviamente, la validez del contrato que tenga por objeto cosas futuras (reconocida expresamente por el art. 1271.1), incluyendo, p. ej., aquellas que hayan de ser fabricadas o producidas por una de las partes. Tampoco se discute en el sistema español la validez del contrato por el que un sujeto se compromete a transmitir un bien o un derecho respecto del cual carece, al tiempo de la celebración del contrato, de la titularidad o de la facultad de disposición (lo que coincide con lo previsto en el art. 3.1.3 (2) de los Principios), por lo que, en su caso, lo procedente será aplicar el régimen del incumplimiento ${ }^{60}$. Naturalmente, no tiene por qué afectar a la validez del contrato el hecho de que al tiempo de su celebración el deudor esté imposibilitado para realizar personalmente la prestación cuando, teniendo en cuenta la propia naturaleza de esta, quepa la posibilidad de recurrir al cumplimiento por tercero (p. ej., cuando alguien se obliga a proporcionar al acreedor una cosa ajena o a realizar un servicio no personalísimo); en tales supuestos, solo cabría hablar de una imposibilidad relativa, no impeditiva $a$ priori del cumplimiento de la obligación, por lo que carecería de sentido aplicar el régimen de la invalidez y no el del incumplimiento. En ciertos supuestos de imposibilidad originaria pero meramente parcial, la propia ley reconoce al acreedor la posibilidad de aceptar la subsistencia parcial de la obligación, en su caso con una reducción proporcional de la contraprestación pactada (arts. 1460 $0^{61}$, 1469, 1471, a propósito de la compraventa). Tampoco hay motivos para excluir la validez de aquellos contratos que recaigan sobre prestaciones imposibles al tiempo de su celebración, cuando las partes, conociendo tal circunstancia, hayan previsto la eventualidad de que lleguen a ser posibles en un momento posterior (p. ej., mediante la inserción en el contrato, incluso de forma implícita, de la correspondiente condición); cuando una de las partes hubiera garantizado a la otra la posibilidad de cubrir determinadas expectativas que luego resultan defraudadas por circunstancias ya existentes al tiempo de contratar ${ }^{62}$; o cuando el deudor, simplemente, se compromete a ejecutar una prestación siendo (o debiendo ser) consciente ya en el momento de la celebración del contrato de que dicha prestación era de imposible realización ${ }^{63}$.

32. Es también un hecho constatado que, en aquellos supuestos en que la imposibilidad originaria de la prestación ha sido ocultada de forma dolosa o negligente por una de las partes, los tribunales tienden a admitir la posibilidad de que la otra pueda optar entre el ejercicio de las acciones derivadas de la existencia de un vicio del consentimiento (incluyendo la de anulación y la de indemnización de daños), o las derivadas del incumplimiento contractual (incluyendo la de resolución y, también en este

${ }^{60}$ En esta línea, v., p. ej., STS de 19 junio 2014 ( $R J$ 3778), en la que se aprecia incumplimiento en un caso en que se vende como libre de cargas una finca previamente gravada con un embargo que la vendedora no estaba en condiciones de levantar, ya que se estima que hubo culpa en la propia vendedora, lo que excluiría la aplicabilidad del régimen de la imposibilidad sobrevenida.

${ }^{61}$ Art. 1460: "Si al tiempo de celebrarse la venta se hubiese perdido en su totalidad la cosa objeto de la misma, quedará sin efecto el contrato. Pero si se hubiese perdido sólo en parte, el comprador podrá optar entre desistir del contrato o reclamar la parte existente, abonando su precio en proporción al total convenido".

${ }^{62} \mathrm{~V}$., en este sentido, la STS de 30 diciembre 2009 (RJ 2010/409), que rechaza la posibilidad de apreciar caso fortuito o imposibilidad liberatoria de cumplimiento (por falta de obtención de las licencias necesarias) en un supuesto en que la promotora demandada conocía, al tiempo de celebrarse el contrato, que concurrían circunstancias que, "con un alto porcentaje de probabilidad, le iban a impedir el cumplimiento de sus obligaciones contractuales, lo que ocultó a los compradores mediante una actuación calificada de dolosa que se extiende al momento de la ejecución de tales obligaciones y de su eventual imposibilidad, siendo así que el art. 1107 del CC dispone, en su párrafo segundo, que en caso de dolo responderá el deudor de todos los daños y perjuicios que conocidamente se deriven de la falta de cumplimiento de la obligación”.

${ }^{63}$ Marín López, op. cit., p. 8.704; y García Vicente, op. cit., p. 9.138, para quien "parece ser un lugar común desechar la alegación de imposibilidad originaria en aquellos casos en que de un modo u otro le resulta imputable tal imposibilidad a la parte que promete". 
caso, la de indemnización de daños), siempre que se den sus respectivos requisitos ${ }^{64}$. En ciertos casos, incluso, la jurisprudencia ha optado por aplicar soluciones propias de la imposibilidad sobrevenida no imputable (como la resolución contractual), recurriendo a la noción de "imposibilidad económica", en hipótesis que quizás podrían haberse reconducido también al ámbito del error o al de la nulidad por imposibilidad originaria ${ }^{65}$.

33. La conclusión es, por tanto, que, si bien el planteamiento literal del $\mathrm{CC}$ en este punto puede resultar ciertamente desfasado, en la práctica se han buscado soluciones alternativas más adecuadas para resolver muchos de los conflictos típicos que pueden derivarse de la imposibilidad originaria de las prestaciones, difuminándose así en buena medida la necesidad de establecer una distinción nítida entre estos supuestos y los de imposibilidad sobrevenida ${ }^{66}$. El recurso a la nulidad absoluta por falta de objeto (compatible, en su caso, con el ejercicio de las acciones fundadas en la responsabilidad precontractual de la parte conocedora de tal circunstancia) podría quedar así limitado a los supuestos de imposibilidad originaria absoluta, objetiva, definitiva y total, de tal manera que el propio contrato sea radicalmente inhábil para cumplir ninguna finalidad protegible; y también a aquellos otros en que la imposibilidad de la prestación por contravenir la ley o las buenas costumbres (art. 1271.3 CC) sea reconducible al ámbito de la ilicitud (art. 6.3), conforme a la salvedad que, como vimos, también cabe hacer respecto a los Principios.

\section{Los requisitos de la fuerza mayor en los Principios y en el Código Civil: eventos ajenos al control del deudor; imprevisibilidad; inevitabilidad; razonabilidad.}

34. Conforme al art. 7.1.7 (1) de los Principios, el deudor se exonera de las consecuencias del incumplimiento siempre que pruebe que la falta de cumplimiento se debe a un impedimento que: a) escapaba a su control; b) no podía razonablemente haber sido previsto por el deudor en el momento de la celebración del contrato; o c) no cabía razonablemente esperar que el deudor lo evitara o superara, ni que evitara o superara sus consecuencias ${ }^{67}$. Se trata de requisitos que deben concurrir de forma cumulativa, y no alternativa: no hay fuerza mayor exoneratoria cuando el impedimento se produce en la esfera de control del deudor, cuando, aun escapando a su control, cabía esperar que lo superara, o cuando, aun siendo insuperable, debía haberlo previsto al tiempo de contratar.

35. La imprevisibilidad y/o la inevitabilidad (cuya concurrencia tiende a exigirse también con carácter cumulativo ${ }^{68}$ ) son también los rasgos esenciales que caracterizan al caso fortuito en el sistema

\footnotetext{
${ }^{64}$ V. al respecto, con más detalle y cita de jurisprudencia, CARrasco, Derecho de contratos ..., cit., pp. 355 y 356.

${ }^{65}$ V. la ya citada STS de 20 abril 1994 (RJ 3216).

${ }^{66} \mathrm{~V}$., al respecto, el detenido estudio de FenOy Picón, N., "La revisión del tratamiento de la imposibilidad inicial y del error en los contratos, a través del análisis de diversos textos jurídicos". en $A D C$, t. LXX, 2017, fasc.2, pp. 473 a 785.; en sus conclusiones (p. 775), considera adecuada la tendencia normativa (reflejada en numerosos cuerpos legales y prelegislativos, entre los que cita los Principios de Unidroit, pero también, en el ámbito español, la Propuesta de Modernización del CC en materia de obligaciones y contratos de la CGC -art. 1303- y la Propuesta de CC de la APDC) a desvincular los supuestos de imposibilidad inicial de la nulidad absoluta para reconducirlos, según los casos, al régimen del error, del dolo o del incumplimiento. En un sentido similar, v. también Ribot Igualada, J., "La imposibilidad originaria del objeto contractual”, en Revista de Derecho Civil, vol. II, núm. 3 (julio-septiembre 2015), pp. 1 a 66, especialmente pp. 55 y ss.

${ }^{67}$ Nota, cit., aps. 18 y ss.

${ }^{68}$ Como señala Gil Rodríguez (op. cit., p. 302), "puede considerarse mayoritaria la opinión de que el art. 1105 no contiene dos definiciones (suceso imprevisible frente a suceso inevitable), sino un concepto único del supuesto de hecho inimputable al deudor que se integra con la doble exigencia de imprevisibilidad e inevitabilidad". Es también el planteamiento defendido por PANTALEón (con apoyo, precisamente, en la noción de caso fortuito que maneja el art. 79 de la Convención de Viena, precedente del art. 7.1.7 de los Principios; "El sistema...", cit., p. 1.060); según este autor (pp. 1.064 y ss.), la exoneración del deudor que lo sea por contrato, conforme al art. $1105 \mathrm{CC}$, supone la concurrencia de tres requisitos: a) que la falta de cumplimiento haya sido provocada por un impedimento ajeno al ámbito de control del deudor (y de sus auxiliares en el cumplimiento); b) que se trate de un suceso cuyo acaecimiento durante la vida de la relación contractual no fuera razonablemente previsible al tiempo de contratar (ya que los sucesos previsibles constituirían un riesgo implícitamente asumido por el deudor); y c) que se trate de un impedimento inevitable, en sí y en sus consecuencias, empleando la diligencia debida.
} 
español, y a ambos alude directamente el art. $1105 \mathrm{CC}$, cuando establece que, "fuera de los casos expresamente mencionados en la ley, y de los en que así lo declare la obligación, nadie responderá de aquellos sucesos que no hubieran podido preverse, o que, previstos, fueran inevitables". El precepto no exige expresamente que se trate de un suceso que escapa al control del deudor, ni tampoco alude a la "razonabilidad" como criterio que ha de servir de referencia para determinar, en cada caso concreto, la concurrencia o no de los otros requisitos; sin embargo, tales omisiones pueden ser superadas sin excesiva dificultad mediante una interpretación sistemática basada en el contexto normativo.

36. En efecto, aunque el $\mathrm{CC}$ no contiene ninguna formulación general y expresa al respecto (más allá de criterios generales, como el que se deduce del art. 1104 a propósito de la diligencia exigible al deudor, o del art. 1258, que alude a la buena fe, al uso y a la ley como instrumentos de integración del contrato), también predomina en la doctrina y la jurisprudencia españolas la idea de que, a falta de pacto específico, en el ámbito de la responsabilidad contractual solo pueden considerarse como supuestos de caso fortuito exoneratorio y/o liberatorio aquellos acontecimientos o sucesos impeditivos respecto al cumplimiento de la obligación que escapan al control del deudor o que, directamente, se producen fuera de su esfera de control ${ }^{69}$. Se entiende, en efecto, que el criterio más razonable para distribuir entre las partes el riesgo de aquellos sucesos que puedan obstaculizar el exacto cumplimiento del programa contractual ha de ser el de imputar a cada una de ellas aquellos impedimentos que puedan surgir en sus respectivos ámbitos de control ${ }^{70}$, ya que, en principio, será la parte en cuestión la que estará en mejores condiciones para prevenir el suceso y/o evitar su negativa incidencia sobre el cumplimiento, y también para probar, llegado el caso, las circunstancias del mismo ${ }^{71}$.

37. Y, por la misma razón, debe excluirse, o al menos limitarse, como regla, la responsabilidad del deudor cuando el incumplimiento se haya debido a un impedimento surgido en la esfera de control del acreedor (incluyendo los actos de las personas de las que este debe responder), con independencia de que dicho impedimento (ya se trate de falta de cooperación con el cumplimiento del deudor, incumplimiento del deber de mitigar los daños, inobservancia de las instrucciones recibidas ${ }^{72}$, etc.) fuera imprevisible o inevitable para el deudor; es decir, con independencia de que dicha intervención pueda ser

${ }^{69}$ STS de 24 octubre 2016 (RJ 4970): "Tampoco puede concebirse como caso fortuito exonerador de responsabilidad (art. 1105 CC) un suceso que cae dentro de la esfera de control de riesgo a cargo del deudor, y al que es ajeno el cliente o consumidor". STS de 5 noviembre 2012 (RJ 2013/4): "El vendedor no puede escudarse en el incumplimiento de la contrata respecto a él, porque le es imputable frente al comprador por haberla elegido, es un suceso que ocurre en el círculo de sus actividades empresariales sujetas a su control, no externo, imprevisible o inevitable (fuerza mayor)". En igual sentido, STS de 11 mayo 2016 ( $R J$ 3683), respecto a la improcedencia de considerar como supuesto de fuerza mayor, susceptible de justificar el retraso en el cumplimiento por la promotora de la obligación de entrega, las dificultades económicas de la empresa constructora, que condujeron a su declaración de concurso y obligaron a la promotora a asumir por sí misma la construcción. V. también STS de 18 julio 2013 (RJ 5532). En la doctrina, v. PANTALEÓN, “El sistema...”, cit., pp. 1.064 a 1.067; y AsúA, op. cit., p. 8.101.

${ }^{70}$ V., p. ej., STS de 3 abril 2009 (RJ 1755).

${ }^{71}$ PAntaleÓn, "El sistema...", cit., pp. 1.067-1.068. Apunta CARRASCO (Derecho de contratos ..., cit., p. 952): "Las dificultades de probar que en el interior del propio sistema de control se ha producido una contingencia imprevisible o irresistible conducen a que se acabe negando la condición de caso fortuito a dicha contingencia. (...) Lo que empieza siendo una constancia estadística provocada por el rigor de la carga de la prueba, acaba convirtiéndose en una regla de derecho por la que se imputa al deudor como riesgo propio la producción de contingencias adversas que tengan lugar en el sistema posesorio o productivo sobre el que aquél ejerce un control efectivo. El riesgo de empresa no es caso fortuito". Por esa razón, señala el mismo autor (en pp. 964-965) que las disfunciones, defectos y averías en el sistema productivo del deudor nunca constituyen casos fortuitos, sino riesgos naturales del propio sistema. Una de las manifestaciones más claras de este planteamiento en el propio CC es, probablemente, el art. 1784, que, al regular el tradicional régimen de responsabilidad del hostelero por los efectos introducidos por los clientes en su establecimiento, imputa a aquel los daños causados por sus dependientes o por extraños, "pero no los que provengan de robo a mano armada, o sean ocasionados por otro suceso de fuerza mayor". Aunque tradicionalmente se ha considerado como un régimen especial de responsabilidad, no han faltado opiniones autorizadas (como la de Jordano FraGA, $L a$ responsabilidad ..., cit., pp. 510-511; y, más recientemente, AsúA, op. cit., p. 8.101) que han explicado convincentemente el art. 1784 como una aplicación del régimen general de responsabilidad contractual en el Código Civil, y no como una excepción a ese régimen. Sobre esta norma, v. también CARRASCo (Derecho de contratos..., cit., p. 969), que le atribuye un valor presuntivo respecto a la consideración o no como caso fortuito de ciertos tipos de intervención de terceros.

${ }^{72} \mathrm{Cfr}$. art. $1783 \mathrm{CC}$, también relativo a la responsabilidad de los hosteleros por los efectos de los viajeros. 
calificada como fuerza mayor, y al margen de que la misma tenga o no un carácter doloso o negligente. Este es también el planteamiento de los Principios, que dedican a este supuesto un tratamiento específico en el art. 7.1.2, cuando establece: "(Interferencia de la otra parte) Una parte no podrá ampararse en el incumplimiento de la otra parte en la medida en que tal incumplimiento haya sido causado por acción u omisión de la primera o por cualquier otro acontecimiento por el que ésta haya asumido el riesgo".

38. La imprevisibilidad e inevitabilidad del suceso (extraño al ámbito de control de las partes) alegado como constitutivo de fuerza mayor no deben ser valoradas en términos absolutos, sino atendiendo a las circunstancias del caso concreto conforme a un criterio de razonabilidad. La noción de "razonabilidad", utilizada por los Principios a propósito de esta y de muchas otras cuestiones, no cuenta con ninguna definición en el propio instrumento, aunque, como reconoce la $N o t a^{73}$, se podría describir en términos similares a los que maneja el art. 1:302 de los Principios sobre Derecho Europeo de Contratos: "A los efectos de estos Principios la razonabilidad debe ser juzgada teniendo en cuenta lo que personas que actuasen de buena fe y en la misma situación que las partes considerarían como razonable. En particular, al valorar qué es razonable debe tenerse en cuenta la naturaleza y finalidad del contrato, las circunstancias del caso, y los usos y prácticas del sector comercial o profesional implicado”. Más allá de la mayor o menor "modernidad" o "arcaicismo" del lenguaje utilizado en uno y otro instrumento, se trata de un planteamiento en esencia coincidente con el que se deriva del CC, ya que, según ha establecido reiteradamente la jurisprudencia ${ }^{74}$, la determinación de lo que ha de considerarse como imprevisible o inevitable a efectos del art. 1105 debe hacerse teniendo en cuenta el nivel de diligencia exigible al deudor en cada caso concreto conforme a los criterios generales del art. 1104, cuando señala: "La culpa o negligencia del deudor consiste en la omisión de aquella diligencia que exija la naturaleza de la obligación y corresponda a las circunstancias de las personas, del tiempo y del lugar. Cuando la obligación no exprese la diligencia que ha de prestarse en su cumplimiento, se exigirá la que correspondería a un buen padre de familia"75. Se trata de una idea próxima a la que subyace al art. 1182, cuando supedita el efecto extintivo y liberatorio de la pérdida o destrucción de la cosa debida al hecho de que no exista culpa del deudor, lo que ha servido de base a la jurisprudencia para afirmar, con carácter general, que la ausencia de culpa del deudor es un requisito para la extinción de las obligaciones por imposibilidad sobrevenida de la prestación ${ }^{76}$.

39. Precisamente, el carácter relativo de los conceptos de previsibilidad y evitabilidad del evento impeditivo, o de la propia noción de "esfera de control", en la medida en que se vinculan a la diligencia exigible al deudor (o a la razonabilidad, según la terminología utilizada por los Principios) en función

\footnotetext{
${ }^{73}$ Nota, cit., ap. 17.

${ }^{74}$ V. p. ej., SSTS de 26 abril 2013 (RJ 3267), 17 abril 2013 (RJ 2600), 28 junio 2012 (RJ 8353), 15 julio 2010 (RJ 6049), 30 julio 2008 ( $R J 4640), 28$ abril 2008 ( $R J 2681), 20$ diciembre 2006 ( $R J 2007 / 388), 9$ junio 2005 ( $R J 4431)$ y 28 noviembre 2000 (RJ 9303). En la doctrina, v., por todos, GIL RodríGUEZ, op, cit., p. 302.

${ }^{75}$ La relación entre la imprevisibilidad y/o inevitabilidad del caso fortuito y la diligencia o culpa del deudor se refleja, p. ej., en la STS de 20 diciembre 1985 (RJ 6695), cuando señala: "La posibilidad de prever eventos dañosos o perjudiciales depende de las circunstancias de cada caso concreto, sin que, en términos generales, sea exigible una previsibilidad que exceda de la que pueda esperarse de una persona prudente respecto a los riesgos del normal discurrir de la vida, y la evitabilidad o inevitabilidad del resultado, o posibilidad o imposibilidad de impedir las consecuencias del suceso dañoso debe ponerse en relación con el grado de diligencia que deba prestarse según el tenor de la obligación y que corresponda a las circunstancias de las personas, del tiempo y del lugar”. En la misma línea, v., p. ej., SSTS de 27 junio 1986 (RJ 4401), 10 julio 2003 (RJ 4622 ), 2 enero 2006 ( $R J 129), 23$ mayo 2008 ( $R J 3171), 21$ abril 2006 ( $R J 1875)$ y las que en ellas se citan.

${ }^{76} \mathrm{~V}$. SSTS de 3 abril 2009 (RJ 1755), 30 noviembre 2006 (RJ 2007/47), 30 abril 2002 (RJ 4041), con cita de otras; y SSTS de 2 enero 1976 (RJ 22), 5 mayo 1986 (RJ 2339), 15 febrero 1994 ( $R J$ 1316), 30 mayo 1994 ( $R J 3763$ ), 22 diciembre $2000(R J 10404)$ y 21 abril 2006 ( $R J$ 1875). Apunta CARRASCO (Derecho de contratos ..., cit., p. 962), a propósito de la posible equivalencia entre caso fortuito y ausencia de culpa (o diligencia) del deudor, que tradicionalmente se ha tendido a vincular la exoneración de responsabilidad con esta última, mientras que la imposibilidad sobrevenida liberatoria exigiría el caso fortuito en sentido estricto. El propio autor observa, sin embargo, que en la práctica jurisprudencial se tiende a manejar indistintamente ambas nociones, y que, desde el punto de vista de la facilidad probatoria, resulta en general más razonable exigir la prueba -positiva- del caso fortuito que la prueba -negativa- de la ausencia de culpa del deudor. La distinción entre la noción de culpanegligencia que se maneja en materia de responsabilidad contractual (entendida como falta de la diligencia debida conforme al art. 1104) y en materia de imposibilidad sobrevenida (entendida como hecho propio o materialmente imputable al deudor; arts. 1182 y ss.) ha sido desarrollada por Badosa (op. cit., p. 258), y seguida por De Pablo Contreras (op. cit., pp. 179-180).
} 
de las circunstancias del caso concreto, determinan que, en los dos ámbitos regulatorios, no sea posible establecer, a priori, si un determinado tipo de suceso deberá ser calificado o no como fuerza mayor o caso fortuito $^{77}$. Dicho de otra manera, no es posible formular una lista de acontecimientos que, per se, deban ser considerados como constitutivos de fuerza mayor a los efectos que ahora interesan ${ }^{78}$. Es cierto que, tanto en los textos legales, como en la doctrina, en la jurisprudencia, y en los modelos contractuales habitualmente usados en determinados sectores del comercio (p. ej., en el sector de los seguros), se suele aludir a ciertos eventos como ejemplos de fuerza mayor, atendiendo a su carácter típicamente extraordinario, inhabitual, o irresistible: entre otros, se suelen mencionar acontecimientos tales como incendios, guerras, motines, disturbios, pestes o epidemias, inundaciones, explosiones, plagas, terremotos y otros desastres naturales, huelgas generales, etc. ${ }^{79}$; pero también se incluyen habitualmente los actos de la autoridad pública que impidan el cumplimiento, bien de forma directa (p. ej., requisa o expropiación, prohibición de exportar ciertos bienes o de realizar determinadas actividades) o indirecta (p. ej., cierre de fronteras, prohibición de desplazamiento al lugar donde deben prestarse los servicios), tradicionalmente englobados bajo la denominación factum principis, así como la intervención de terceros (que no sean dependientes o auxiliares del propio deudor), salvo que la misma fuera previsible o evitable, teniendo en cuenta el ámbito de control que corresponde al deudor (cfr., p. ej., el art. $1784 \mathrm{CC}$, respecto al robo a mano armada) ${ }^{80}$. Es evidente, no obstante, que incluso en el caso de sucesos como los indicados habrá que estar a las circunstancias del caso concreto para valorar, teniendo en cuenta el nivel de diligencia exigible al deudor, si los mismos no podían vincularse de ninguna manera con su esfera de control, si no debían considerarse razonablemente previsibles al tiempo de contratar ${ }^{81}$, o si, en cualquier caso, no le era posible (o exigible) evitar o superar su incidencia impeditiva sobre el cumplimiento de las obligaciones asumidas ${ }^{82}$.

${ }^{77}$ En palabras de E. Llamas Pombo (“Artículo 1105”, en Pasquau Liaño, M. (dir.), Jurisprudencia civil comentada. Código Civil, t. II, $2^{\mathrm{a}}$ ed., ed. Comares, Granada, 2009, p. 1.894), "la apreciación de la existencia del caso fortuito no se trata de una cuestión de mayor o menor probabilidad estadística de producción de un suceso, sino de que el deudor, mediante el despliegue de una conducta diligente, pudiera contar con la posible ocurrencia de tal suceso". En una línea similar, AsúA, op. cit., pp. 8.095-8.906; y Marín López, op. cit., pp. 8.704 y 8.709.

${ }^{78}$ Carrasco, Derecho de contratos..., cit., p. 949; Gil Rodríguez, op. cit., p. 303. Las SSTS de 19 diciembre 2014 (RJ 6624 y 6625) y 22 diciembre 2014 ( $R J$ 6406) niegan que la crisis inmobiliaria y financiera desencadenada a partir de 2008 pueda ser considerada, en abstracto, como un supuesto de fuerza mayor justificativo del retraso en la entrega de la obra, ya que los problemas de financiación que afectaron, concretamente, a la promotora incumplidora obedecían a circunstancias que se daban en el ámbito propio del negocio emprendido y no eran totalmente imprevisibles para aquella. También se ha rechazado la consideración como supuestos de caso fortuito, teniendo en cuenta las circunstancias concurrentes, acontecimientos tales como los conflictos laborales (STS de 14 marzo 2001, RJ 5977), los fenómenos meteorológicos adversos (SSTS de 1 diciembre 2000, $R J$ 9321, 15 marzo 2001, RJ 5979, y 12 septiembre 2002, RJ 8555), o los atentados terroristas (SSTS de 11 octubre 2005, RJ 8769 , y 2 febrero 2006, $R J 2694$, que descartan la imprevisibilidad de los ataques terroristas que provocaron graves lesiones, $\mathrm{e}$ incluso la muerte, a varios turistas, ya que previamente se habían producido otros ataques en el mismo país y en la misma zona, y las entidades organizadoras del viaje lo sabían).

${ }^{79}$ Un buen ejemplo lo encontramos en el vetusto art. $1575 \mathrm{CC}$, que cita como ejemplos de caso fortuito extraordinario (susceptible de fundamentar la rebaja de la renta, a instancias del arrendatario de finca rústica, cuando supongan la pérdida de más de la mitad de los frutos) "el incendio, guerra, peste, inundación insólita, langosta, terremoto u otro igualmente desacostumbrado, y que los contratantes no hayan podido racionalmente prever".

${ }^{80}$ V., p. ej., STS de 21 febrero 2011 ( $R J$ 2364), que descarta la calificación como caso fortuito de la intrusión de terceros en el sistema de seguridad establecido, por tratarse de una circunstancia previsible. En cambio, sí se consideró exonerado al deudor en un caso de atraco a mano armada en la STS de 15 marzo 1990 (RJ 1696).

${ }^{81}$ Como advierte J.C. Rivera ("Los contratos frente a la pandemia”, en Arcos ValCÁrcel, S.S. y otros, Covid-19 y Derecho. Contratos, ed. Thomson Reuters La Ley, Buenos Aires, 2020, p. 7), en términos aplicables también a la fuerza mayor, "la teoría de la imprevisión considera como acontecimiento extraordinario el que no es normal que se verifique, sin que la imprevisibilidad se entienda con sentido absoluto, ya que conforme a la experiencia cualquier acontecer, aunque sea inesperado, puede ser conocido y eventualmente pensado".

${ }^{82}$ La STS de 30 abril 2002 ( $R J$ 4041) recuerda que la jurisprudencia exige, para apreciar imposibilidad liberatoria, que el deudor haya observado la debida diligencia haciendo lo posible para vencer la imposibilidad (STS de 14 febrero 1994, $R J$ 1467), o agotando las posibilidades de cumplimiento (STS de 2 octubre 1970, $R J$ 4038); mientras que la STS de 3 abril 2009 ( $R J$ 1755), citando otras anteriores, recuerda que no hay imposibilidad cuando se puede cumplir con un esfuerzo de la voluntad del deudor. La propia sentencia advierte, no obstante, que "el esfuerzo del deudor para cumplir, cuando la prestación no ha sido correctamente ejecutada en el tiempo convenido, no le exonera por si mismo, ni menos equivale al cumplimiento. Se requiere el "caso fortuito" (artículo 1105 CC) que alguna jurisprudencia hace equivaler a la ausencia de culpa, pero siempre que la posibilidad de previsión se mida de acuerdo con los criterios de la diligencia exigible o prestable”. 
40. Dispone el art. 7.1.7 (2) de los Principios que, "cuando el impedimento es solo temporal, la exoneración produce efectos durante un periodo razonable, teniendo en cuenta los efectos del impedimento sobre la ejecución del contrato". Aunque en el CC no existe una previsión paralela, en la doctrina y la jurisprudencia españolas se entiende habitualmente que, cuando la imposibilidad sobrevenida de la prestación por causa no imputable al deudor tenga un carácter meramente temporal o transitorio, no se extinguirá la obligación, sino que solo se suspenderá su exigibilidad hasta que aquella desaparezca, siempre que ello siga respondiendo al interés del acreedor, aunque este deberá soportar las consecuencias del retraso ${ }^{83}$. La obligación se extinguirá, no obstante, cuando el cumplimiento tardío no pueda satisfacer el interés del acreedor (p. ej., en los supuestos de término esencial absoluto ${ }^{84}$ ), o cuando, siendo la prestación actualmente imposible, no pueda imponerse al acreedor, o al propio deudor, una espera indefinida, aun cuando se prevea la eventualidad de que llegue a ser posible ${ }^{85}$.

41. Al regular la suspensión consiguiente a los impedimentos meramente temporales, los Principios introducen un elemento adicional respecto al régimen del CC que resulta, sin duda, acertado: se trata de la previsión según la cual la exoneración de responsabilidad para el deudor se producirá "durante un periodo razonable, teniendo en cuenta los efectos del impedimento sobre la ejecución del contrato"; lo que significa que el tiempo extra con el que podrá contar el deudor para cumplir cuando se haya visto afectado por un impedimento temporal podrá tener una duración mayor o menor que la del propio impedimento, "porque lo que importa es determinar el impacto del impedimento en el cumplimiento del contrato" $"$.

42. Conforme al art. 7.1.7 (1) de los Principios, corresponde al deudor la carga de la prueba sobre la concurrencia de un supuesto de fuerza mayor impeditivo del cumplimiento y de los requisitos exigidos para atribuirle eficacia exoneratoria ${ }^{87}$. A la misma solución cabe llegar en el sistema del CC español: de acuerdo con las reglas generales sobre distribución de la carga de la prueba (cfr. art. 217 LEC, en especial su apartado 3), incumbe al demandado la carga de probar los hechos que, conforme a las normas aplicables, "impidan, extingan o enerven la eficacia jurídica de los hechos a que se refiere el apartado anterior"; lo que significa que, una vez probada por el acreedor demandante la existencia de la obligación reclamada, corresponderá al deudor demandado probar la concurrencia de los presupuestos de hecho que justifican la exoneración de responsabilidad o, en su caso, la extinción liberatoria de la obligación por imposibilidad sobrevenida no imputable: en definitiva, la prueba del caso fortuito o de la fuerza mayor ${ }^{88}$.

${ }^{83}$ STS de 13 junio 1944 ( $R J$ 893), en la que se plantea el supuesto de un vendedor de aceite que se vio temporalmente imposibilitado de cumplir su obligación de entrega como consecuencia de la guerra civil española: "La fuerza mayor dimanante de la guerra, operando en obligaciones genéricas por ella afectadas, no produce, en principio, efectos extintivos por imposibilidad absoluta y permanente de cumplimiento, en atención a que el género no parece, pero produce, corrientemente, imposibilidad pasajera, con efectos meramente suspensivos, en aquellos casos en que al cesar la actuación de la fuerza mayor, revive la obligación contraida, si llena entonces la finalidad buscada por los interesados al tiempo de la celebración del contrato". V. también SSTS de 25 marzo 1947 (RJ 542), 3 marzo 1948 (RJ 286), 9 enero 1951 (RJ 581 ), 24 octubre 1953 (RJ 3122), 10 diciembre 1963 (RJ 5220), 13 marzo 1987 (RJ 1480), 30 abril 2002 (RJ 4041) y 21 abril 2006 ( $R J 1875)$. Recuérdese también la jurisprudencia según la cual solo el retraso culpable implica mora e impone por tanto, al deudor, la obligación de indemnizar los daños (v. supra, n. 46).

${ }^{84}$ STS de 24 septiembre 1953 (RJ 2277).

${ }^{85}$ SSTS de 5 noviembre 1982 (RJ 6528) y 23 febrero 1994 (RJ 1995/683). En esta última se considera extinguida -y no meramente suspendida- por imposibilidad sobrevenida no imputable la obligación de construir y transmitir una nave industrial, por no haber obtenido la vendedora las licencias necesarias, con el siguiente razonamiento: "Las circunstancias concurrentes quizá revelen la eventualidad de una futura posibilidad de que la vendedora diese cumplimiento a sus obligaciones contractuales, pero ello no elimina la certeza de la imposibilidad existente en el momento en que se instó la resolución, imposibilidad que, como se ha dicho, no es imputable a negligencia de aquélla, a quien no es procedente imponer un retraso indefinido en el cumplimiento de su prestación sin certeza alguna sobre que pudiera llevarse a efecto alguna vez, ya que, de lo contrario, quebraría el equilibrio contractual con evidente perjuicio para la vendedora”.

${ }^{86}$ Comentario, cit., p. 241.

${ }^{87}$ Nota, cit., ap. 24.

${ }^{88}$ En este sentido, STS de 31 mayo 1985 (RJ 2835). 
43. El mismo principio puede deducirse del art. $1183 \mathrm{CC}$, que, refiriéndose concretamente a las obligaciones de dar cosa determinada, establece que "la culpa del deudor se presume, salvo prueba en contrario, cuando la cosa se perdió estando en su poder". Aunque en algún caso se ha afirmado ${ }^{89}$ que el art. 1183, en cuanto se basa en la posesión de la cosa por el deudor ${ }^{90}$, es una norma específica que excluye la aplicación de las reglas generales sobre distribución de la carga de la prueba, lo cierto es que la misma es coherente con la norma general de atribución al deudor de la carga de la prueba sobre los hechos extintivos o impeditivos de su obligación ${ }^{91}$, y también, en la mayor parte de los casos, con el criterio de la mayor disponibilidad o facilidad probatoria que se deriva del art. 217.7 LEC; regla general que, por tanto, puede considerarse también aplicable a las obligaciones de hacer que tengan por objeto un resultado, cuando este no se obtenga ${ }^{92}$, y a las obligaciones de no hacer ${ }^{93}$. Respecto a las obligaciones de hacer que tienen por objeto la prestación de una actividad diligente (obligaciones de medios), se ha entendido con frecuencia, por el contrario, que se invierte la carga de la prueba, de tal manera que el deudor no responde a menos que el acreedor pruebe que aquel no desplegó la diligencia exigible ${ }^{94}$. Por nuestra parte, coincidimos con la idea de que la diferencia entre ambos tipos de obligaciones no debe situarse en las reglas de imputación de responsabilidad o exoneración ni en las relativas a la atribución de la carga de la prueba sobre el caso fortuito, sino en el distinto contenido de la prestación y, en consecuencia, en la determinación de cuándo hay cumplimiento y cuándo se produce el hecho material del incumplimiento, como presupuesto para la -posible- imputación de responsabilidad ${ }^{95}$. Planteamiento este que, por cierto, es más próximo al que acogen los Principios, cuyos arts. 5.1.4 y 5.1.5 se hacen eco de la distinción entre obligaciones de medios y de resultado, pero no la vinculan con el tema de la atribución de la carga de la prueba, sino con la determinación del contenido de las obligaciones contractualmente asumidas ${ }^{96}$.

44. La eficacia exoneratoria de la fuerza mayor en los Principios no conoce más excepciones que las que se deriven de los acuerdos alcanzados por los contratantes respecto a la asunción por una u otra parte del riesgo correspondiente. En este punto, la regulación del CC español (cfr. el propio art. 1105 ) resulta más circunstanciada, ya que, al margen de los casos en que la parte deudora haya asumido por pacto el riesgo de tales eventos (supuesto en el que se suele hablar de "obligación de garantía"), la ley también atribuye dicho riesgo al deudor en diferentes supuestos, normalmente vinculados con la observancia por su parte de un comportamiento ilícito anterior a la producción del evento que impide el incumplimiento ${ }^{97}$. Al margen de otros casos de menor relevancia ${ }^{98}$, el deudor responderá, aunque la imposibilidad de cumplimiento no le sea imputable, cuando se hallara previamente constituido en situación

${ }^{89}$ STS de 12 diciembre 1988 (RJ9433).

${ }^{90}$ STS de 2 octubre 1995 (RJ 6977).

${ }^{91}$ En este sentido, SSTS de 24 mayo 1974 ( $\left.R J 2102\right), 28$ enero 1998 ( $\left.R J 357\right), 15$ marzo 2002 ( $R J 2843$ ). Sobre la presunción de culpa en los casos de incumplimiento, v. STS de 17 febrero 2005 (RJ 1679).

${ }^{92}$ SSTS de 22 abril 1997 (RJ 3249) y 28 junio 1999 (RJ 4894).

${ }^{93}$ Gil Rodríguez, op. cit., p. 305; De Pablo, op. cit., p. 179, con cita de la STS de 28 enero 1998 (RJ 357). Este último autor opina, no obstante (en p. 190) que lo que se presume en el art. 1183 es la "culpa-hecho propio", que excluye la extinción liberatoria de la obligación, mientras que la "culpa-negligencia" del art. 1104, relevante a efectos indemnizatorios, habría de ser probada por el acreedor; aunque reconoce que la jurisprudencia tradicional ha atribuido un alcance más amplio a la presunción de culpa derivada del art. 1183.

${ }^{94}$ SSTS de 16 diciembre 1997 (RJ 8690), 19 febrero 1998 (RJ 634) y 13 abril 1999 (RJ 3583), para supuestos de responsabilidad médica; y SSTS de 23 mayo 2001 ( $R J 3372), 30$ diciembre 2002 ( $R J$ 2003/333), 30 marzo 2006 ( $R J 2029$ ), y 28 junio 2012 ( $R J$ 10403), para supuestos de responsabilidad del abogado. Para un contrato de servicios de vigilancia y seguridad, STS de 21 febrero 2011 (RJ 2364).

${ }^{95} \mathrm{~V}$. al respecto las reflexiones de Jordano Fraga, F., "Obligaciones de medios y de resultado (a propósito de alguna jurisprudencia reciente)", en $A D C$, 1991, t. XLIV, pp. 5 a 96, especialmente p. 96, en sede de conclusiones.

${ }^{96}$ En esta línea, para el Derecho español, señala la STS de 26 abril 2013 (RJ 3267) que la obligación de resultado se diferencia de la de medios porque integra en el contenido de la prestación debida el resultado buscado por las partes; lo que no excluye que también en las obligaciones de resultado quepa la exoneración del deudor por caso fortuito o fuerza mayor conforme a los arts. 1105,1182 y 1184 .

${ }^{97}$ Badosa, “Artículo 1105”, en Comentario..., cit., p. 44.

${ }^{98}$ Así, p. ej., se atribuye el riesgo del caso fortuito al deudor cuando se hubiera comprometido a entregar una misma cosa a dos o más personas (art. 1096.3), y cuando la obligación (de restituir) procediere de delito o falta, salvo que el acreedor hubiera incurrido a su vez en mora creditoris (art. 1185), o la pérdida se deba a culpa del propio acreedor. 
de mora (arts. 1096.3 y 1182) 99 ; si bien se entiende que la atribución de dicho riesgo cesará desde el momento en que el acreedor incurra en mora creditoris ${ }^{100}$, o en mora debitoris (en el caso de obligaciones sinalagmáticas), y también, según una opinión, cuando el deudor pruebe que la pérdida fortuita se habría producido igualmente aunque la cosa se hallase en poder del acreedor ${ }^{101}$.

\section{Los requisitos de la fuerza mayor exoneradora y/o liberatoria en el contexto de la crisis genera- da por el coronavirus}

\section{A) Las circunstancias del caso concreto}

45. A la vista de las consideraciones generales expuestas en el apartado anterior, resulta evidente que la posibilidad de aplicar el régimen de la fuerza mayor o del caso fortuito a las relaciones contractuales directa o indirectamente afectadas por la crisis del coronavirus habrá de determinarse, no a partir de valoraciones de carácter general, sino a la vista de las circunstancias concurrentes en cada caso concreto. No cabe duda de que las características que presenta la pandemia del coronavirus (su extraordinaria capacidad de contagio, su alto nivel de letalidad, su rápida propagación a escala mundial..., en absoluto comparables con las epidemias conocidas, al menos en el último siglo) y, en consecuencia, las medidas adoptadas para combatirla (el elevado -e inusitado- nivel de restricción que suponen para la movilidad de las personas y para el desarrollo de múltiples actividades económicas y sociales, incluso a nivel internacional, la afectación general de la población...) pueden implicar, en muchos casos, una restricción especialmente intensa de la capacidad de los deudores para prever, evitar y superar los impedimentos derivados de ella y dar, por tanto, exacto cumplimiento a sus obligaciones ${ }^{102}$. Hay que insistir no obstante en que, por más que, en abstracto, la pandemia del coronavirus pueda considerarse como un acontecimiento imprevisible e inevitable, lo relevante, desde el punto de vista contractual, es valorar si se trata de un suceso imprevisible e inevitable para las partes en cada caso concreto ${ }^{103}$.

46. En el terreno probatorio, habrá que insistir igualmente en que ni la notoriedad de la pandemia, ni la publicidad de las medidas adoptadas, eximen al deudor que pretenda alegar la fuerza mayor de la carga de probar, en atención a las circunstancias del caso concreto, que tales sucesos escapaban por completo a su control, que eran imprevisibles para él, y que no le era posible (o exigible) evitar o superar sus consecuencias impeditivas sobre el cumplimiento de las obligaciones asumidas. Entre las circunstancias relevantes a estos efectos, habrá que considerar, especialmente, cuál sea el concreto impedimento alegado en cada caso (la propia enfermedad del deudor o de otros, las medidas generales o individuales de confinamiento o cuarentena impuestas, las medidas restrictivas de la actividad económica y social, las dificultades económicas derivadas de unas y otras... $)^{104}$, las circunstancias de tiempo,

${ }^{99}$ SSTS de 2 octubre 1984 (RJ 4752), 15 diciembre 1987 (RJ 9434), 23 febrero 1994 (RJ 1995/683), 30 noviembre 2006 (2007/241) y STS de 3 abril 2009 (RJ 1755). A este supuesto podrían reconducirse determinados casos de atribución al deudor del riesgo del caso fortuito, en los que cabría entender que el deudor se halla automáticamente en situación de mora: v., p. ej., art. 1896 (cobro de lo indebido con mala fe); 457 (retraso de mala fe en la devolución de la cosa ajena poseída); y 1744 (retraso en la devolución o uso distinto al pactado en el comodato).

${ }^{100}$ Marín López, op. cit., p. 8.710; De Pablo, op. cit., p. 182.

${ }^{101}$ En este sentido, por aplicación analógica de lo previsto en el art. 1896.2 para el que recibe un pago indebido con mala fe, v. MARÍN López (op. cit., p. 8.710), con cita de otros autores; advirtiendo, no obstante, que la cuestión ha sido discutida.

${ }^{102}$ Seguramente, una situación de pandemia como la que vivimos podría considerarse imprevisible, incluso, para aquellos contratantes que, consciente o inconscientemente, la habían previsto como posible supuesto de fuerza mayor en sus contratos, quizá como resultado de la utilización de formularios más o menos estereotipados. Lo cual no excluye que, en tales casos, haya que estar a lo pactado, tal como recuerda Carrasco Perera en "Permítame que le cuente la verdad sobre COVID-19 y fuerza mayor", en Publicaciones jurídicas, Centro de Estudios de Consumo, abril 2020, p. 2: "Una cláusula de 'todos los riesgos' es, efectivamente, una cláusula de todos los riesgos".

${ }^{103}$ Gregoraci, op. cit., pp. 459-460.

${ }^{104}$ Aunque la Nota (op. cit., ap. 12), en aras de evitar una excesiva complejidad en el análisis, considera oportuno centrarse sobre la enfermedad en sí misma y sobre las medidas adoptadas para contenerla como posibles circunstancias impeditivas del cumplimiento de las obligaciones, a nuestro juicio no puede obviarse la trascendencia que, a estos efectos, habrá de asumir 
lugar y sector económico implicado, el tipo de obligaciones asumidas (personalísimas o no personalísimas, de dar cosas específicas o genéricas, de hacer o no hacer, de dinero, etc.), la duración prevista de los contratos (que se trate de relaciones instantáneas, de cumplimiento diferido a corto plazo, de tracto continuado o sucesivo a medio o largo plazo...), las circunstancias personales de los sujetos implicados (su condición de empresarios, profesionales o consumidores), y, por supuesto, los pactos expresos o tácitos alcanzados por las partes.

\section{B) La esfera de control de las partes.}

47. En una primera aproximación, habrá que convenir en que, en principio, tanto la enfermedad en sí misma considerada como las medidas adoptadas por las autoridades para combatirla deben considerarse como sucesos ajenos, por su propia naturaleza, a la esfera de control de ambas partes, ya que estas difícilmente podrían haber influido en el origen de ninguno de ellos ${ }^{105}$. Cabría matizar, no obstante, que, en la actual situación, lo que sí entra dentro de la esfera de control de cada una de las partes -ya se trate del deudor o del acreedor- es la adopción, dentro de sus respectivos ámbitos, de las medidas de control y precaución necesarias para hacer posible el cumplimiento de un determinado contrato, tanto desde el punto de vista estrictamente sanitario como desde el punto de vista del cumplimiento de las exigencias de seguridad impuestas por las autoridades ${ }^{106}$; y así, p. ej., ni la enfermedad ni las medidas de contención podrán servir de base para alegar el caso fortuito o la fuerza mayor cuando el incumplimiento del contrato tenga su causa inmediata en la no adopción por el deudor de las medidas o precauciones impuestas en cada caso por las autoridades (p. ej., sobre control de accesos, aforo, distancias de seguridad, medidas de higiene, etc.), sin perjuicio de que, en su caso, la necesidad de observar tales medidas pueda dar lugar a una modificación -justificada- de la prestación compatible, todavía, con el interés del acreedor (p. ej., alterando el tiempo o modalidad de prestación del servicio comprometido). Del mismo modo, no habrá lugar a exigir responsabilidad al deudor cuando su incumplimiento se deba a la inobservancia por parte del acreedor o de las personas que de él dependan de las medidas de seguridad o precaución exigibles para hacer posible el cumplimiento del contrato (p. ej., la observancia de los controles impuestos para acceder al local o al medio de transporte de que se trate), con independencia de que tal comportamiento pueda o no ser calificado en sí mismo como un supuesto de fuerza mayor por su carácter imprevisible y/o inevitable.

48. Como regla general no podrán considerarse como contingencias ajenas a la esfera de control del deudor -y, por tanto, no podrán calificarse como supuestos de fuerza mayor exoneratoria- las dificultades de cumplimiento relacionadas con su particular situación económica (problemas de liquidez, insolvencia, etc. $)^{107}$. Eventualmente, sí cabría atribuir relevancia a los impedimentos para el cumplimiento

la crisis económica derivada de los factores apuntados. El precedente, todavía próximo, de la crisis financiera de 2008, es un claro ejemplo de que, precisamente, las dificultades económicas experimentadas por los ciudadanos, por las empresas, e incluso por las Administraciones Públicas, como consecuencia de una crisis global han sido, durante los últimos años, el detonante, en España, de un ingente número de pleitos relacionados, singularmente, con la aplicación de la doctrina jurisprudencial de la cláusula rebus sic stantibus. V. infra, III.3.

${ }^{105}$ Advierte la Nota (ap. 18) que la exigencia de control se refiere tanto al impedimento en cuanto tal (p. ej., la pandemia o el confinamiento) como a su aptitud para afectar al cumplimiento en general, pero no se refiere a la situación subjetiva del deudor; y así, p. ej. -se señala-, probablemente no cabría alegar la excepción de fuerza mayor cuando el deudor persona física ha incumplido un contrato intuitu personae por haber contraído la enfermedad de forma voluntaria o imprudente; pero no porque se pudiera decir que su salud estaba "bajo su control", sino más bien porque en tal caso se podría apreciar una actuación contraria a la buena fe y/o una incapacidad del deudor para superar las circunstancias.

${ }^{106}$ Hasta el punto de que la adopción de tales medidas podrá considerarse como un deber accesorio integrador de las respectivas obligaciones conforme al art. $1258 \mathrm{CC}$.

${ }^{107}$ SSTS de 19 diciembre 2014 ( $R J 6624$ y 6625) y 22 diciembre 2014 (RJ 6406). Excepcionalmente, la incidencia de este tipo de circunstancias sobre el cumplimiento de los contratos sí podrá ser tenida en cuenta por los tribunales por aplicación de normas específicas, como el art. 11 de la Ley 28/1998, de 13 de julio, de Venta a Plazos de Bienes Muebles, que reconoce a los Jueces y Tribunales la posibilidad de modificar el contenido de los contratos "con carácter excepcional y por justas causas apreciadas discrecionalmente, tales como desgracias familiares, paro, accidentes de trabajo, larga enfermedad u otros infortunios". Pero recuérdese que también el art. 1124.3 CC, en términos más generales, permite que, ante el ejercicio de la acción 
que tengan su origen en circunstancias de alcance general relacionadas con la crisis económica derivada de la pandemia y de las medidas adoptadas para controlarla (p. ej., problemas generalizados relacionados con la restricción de las fuentes de financiación, el cierre de empresas, la suspensión o extinción de relaciones laborales, las dificultades para mantener las cadenas de distribución, la caída del consumo y la inversión, con la consiguiente restricción de la demanda, el encarecimiento de ciertos bienes y servicios, etc.). Aunque no cabe descartar que en ciertos casos tales circunstancias puedan justificar la aplicación del régimen de la fuerza mayor como fundamento de la exoneración o incluso de la liberación definitiva o temporal del deudor, con frecuencia este tipo de situaciones podrán reconducirse más bien a otros ámbitos, como el de la excesiva onerosidad sobrevenida, la desaparición de la base del negocio, u otros ${ }^{108}$.

\section{C) La previsibilidad}

49. Son constitutivos de fuerza mayor exoneratoria aquellos sucesos impeditivos ajenos a la esfera de control del deudor que fueran razonablemente imprevisibles para él al tiempo de contratar, teniendo en cuenta el nivel de diligencia que le era exigible a tenor de las circunstancias; en cambio, aquellos que fueran razonablemente previsibles para el deudor deben considerarse, en principio, como riesgos implícitamente asumidos por él. A propósito de la previsibilidad -o no- de los impedimentos relacionados con la pandemia, la Nota centra su análisis en las coordenadas de tiempo y lugar ${ }^{109}$, considerando, por un lado, la fecha del contrato y el lugar de establecimiento de las partes en cada caso concreto, y, por otro, las diferentes fases de evolución de la pandemia en los distintos países y regiones; respecto a cada país en concreto, lo relevante sería, en este sentido, determinar el momento en que la situación alcanzó un cierto nivel de gravedad y atrajo suficientemente la atención del público de ese país, así como el tipo de medidas de control que se adoptaron y su calendario ${ }^{110}$. A nuestro juicio, a la hora de valorar la previsibilidad puede ser conveniente tener en cuenta ciertos factores adicionales, como el concreto sector económico afectado, la posible profesionalidad de las partes, o el hecho de que se trate de contratos de ejecución instantánea o llamados a producir sus efectos a corto, medio o largo plazo, ya que es evidente que estos últimos están expuestos en mayor medida a la eventualidad de verse afectados por sucesos inicialmente imprevisibles (o poco previsibles).

50. En lo que se refiere concretamente al factor temporal, se señalaba en la Nota ${ }^{111}$ la necesidad de tener en cuenta si el contrato en cuestión se había celebrado (1) antes de que se informara sobre la aparición de los primeros casos de la enfermedad en China (31 de diciembre de 2019); (2) después de ese momento, pero antes de que la OMS declarara la situación de pandemia (11 de marzo de 2020); (3) durante el estado de emergencia en el país relevante; y (4) después de que el estado de emergencia terminara. Transcurridos varios meses desde la elaboración y publicación de la Nota, parece claro que los hitos temporales señalados habrán de ser revisados o actualizados a tenor de la posterior evolución de las circunstancias en cada zona geográfica.

51. En el caso de España, ya hemos señalado que el impacto inicial de la pandemia se produjo en un momento relativamente temprano, y su evolución fue muy rápida, pasando en pocas semanas de la aparición de los primeros casos aislados a una fase de contagio comunitario que obligó a las autoridades a adoptar medidas muy estrictas, todo ello con el conocimiento general de la sociedad española: como apuntábamos, la declaración del estado de alarma, que llevó consigo el confinamiento domiciliario obligatorio de la población en general, tuvo lugar el 14 de marzo, solo tres días después de que la OMS

\footnotetext{
resolutoria por incumplimiento, el tribunal considere que se dan causas justificadas para señalar al deudor un plazo adicional de cumplimiento.

${ }^{108}$ Nota, cit., ap. 15.

${ }^{109}$ Nota, cit., ap. 11.

${ }^{110}$ Nota, cit., aps. 19 y ss.

${ }^{111}$ Nota, cit., ap. 11.
} 
declarase formalmente que el COVID-19 se había convertido en una pandemia. Habida cuenta de que en las fechas inmediatamente anteriores a la declaración de alarma, si bien la existencia del virus era de dominio público y había una preocupación generalizada entre la población española, también existía una gran incertidumbre sobre la gravedad, duración, y posibles consecuencias sociales y económicas de su expansión, parece razonable fijar en torno a las fechas señaladas (del 11 al 14 de marzo) el paso de una situación general de imprevisibilidad a otra de previsibilidad en cuanto a la consideración de la enfermedad y de las consiguientes medidas como posibles impedimentos para el cumplimiento de las obligaciones asumidas en la mayor parte de los sectores económicos. La diferencia entre las diversas zonas geográficas dentro del territorio español, en esta fase, puede considerarse, en general, poco relevante, ya que los contagios se extendieron rápidamente por todo el territorio, con un grado elevado de uniformidad; y las medidas adoptadas para contenerlo, inicialmente, alcanzaron igualmente a todo el país.

52. Más dificultades plantea la valoración del factor de previsibilidad si se considera, en particular, la fase en que comenzó la llamada "desescalada" que, en principio, había de llevar a las distintas zonas de España desde una situación de confinamiento a otra de "nueva normalidad" coincidiendo, aproximadamente, con el inicio de la temporada estival. Parece claro que, al menos en un primer momento, sí hubo un periodo en el que existieron expectativas razonables de que pudiera recuperarse, en cierta medida, la actividad económica en la mayor parte de los sectores. Y no resulta descabellado pensar que, en ese periodo (que podría situarse, aproximadamente, entre los primeros días de junio y mediados de julio), pudieron celebrarse numerosos contratos (p. ej., relacionados con el turismo) respecto de los cuales la superveniencia de impedimentos relacionados con la crisis sanitaria pudiera considerarse como algo -relativamente- imprevisible; al menos a corto y medio plazo, ya que sí se puede dar por cierto que, en todo ese periodo, la población española en general era consciente de que, con la llegada del otoño, lo más probable es que se produjeran rebrotes, e incluso una segunda oleada de la enfermedad. Lo que quizá no era previsible en ese momento es que los rebrotes empezaran a proliferar ya durante julio y agosto, multiplicando así los impedimentos para el cumplimiento de contratos celebrados durante el periodo de desescalada -y también para contratos celebrados antes del inicio de la crisis, pero respecto de los cuales las partes habían conseguido mantener su vigencia, quizá en previsión de que las circunstancias mejoraran con la llegada del verano-. A partir del mes de agosto, se puede afirmar con bastante rotundidad que la presencia de la enfermedad y de las medidas de contención era una realidad con la que, en general, se sabía que sería necesario convivir en los meses siguientes y con carácter indefinido, al menos hasta que la dispensación masiva de vacunas o la aparición de un tratamiento efectivo contra la enfermedad permitiera vislumbrar la definitiva superación de la crisis sanitaria.

53. Desde entonces, y hasta el momento presente, la crisis ha ido experimentando altibajos en cuanto a su nivel de gravedad, instalándonos en una situación "estable" de incertidumbre, de duración indefinida. Las medidas que se están adoptando en la fase actual tienen un marcado carácter territorial, ya que, en respuesta a las exigencias que van surgiendo en cada momento, las restricciones a la movilidad y a la actividad social y económica se proyectan sobre espacios diversos (regiones, provincias, comarcas, poblaciones, o incluso barrios). Desde el punto de vista temporal, las curvas de la enfermedad no están siguiendo un patrón definido, de manera que territorios que habían conseguido mantener un nivel relativamente bajo de contagios, o controlar los primeros picos de la enfermedad, vuelven algún tiempo después a experimentar crecimientos importantes, lo que a su vez obliga a reactivar las restricciones con contenidos y niveles de intensidad igualmente cambiantes. A ello hay que añadir que las medidas adoptadas -no solo en España, sino también en otros países de nuestro entorno, especialmente aquellos de los que procede la mayor parte del turismo- están incidiendo de manera desigual en los diferentes sectores económicos: si en la primera oleada las restricciones afectaron de forma generalizada prácticamente a todos los ámbitos de la actividad económica, dejando a salvo únicamente determinados sectores esenciales (sanitario, alimentario, información y comunicación, etc.), en el momento actual resulta evidente que las medidas adoptadas están incidiendo de forma especialmente grave sobre determinados sectores concretos (turismo, transportes, hostelería, ocio nocturno, actividad cultural, comercio de proximidad, entre otros); y, si bien la crisis está afectando en mayor o menor medida a todos los ámbi- 
tos económicos, también es cierto que algunos sectores están experimentando importantes incrementos de actividad (p. ej., la industria de contenidos digitales, la distribución de productos a domicilio, o las empresas dedicadas a la rehabilitación y reforma de viviendas). Y todo ello, con la perspectiva real de que las circunstancias de cada momento y lugar puedan cambiar sensiblemente en un breve espacio de tiempo en función de la evolución de las cifras de la enfermedad.

54. Así las cosas, el análisis prospectivo que realiza la Nota ${ }^{112}$ acerca de la valoración del factor "previsibilidad" de cara a la futura superación de la pandemia y el correlativo levantamiento de las medidas resulta, en el momento actual, imposible de concretar. Parece claro que, en tanto no se alcance un nivel elevado de inmunidad en la población mediante la aplicación masiva de vacunas (un proceso que, en el mejor de los casos, llevará meses), o se encuentre un tratamiento eficaz contra la enfermedad, tanto los rebrotes localizados como las sucesivas oleadas generales seguirán produciéndose, prácticamente, sin solución de continuidad. Hasta ese momento, como señala la Nota, cabe pensar que no habrá un momento definido de final de la crisis sanitaria; y tampoco es posible prever, en el momento actual, si las medidas que habrán de adoptarse hasta entonces tendrán un carácter local, regional o nacional, y cuál será la intensidad y la duración de las mismas.

\section{D) Las cláusulas contractuales ad hoc}

55. En estas circunstancias, es evidente que las partes de cualquier contrato que, en España o en cualquier otro país, se celebre en el futuro inmediato y durante los próximos meses -salvo que se trate de contratos de tracto único o llamados a cumplirse en un espacio de tiempo muy breve-, o bien de aquellos anteriores que estén sujetos a renegociación, habrán de tener en cuenta la posible incidencia de la crisis del coronavirus y sus derivaciones (medidas gubernamentales, crisis económica), ya que, llegados a este punto, tales sucesos difícilmente podrán considerarse como imprevisibles y, por tanto, susceptibles de fundamentar la aplicación del régimen de la fuerza mayor (o de otros, como el de la excesiva onerosidad sobrevenida) ${ }^{113}$. Lo aconsejable, por tanto, será que en la redacción de los contratos (y siempre dentro de los límites reconocidos a la autonomía de la voluntad en cada ámbito) se incluyan cláusulas específicas orientadas a regular las consecuencias que sobre la relación contractual habrá de tener la eventual superveniencia de circunstancias vinculadas a la pandemia y que puedan dificultar o impedir el cumplimiento normal de las obligaciones contractuales.

56. Las propuestas que plantea al respecto la $\mathrm{Nota}^{114}$ pueden constituir una guía muy útil sobre las cuestiones que podrían ser abordadas en dichas cláusulas (que, en puridad, ya no sería correcto denominar "cláusulas de fuerza mayor", sino, en todo caso, "cláusulas COVID-19"). Entre tales cuestiones cabría mencionar, p. ej., las relacionadas con la obligación de notificar a la otra parte sin demora indebida cualquier circunstancia relacionada con la pandemia que pueda ser relevante para el desarrollo de la relación contractual (incluyendo la comunicación de la existencia de un impedimento para el cumplimiento de las obligaciones contractuales, el alcance del mismo, y, en el caso de impedimentos de carácter temporal, el momento en que el deudor esté en condiciones de reiniciar el cumplimiento del contrato); el tipo de documentación que habrá de aportarse en cada caso para justificar la concurrencia de tales circunstancias; las consecuencias que habrá de tener para la relación el hecho de que se aprueben ciertos tipos de medidas de contención (p. ej., en función de su alcance temporal o territorial); la posible asunción por una u otra parte del riesgo de que se den ciertos tipos de circunstancias; las medidas que ha-

\footnotetext{
${ }^{112}$ Nota, cit., ap. 23.

${ }^{113}$ La consideración de las posibles situaciones de pandemia como eventos de fuerza mayor en la negociación y redacción de los contratos se prolongará, previsiblemente, más allá del futuro inmediato; como señala GómEz LigÜERRE, (op. cit., p. 1), "la situación actual quedará en nuestra memoria colectiva -social, económica y jurídica- y, a partir de ahora, ya no habrá contratos de cierta complejidad que prescindan de una cláusula que prevea una solución contractual para casos como el presente".

${ }^{114}$ Nota, cit., ap. 30.
} 
brán de adoptarse para mitigar los daños derivados de la superveniencia del supuesto de fuerza mayor; la posibilidad de requerir la renegociación del contrato, de suspender su vigencia, o incluso de resolverlo, a instancia de cualquiera de las partes, cuando se den determinadas situaciones y, en su caso, mediante el pago de una cantidad; los criterios que habrán de aplicarse, en su caso, para liquidar la relación; la posibilidad u obligación de contratar seguros que cubran el riesgo de obstáculos sobrevenidos al normal cumplimiento de los contratos, etc.

\section{E) El carácter insuperable o inevitable de los impedimentos.}

57. Como sabemos, no pueden ser calificados como sucesos de fuerza mayor aquellos eventos que, aun siendo extraños en su origen a la esfera de control del deudor, pueden ser "razonablemente" superados o evitados en su incidencia impeditiva del cumplimiento si el deudor despliega la diligencia que le es exigible a tenor de las circunstancias. En el contexto de la actual crisis, es importante insistir en que ni la propia enfermedad, ni las medidas adoptadas para contenerla, ni las posibles dificultades "generales" derivadas de la crisis económica, pueden considerarse por sí mismas como eventos impeditivos del cumplimiento exacto de las obligaciones, ya que ello dependerá de las circunstancias de cada caso concreto y, en particular, del tipo de prestación comprometida.

58. Como señala la $N o t a^{115}$, la enfermedad en sí misma podrá considerarse como un impedimento insuperable para el cumplimiento de las obligaciones de carácter personalísimo, cuando aquella afecte al propio deudor o a aquellas personas cuyo concurso personal sea imprescindible para la realización de la prestación de que se trate. Con todo, las circunstancias del caso podrán matizar este planteamiento, en función, p. ej., de que la enfermedad sea o no asintomática, o de que la prestación comprometida pueda o no ser cumplida, p. ej., alterando la modalidad de cumplimiento en algún aspecto no esencial (p. ej., sustituyendo una actividad presencial por otra on line). Con las mismas matizaciones, el cumplimiento de este tipo de obligaciones también podrá verse impedido, no solo por la enfermedad del deudor, sino por la sujeción de este a medidas de cuarentena o de confinamiento que le impidan desplazarse al lugar de realización de la prestación o entrar en contacto con otras personas.

59. En condiciones normales, la enfermedad del deudor ${ }^{116}$ o de quienes han de colaborar con él en el cumplimiento de las obligaciones asumidas (dependientes, auxiliares, etc.) no debería constituir un impedimento insuperable para el cumplimiento de obligaciones de carácter no personalísimo, ya que, en términos generales, cabría razonablemente esperar del deudor que este adoptase las medidas necesarias para superar el obstáculo, p. ej., recurriendo a los servicios de terceros ${ }^{117}$. Cabe pensar, no obstante, que en las actuales circunstancias podrá darse con mayor facilidad el caso de que el deudor se encuentre con dificultades adicionales que normalmente no se darían para encontrar esas vías alternativas de cumplimiento; y así, p. ej., si bien la enfermedad de un empleado del deudor no debería constituir, en general,

\footnotetext{
${ }^{115}$ Nota, cit., ap. 15 .

${ }^{116}$ Se advierte en la Nota (ap. 15, n. 12), que la consideración de la enfermedad derivada del coronavirus como evento impeditivo del cumplimiento, pese a tratarse de un problema subjetivo del deudor y no de un obstáculo externo y objetivo, se justifica porque se trata de una pandemia de carácter excepcional, y no de una enfermedad "ordinaria" del deudor (como podría ser, p. ej., una apendicitis), que, según se dice, "normalmente no sería considerada como fuerza mayor, ya que tales acontecimientos son parte de los riesgos ordinarios asumidos por las partes contractuales".

${ }^{117}$ En este sentido, CARrasco, Derecho de contratos..., cit., p. 951 . V. STS de 19 mayo 2015 (RJ 3118), cuando señala: "La imposibilidad subjetiva que se invoca no puede calificarse de imprevisible, pues las contingencias relacionadas con la salud, bien de la parte contratante o de su núcleo familiar, con afectación de su solvencia, son previsibles, según es notorio por máximas de experiencia. Las situaciones de invalidez o el fallecimiento, a causa de un accidente, son inevitables, pero no sus consecuencias, como también se colige de máximas de experiencia, siendo notorio cómo en caso de comprometerse la parte compradora, normalmente de vivienda, al pago aplazado de la adquisición, suele concertar un contrato de seguro que cubra el siniestro descrito, a fin de evitar la insolvencia a que se ha hecho mención". Adviértase, no obstante, que en este tipo de casos podrán ser de aplicación normas específicas que permitan al Tribunal modificar algún extremo del contrato en atención a la situación del deudor, como el ya citado art. 11 de la Ley de Venta a Plazos o el art. 1124.3 CC.
} 
un impedimento insuperable -ni tampoco imprevisible- para el cumplimiento de las obligaciones asumidas, en la actual situación puede darse el caso de que la enfermedad de un trabajador obligue a poner en cuarentena a toda la plantilla de la empresa para prevenir posibles contagios, privando así al empresario deudor de cualquier capacidad razonable de respuesta.

60. Un razonamiento similar sería aplicable a aquellos impedimentos para el cumplimiento que deriven de las medidas adoptadas por las autoridades para combatir la pandemia. Las dificultades derivadas, p. ej., de las limitaciones impuestas al desplazamiento de trabajadores, al transporte de mercancías, al tráfico o exportación de ciertos bienes, o al desarrollo de determinadas actividades, que podrían, en condiciones normales, ser vencidas mediante el despliegue por parte del deudor de un mayor nivel de esfuerzo o sacrificio o mediante la asunción de costes adicionales (p. ej., buscando proveedores alternativos), pueden llegar a resultar insuperables en la actual coyuntura, habida cuenta del alcance prácticamente universal que en muchos casos han asumido las restricciones adoptadas, que con frecuencia tienen incluso una proyección internacional. En determinados sectores de actividad, como la restauración, el turismo, los transportes, los espectáculos y otros, la paralización impuesta por las autoridades podrá considerarse como fuerza mayor impeditiva del cumplimiento, bien con carácter temporal o, incluso, con carácter definitivo ${ }^{118}$. En otros ámbitos, en cambio (p. ej., en el caso de venta de bienes a distancia), tales medidas podrán suponer un obstáculo temporal para el cumplimiento, pero difícilmente justificarán un incumplimiento definitivo. En ciertos sectores, incluso (como los relacionados con la prestación de bienes o servicios digitales), las medidas en cuestión no constituirán, en condiciones normales, un impedimento relevante para el cumplimiento puntual de las obligaciones asumidas. Sin embargo, también en estos supuestos habrá que estar a las circunstancias del caso concreto.

61. En condiciones normales, resultaría igualmente razonable entender que solo aquellas medidas restrictivas que tuvieran carácter obligatorio deberían ser consideradas como impedimentos insuperables para el cumplimiento ${ }^{119}$. Entendemos, no obstante, que, en las circunstancias de la actual pandemia, este es un dato que habrá de ser manejado con especial cuidado. El hecho de que las autoridades opten en un momento dado por recomendar ciertas medidas, en lugar de imponerlas como obligatorias, puede responder a razones de diverso tipo (de carácter económico, social, político, o incluso legal o competencial); pero, en nuestra opinión, y apelando al principio de precaución que debe imperar en todos aquellos ámbitos en que están en juego la vida y la salud de las personas (y más ante un situación extrema como la que estamos atravesando), parece que la conveniencia de cumplir las recomendaciones formuladas por las autoridades (en beneficio, no solo del propio deudor, sino también del propio acreedor y, en último término, del interés general) podrá considerarse, en muchos casos, como un impedimento del cumplimiento susceptible de ser calificado como fuerza mayor, al menos en un sentido impropio, en la medida en que podría fundamentar, cuando menos, la inexigibilidad de la conducta de cumplimiento ${ }^{120}$. Cuestión distinta será determinar en qué medida una prohibición que solo limita parcialmente las posibilidades de actuación del deudor, dejando un margen para que este pueda continuar con su actividad (como ha sucedido, p. ej., con la posibilidad, reconocida a los establecimientos hosteleros, de mantener el servicio de comidas

\footnotetext{
${ }^{118} \mathrm{~V}$. al respecto algunas de las medidas de emergencia adoptadas en relación con la imposibilidad de cumplimiento de determinados contratos de consumo, a las que se hace referencia supra, I.2, aps. 9-11.

${ }^{119}$ Nota, cit. ap. 16.

${ }^{120}$ En relación con los impedimentos derivados de la crisis del coronavirus, distingue CARrasco ("Permítame...", cit., pp. 6-7) entre contingencias "propias" de fuerza mayor (prohibición normativa de que se pueda realizar en sus propios términos la prestación convenida; prohibición normativa de que se pueda realizar una actividad que es instrumental necesariamente para la consecución de la prestación comprometida; imposibilidad absoluta individual de cumplir sin culpa propia, p. ej., en una prestación de servicios cuando el obligado se ha infectado; imposibilidad absoluta genérica de cumplir por parte de cualquier deudor que estuviera situado en las condiciones del deudor, p. ej. todos los proveedores de esa clase) y contingencias "impropias" de fuerza mayor (inexigibilidad de una conducta de cumplimiento, porque este comprometería recursos personales del deudor con razonable probabilidad de exposición a la infección; inexigibilidad de una conducta de cumplimiento, porque este comprometería recursos personales de la contraparte, con razonable probabilidad de exposición a la infección; inexigibilidad de una conducta de cumplimiento que comportaría un sobrecoste extraordinario no compensado por el precio del contrato; imposibilidad no absoluta, pero singular del deudor, de cumplir en tiempo y forma; y desaparición sobrevenida de la causa).
} 
para llevar) podrá o no servir de base para apreciar la concurrencia de un impedimento constitutivo de fuerza mayor respecto al cumplimiento de las obligaciones asumidas, lo que necesariamente habrá de determinarse, una vez más, a la vista de las circunstancias del caso concreto.

62. Por lo demás, es previsible que en el marco de la actual crisis se den con frecuencia situaciones en las que tanto la propia enfermedad, como las medidas individuales o generales de contención, o los efectos de la crisis económica derivada, sitúen al deudor, no ante una imposibilidad absoluta para cumplir, pero sí ante una situación de dificultad extraordinaria o exorbitante, susceptible de justificar, según los casos, la activación de instrumentos tales como la exoneración o liberación del deudor por fuerza mayor "impropia", la limitación en cuanto a la exigibilidad del cumplimiento por parte del acreedor conforme a la buena fe, la terminación de los contratos por frustración de su finalidad, su renegociación o revisión judicial por excesiva onerosidad sobrevenida, etc. ${ }^{121}$ En el caso concreto de la fuerza mayor, esta flexibilidad aplicativa vendría avalada por la noción amplia de "impedimento" que manejan los Principios de Unidroit y, en el ámbito del CC español, por la interpretación amplia acogida en ocasiones por la jurisprudencia acerca del propio concepto de imposibilidad sobrevenida. Por nuestra parte, entendemos que el manejo de criterios flexibles en este punto puede resultar especialmente aconsejable en el presente contexto, teniendo en cuenta la excepcionalidad de la situación y el extraordinario e inusitado alcance de los obstáculos que se plantean en muchos casos a la hora de dar un cumplimiento exacto a las obligaciones asumidas.

63. Presumiblemente, los impedimentos para el cumplimiento de los contratos relacionados con la pandemia o con las medidas de contención adoptadas tendrán en muchos supuestos un carácter temporal, lo que, en su caso, justificará que los eventuales efectos exoneratorios o liberatorios para el deudor tengan igualmente un carácter temporal (tal como se prevé en el art. 7.1.7 (4) de los Principios, y tal como ha admitido también nuestra jurisprudencia ${ }^{122}$ ). Esta, en principio, sería la solución más deseable desde el punto de vista del interés general, ya que contribuiría a preservar el entramado contractual preexistente, tan necesario para la futura reactivación económica. En no pocos casos, sin embargo, cabe pensar que la propia incertidumbre existente en cuanto a la posible duración de la crisis sanitaria y de las correspondientes medidas restrictivas (susceptibles de verse prorrogadas o reactivadas en función de la evolución de las circunstancias) podrá justificar la definitiva extinción de las relaciones contractuales afectadas, al no ser viable imponer a ninguna de las partes una suspensión de duración indefinida. Por otro lado, la propia incertidumbre de la situación generada por la pandemia permite subrayar la utilidad de la previsión contenida en el propio art. 7.1.7 de los Principios, según la cual el deudor afectado por un impedimento temporal deberá contar con un plazo adicional para cumplir cuya duración habrá de ser "razonable", y no necesariamente coincidente con la duración del propio impedimento: la propia naturaleza de las medidas de contención adoptadas, en cuanto pueden implicar una paralización casi absoluta -aunque temporal-, y en ocasiones indefinida, de la actividad en determinados sectores, impondrán habitualmente la necesidad de reconocer a los deudores afectados un plazo adicional para cumplir razonablemente amplio, una vez que se hayan levantado las medidas relevantes, con objeto de permitir la recuperación de los niveles normales de actividad ${ }^{123}$.

\section{Los deberes adicionales impuestos a las partes}

\section{A) La obligación de notificar al acreedor la existencia del impedimento}

64. El art. 7.1.7 (3) de los Principios dispone: "El deudor debe notificar al acreedor la existencia del impedimento y sus consecuencias sobre su capacidad para cumplir. Si la notificación no llega a su

${ }^{121}$ Sobre la frustración del fin del contrato y su delimitación respecto a la excesiva onerosidad sobrevenida, v. infra, III.3. A) y B).

${ }^{122}$ V. supra, II.3, ap. 40.

${ }^{123}$ Nota, cit., ap. 27. 
destino en un plazo razonable a partir del momento en que tuvo, o habría debido tener, conocimiento del impedimento, el deudor está obligado a indemnizar los daños y perjuicios derivados de la falta de recepción". Se trata, probablemente, de la diferencia más relevante que media entre la regulación de la fuerza mayor en los Principios y en el CC, donde no existe ninguna previsión equivalente, ni en el art. 1105, ni en los preceptos que regulan la imposibilidad sobrevenida de la prestación no imputable al deudor; lo cual no excluye que, en atención a las circunstancias del caso concreto, pueda considerarse como un deber que incumbe al deudor, y que integra el contenido del contrato por exigencias del principio de buena fe (arts. 7.1 y $1258 \mathrm{CC}$ ).

65. No se trata de una carga impuesta al deudor como requisito para poder hacer valer el efecto liberatorio o exoneratorio de la fuerza mayor: concurriendo esta, dicho efecto opera aunque el deudor no formule la correspondiente notificación; pero deberá indemnizar los daños causados al acreedor, no ya por la falta de cumplimiento, sino por la falta de notificación (o por la falta de recepción de la notificación remitida en un plazo razonable). La Nota ${ }^{124}$ identifica los daños indemnizables en tal caso con el "daño de confianza" que pueda experimentar el acreedor, de tal manera que la indemnización habrá de servir para poner a aquel en la misma situación que tendría si hubiera recibido la notificación a tiempo.

66. Se trata, en todo caso, de una previsión perfectamente razonable, ya que trata de evitar que, ante la concurrencia de un evento impeditivo del cumplimiento de su obligación, el deudor pueda limitarse a mantener una postura meramente pasiva, esperando a que el acreedor reclame el cumplimiento para, solo entonces, plantear la correspondiente oposición. Si la fuerza mayor exonera al deudor de toda responsabilidad por su incumplimiento, es justo que se le imponga el deber de notificar al acreedor la existencia del impedimento y sus consecuencias sobre la obligación asumida. De este modo se facilita al acreedor la posibilidad de adoptar las medidas más oportunas para evitar o, al menos, minimizar los daños que puedan derivarse de la falta de cumplimiento, ya sea buscando una solución alternativa (p. ej., un suministro de reemplazo), o incluso renegociando los términos del acuerdo entre las mismas partes.

67. Teniendo en cuenta el fundamento de la norma, parece razonable entender, como hace la Nota, que la obligación de indemnizar los daños derivados de la falta o retraso en la notificación podrá verse limitada en aquellos casos en que la existencia del impedimento sea o debiera ser conocida por el acreedor. Habría que matizar, no obstante, que, a estos efectos, no ha de considerarse decisivo el hecho de que el evento impeditivo sea de conocimiento público (como sucede, en el caso que nos ocupa, con la situación de pandemia o las medidas de contención adoptadas), ya que lo relevante será determinar la incidencia que dicha circunstancia tiene, en el caso concreto, sobre la capacidad de cumplimiento del deudor. Siendo este un extremo respecto del cual, en condiciones normales, el deudor tendrá un conocimiento más preciso, detallado e inmediato que el acreedor (lo que, por otra parte, explica que se atribuya a aquel la carga de la prueba al respecto), difícilmente podrá justificarse la falta de notificación por no ser necesaria.

68. Por lo demás, aunque los Principios no aluden a ello, cabe pensar que, en aquellos casos en que el impedimento para el cumplimiento tenga un carácter meramente temporal, la parte afectada por dicho impedimento también deberá notificar a la otra el cese de dicho impedimento y su disposición para reiniciar el cumplimiento del contrato, una vez transcurrido el "periodo razonable" de exención al que se refiere el art. 7.1.7 (4).

\section{B) El deber del acreedor de mitigar el daño}

69. Se recuerda en la $N t^{125}$ que, por aplicación de la regla general establecida en el art. 7.4.8 de los Principios, el acreedor, ante una situación de incumplimiento de la obligación por parte del deu-

\footnotetext{
${ }^{124}$ Nota, cit., ap. 25.

${ }^{125}$ Nota, cit., ap. 26.
} 
dor, tampoco puede limitarse a adoptar una actitud pasiva, sino que debe hacer lo necesario para mitigar los daños derivados del incumplimiento, ya que, según establece aquel precepto en su apartado (1), "la parte incumplidora no es responsable del daño sufrido por la parte perjudicada en tanto que el daño pudo haber sido reducido si esa parte hubiera adoptado medidas razonables". Añade el apartado (2) que "la parte perjudicada tiene derecho a recuperar cualquier gasto razonablemente efectuado en un intento por reducir el daño"; lo que parece implicar que podrá reclamarse el reembolso de tales gastos aun cuando, finalmente, el intento de reducir el daño haya resultado fallido.

70. Aunque en el CC no existe una previsión similar de carácter general, se entiende que, por aplicación del principio de buena fe (y, en ocasiones, por expresa previsión legal, como la del art. 17 de la Ley 50/1980, del Contrato de Seguro, o la del art. 77 del Convenio de Viena ${ }^{126}$ ), el acreedor tiene la carga de aminorar las consecuencias dañosas del incumplimiento, de tal manera que en ningún caso podrán imputarse al deudor los daños que, teniendo su origen en el incumplimiento, podían haber sido evitados por el acreedor si hubiera actuado con la diligencia exigible a tenor de las circunstancias ${ }^{127}$.

71. A primera vista, el deber de atenuar el daño al que se refieren los Principios solo tendría sentido ante una situación de incumplimiento contractual que permitiese al acreedor exigir la correspondiente responsabilidad al deudor, y no cuando este pueda acogerse a la fuerza mayor para exonerarse de responsabilidad por la falta de cumplimiento. Sin embargo, dicho deber adquiere también sentido en este último supuesto si se pone en relación con el deber del deudor de notificar a aquel la existencia de un impedimento para el cumplimiento, tal como vimos en el epígrafe anterior. Dicho de otro modo, tratándose de un supuesto de fuerza mayor, los únicos daños que, en principio, podrán imputarse al deudor serán aquellos que haya podido sufrir el acreedor como consecuencia del incumplimiento por aquel del deber de notificarle la existencia de un impedimento para el cumplimiento; $y$, si bien el acreedor no podrá reclamar aquellos daños que podía haber evitado adoptando las medidas razonables, cabe pensar que estas solo le serán exigibles, como regla, desde el momento en que se le haya notificado la existencia del impedimento y su incidencia sobre la capacidad de cumplir del deudor (a menos, como vimos, que pueda probarse que el acreedor tuvo o pudo tener conocimiento de tales circunstancias por otra vía).

\section{C) Principio de buena fe y deber de cooperación entre las partes}

72. Los arts. 1.7 y 5.1 .3 de los Principios formulan, con carácter general, el principio de buena fe y lealtad y el deber de cooperación que incumbe a cada una de las partes a la hora de facilitar el cumplimiento de la otra. En el sistema del CC español, este deber de cooperación entre partes, aunque no aparece formulado de manera expresa, sí se considera como una consecuencia natural del principio de buena fe, al que se refieren especialmente el art. 7.1 y, en el ámbito contractual, el art. 1258. Se trata, como es sabido, de un principio esencial e inderogable dentro de cualquier sistema jurídico, como se pone claramente de manifiesto a la vista del art. 1.7 (2) de los Principios, en el que se establece que las partes no pueden excluir ni limitar el deber de actuar con buena fe y lealtad negocial en el comercio internacional. Pero se trata, obviamente, de principios que adquieren una especial significación y trascendencia en una situación como la actual, en la que prácticamente todas las relaciones económicas y jurídicas han de verse afectadas en mayor o menor medida por una crisis imprevisible, de proporciones mundiales, de extraordinaria gravedad, y de incierta evolución, y en la que, por tanto, parece especialmente exigible -también a nivel jurídico- que todos los sujetos implicados en tales relaciones contribuyan a superar

\footnotetext{
${ }^{126}$ Al que España se adhirió por Instrumento de ratificación de 17 julio 1990 (BOE de 30 enero 1991).

${ }^{127}$ En este sentido, v., p. ej., STS de 14 mayo 2003 (RJ 4749); y GREGORACI, op. cit., pp. 461-462, donde recuerda que una expresa previsión al respecto se recoge en el art. 1211 de la Propuesta para la Modernización del Código Civil de la CGC. Sobre las medidas "proactivas" que pueden adoptar las empresas para anticipar, prevenir y mitigar los potenciales daños que puedan derivar de la crisis del coronavirus mediante una planificación adecuada de la actividad, v. Rivera, op. cit., esp. pp. 4 y 5.
} 
en lo posible las dificultades generadas por la crisis, más allá incluso de lo que sería "razonablemente" exigible en circunstancias normales, no solo facilitando el cumplimiento de la otra parte, sino también preservando en lo posible los intereses de esta, mitigando los daños derivados de una posible situación de fuerza mayor, o aviniéndose a renegociar de buena fe, en su caso, los términos del contrato ${ }^{128}$.

\section{Posibilidad de acudir a otros remedios}

73. El régimen de la fuerza mayor establecido por el art. 7.1.7 de los Principios exonera al deudor de la responsabilidad por los daños derivados del incumplimiento, cuando se den las circunstancias anteriormente examinadas ${ }^{129}$; pero deja a salvo los demás remedios que puedan corresponder a las partes ante la falta de cumplimiento del contrato, siempre que se den los respectivos requisitos ${ }^{130}$. En concreto, dispone el apartado (4) que "las disposiciones del presente artículo no impiden a las partes ejercitar su derecho de resolver el contrato, suspender el cumplimiento de sus obligaciones o exigir intereses por las sumas debidas".

74. A la facultad de suspender el cumplimiento de las propias obligaciones ante el incumplimiento de la otra parte se refiere el art. 7.1.3 de los Principios en los siguientes términos: "(Suspensión del cumplimiento) (1) Cuando las partes han de cumplir simultáneamente, cada parte puede suspender el cumplimiento de su prestación hasta que la otra ofrezca su prestación. (2) Cuando las partes han de cumplir de modo sucesivo, la parte que ha de cumplir después puede suspender su cumplimiento hasta que la parte que ha de hacerlo primero haya cumplido"131. Se trata, por tanto, de un régimen sustancialmente coincidente con el que, en el ordenamiento español, se asocia al funcionamiento de la exceptio non adimpleti contractus en el ámbito de las obligaciones sinalagmáticas; figura que carece de una regulación general en el CC, pero sí está presente en numerosos supuestos concretos (arts. 1100.3, $1466,1467,1500,1502,1308$, etc.), por lo que la doctrina y la jurisprudencia le reconocen un alcance general ${ }^{132}$. Es importante destacar que, en el sistema del CC, se entiende que la posibilidad de oponer la exceptio -tanto por vía judicial como extrajudicial- no está supeditada a la concurrencia de dolo o culpa en el incumplimiento de la otra parte; pero sí se requiere que su ejercicio se atenga a las exigencias derivadas de la buena fe, lo que excluye su viabilidad, p. ej., cuando el que la invoca ha provocado el incum-

${ }^{128}$ Para el sistema del CC, señala CARRASco (Derecho de contratos..., cit., p. 961) que la concurrencia de un supuesto de caso fortuito liberatorio para el deudor puede ser, a su vez, fuente y fundamento, conforme a la ley o a las exigencias de la buena fe, para otras obligaciones secundarias, como las relacionadas con la protección de los intereses de la otra parte, la mitigación de los daños derivados de la falta de cumplimiento, o la búsqueda de una salida negociada a la situación generada por el caso fortuito; respecto a esta última cuestión, recuerda el autor que el deber de negociar de buena fe una salida alternativa es un pacto absolutamente común en todos los contratos comerciales que contemplan el riesgo de la fuerza mayor.

${ }^{129}$ Así lo aclara el Comentario, cit., p. 241. V. también art. 7.4.1 de los Principios: "(Derecho al resarcimiento) Cualquier incumplimiento otorga a la parte perjudicada derecho al resarcimiento, bien exclusivamente o en concurrencia con otros remedios, salvo que el incumplimiento sea excusable conforme a estos Principios". Como señala Llamas Pombo (op. cit., 1.892), se trata del mismo planteamiento que cabe extraer del régimen español acerca de las consecuencias del caso fortuito: el deudor se libera de responsabilidad, pero sin que ello haya de privar al acreedor de la posibilidad de acudir a otros remedios frente al incumplimiento.

${ }^{130}$ Nota, cit., ap. 29. Precisamente, el hecho de que la concurrencia de un supuesto de fuerza mayor, aun exonerando de responsabilidad al deudor, no impida a la otra parte recurrir a otros remedios, como la resolución del contrato, es el principal inconveniente que subraya Morales Moreno (op. cit., p. 449) respecto a la utilización de aquel mecanismo en el contexto de la actual crisis, ya que el recurso generalizado a la resolución puede privar al sistema económico "del entramado de contratos sobre los que el mismo se desenvuelve, cuya conservación facilitará la futura reactivación de la actividad económica", contribuyendo asimismo a agudizar los problemas de liquidez de los sujetos afectados. Por ello, entiende el autor que la intervención del legislador en el momento actual debería contribuir a evitar o limitar el recurso a la resolución.

${ }^{131} \mathrm{La}$ facultad de suspender el propio cumplimiento también aparece prevista en los arts. 7.1.4 (4), 7.1.5 (2) y 7.3.4, dedicados, respectivamente, a los casos de subsanación del incumplimiento de la otra parte, a aquellos en que se concede al deudor un periodo suplementario para el cumplimiento, y a los supuestos en que, creyendo razonablemente una de las partes que la otra incumplirá esencialmente su obligación, reclame una garantía adecuada de cumplimiento, en tanto dicha garantía no sea otorgada.

${ }^{132}$ SSTS de 18 mayo 2012 (RJ 6358) y 15 marzo 2016 (RJ 841). 
plimiento de la otra parte, o cuando dicho incumplimiento se refiere a prestaciones secundarias o carece de suficiente entidad para justificar una negativa a cumplir íntegramente la prestación demandada ${ }^{133}$.

75. En cuanto a la resolución, el art. 7.3.1 de los Principios la regula como un remedio que el acreedor tiene a su disposición, concretamente, en aquellos casos en que el incumplimiento de la otra parte sea esencial, conforme a los criterios establecidos por el propio precepto; criterios entre los cuales se mencionan, p. ej., el hecho de que el incumplimiento prive sustancialmente a la parte perjudicada de lo que tenía derecho a esperar según el contrato (a menos que la otra parte no hubiera previsto ni podido prever razonablemente ese resultado), que la ejecución estricta de la prestación fuera esencial según el propio contrato, que la parte perjudicada tenga razones para desconfiar de que la otra cumplirá en el futuro, o, en el caso de demora, que la parte incumplidora no realice su prestación antes del vencimiento del plazo suplementario que se le hubiera concedido ${ }^{134}$. Se trata de un planteamiento similar al que se sigue en la doctrina y la jurisprudencia española, que -con alguna salvedad a la que inmediatamente se hará referencia- reconocen que, en las obligaciones recíprocas, el incumplimiento de la obligación que incumbe a una de las partes, cuando tenga un carácter esencial ${ }^{135}$, permite a la otra resolver el contrato, no solo cuando el incumplimiento sea imputable (supuesto al que se refiere directamente el art. 1124 $\mathrm{CC}$ ), sino también cuando derive de un supuesto de imposibilidad sobrevenida no imputable ${ }^{136}$.

76. Obsérvese, por otra parte, que cuando el art. 7.3.1 (4) de los Principios, en los casos de fuerza mayor, reconoce la posibilidad de ejercitar otras acciones, no alude exclusivamente al acreedor, sino "a las partes". Ello permite entender que, llegado el caso, la resolución del contrato basada en la concurrencia de un supuesto de fuerza mayor podrá ser instada, no solo por el acreedor, sino también por el propio deudor directamente afectado por el impedimento para cumplir, con objeto de liberarse definitivamente de cualquier responsabilidad por el incumplimiento. Aunque en el sistema del Derecho español la legitimación para el ejercicio de la acción por resolución (sea por incumplimiento o por imposibilidad sobrevenida no imputable) suele afirmarse habitualmente respecto al acreedor, lo cierto es que, en la práctica, la legitimación del deudor imposibilitado para cumplir ha sido también reconocida por los Tribunales en diferentes ocasiones, pese a la repetida declaración según la cual el deudor no cumplidor no puede instar la resolución ${ }^{137}$.

77. La inclusión del apartado (4) en el precepto dedicado, precisamente, a la fuerza mayor, permite afirmar que, en el sistema diseñado por los Principios, se opta por un criterio unívoco en cuanto a la atribución de lo que en España se suele denominar "el riesgo del caso fortuito en las obligaciones sinalagmáticas": el deudor imposibilitado para cumplir por una circunstancia de fuerza mayor se libera de su obligación y se exonera de responsabilidad, pero, cuando ello implique un incumplimiento esencial, el acreedor puede siempre resolver el contrato ${ }^{138}$, sea cual sea la naturaleza de las prestaciones debidas,

${ }^{133}$ Entre otras, SSTS de 29 abril 1994 (RJ 2982) y 22 diciembre 2006 (RJ 2007/307). V. GonZÁlez PaCANowsKa, I., "Artículo 1124", en Bercovitz Rodríguez-Cano, R. (dir.), Comentarios al Código Civil, t. VI, ed. Tirant lo Blanch, Valencia, 2013, pp. 8.244 y 8.235 , donde advierte que los criterios conforme a los cuales ha de determinarse cuándo resulta justificado oponer la $e x$ ceptio no tienen por qué coincidir con los -más rigurosos- que han de aplicarse para determinar la procedencia de la resolución.

${ }^{134}$ Como se advierte en el Comentario, cit., p. 242, la fuerza mayor, como la excesiva onerosidad sobrevenida, será típicamente relevante, en especial, en los contratos de larga duración; y, si bien es en el caso de excesiva onerosidad donde se incentiva especialmente la renegociación entre las partes para mantener la vigencia del contrato, también cabe la posibilidad de que, en este tipo de contratos (donde es posible que las inversiones realizadas solo puedan recuperarse con el paso del tiempo), las partes hayan anticipado la eventualidad de un suceso de fuerza mayor, con objeto de favorecer la continuidad del contrato, en la medida de lo posible, a través de diversos mecanismos, de manera que la resolución quede como un último recurso.

${ }^{135}$ Por todas, STS de 22 diciembre 2014 ( $R J$ 6406).

${ }^{136}$ Sobre la procedencia de la resolución cuando el incumplimiento de la otra parte se debe a imposibilidad sobrevenida de la obligación por causa no imputable al deudor -aunque con exclusión de la indemnización de daños-, v. SSTS de 9 octubre 2006, 22 diciembre 2014 ( $R J$ 6406) y 26 abril 2018 ( $R J 2192$ ), con cita de otras. En la doctrina, v., por todos, GonZÁLez PACANOWSKA, Comentarios..., cit., pp. 8.224-8.225.

${ }^{137}$ Lo advierte CARRASCo (Derecho de contratos..., cit., p. 936 y n. 21, citando como ejemplos las SSTS de 7 febrero 1994 (RJ 917) y 23 febrero 1994 ( $R J$ 1995/683). V. también GonzÁlez Pacanowska, Comentarios ..., cit., p. 8.225.

${ }^{138}$ La necesidad de instar la resolución del contrato -sea por vía judicial o extrajudicial- en estos casos contrasta con la automática resolución del contrato prevista en el art. 9:303 (4) de los PECL: "Si una parte está exonerada conforme al art. 8:108 
con objeto de liberarse de su propia obligación y repetir, en su caso, lo ya pagado (con el único límite del enriquecimiento obtenido). En el sistema español, se admite que este es el criterio aplicable con carácter general en los contratos sinalagmáticos (v., p. ej., arts. 1585, 1589, 1590 y 1595, relativos al contrato de obra $)^{139}$, con la importante -y discutida- excepción de la venta de cosa determinada, en la que la doctrina mayoritaria entiende (con base en la interpretación a contrario del poco claro art. $1452 \mathrm{CC}$ ) que el riesgo de la pérdida, destrucción o deterioro fortuito de la cosa debida se atribuye al comprador ${ }^{140}$. En principio, parece claro que no es este último un supuesto que, previsiblemente, vaya a plantearse con frecuencia como consecuencia derivada de la crisis del COVID-19, que, en todo caso, podrá afectar al cumplimiento regular de las obligaciones de dar cosa determinada de otros modos (p. ej., retrasando o dificultando el cumplimiento de la obligación de entrega, imponiendo de forma sobrevenida prohibiciones legales de comercialización o transporte respecto a ciertos tipos de bienes, etc.); hipótesis todas ellas en las que será aplicable la regla general de atribución del riesgo al deudor ${ }^{141}$, permitiendo al acreedor liberarse de

por un impedimento que es total y permanente, el contrato queda resuelto automáticamente y sin necesidad de notificación en el momento en que surge el impedimento". El art. 7.1.7 de los Principios no se refiere directamente a esta cuestión, aunque el art. 7.3.2 (1), al regular la resolución por incumplimiento esencial, dispone que el derecho a resolver el contrato "se ejercita mediante una notificación a la otra parte”. En nuestra doctrina, GonZÁlEZ PACANOWSKa (Comentarios..., cit.), recuerda que, en principio, la resolución por imposibilidad sobrevenida no opera de forma automática, aunque advierte que, en algunos casos, sí puede entenderse que la disolución del vínculo se producirá sin necesidad de declaración al respecto (p. ej., en caso de destrucción de la cosa arrendada, art. 28.1 LAU 1994, o de muerte del contratista, art. 1595 CC).

${ }^{139}$ Por todos, Carrasco, Derecho de contratos..., cit., p. 934. A propósito de esta cuestión, en los últimos meses se ha planteado un interesante debate acerca de la incidencia de la crisis del coronavirus sobre los contratos de arrendamiento de locales de negocio, con dos posturas abiertamente enfrentadas: la de CARrasco ("Permítame...". cit., p. 9; y también en "Locales de negocio cerrados por Covid: la barbarie o el lobby hacen su agosto", en Publicaciones Jurídicas, Centro de Estudios de Consumo, 22 abril 2020, pp. 1 y ss.), para quien la imposibilidad de usar los locales arrendados conforme a su destino como consecuencia de una prohibición legal vinculada a las medidas anti-Covid exime al arrendatario de la obligación de pagar la renta (pudiendo suspender el pago o, incluso, resolver el contrato), por cuanto es obligación principal del arrendador la de mantener al arrendatario en el goce pacífico de la cosa arrendada; y la de PANTALEÓN (“Arrendamiento...", cit., pp. 7-8), para quien "los riesgos que el propietario arrendador de una cosa, a diferencia del vendedor, mantiene a su cargo o continúa soportando son, típicamente, los riesgos afectantes a la cosa arrendada en sí, que, de realizarse, impedirían el goce pacífico de la misma por el arrendatario. A esa idea responde, como es evidente, el art. 26 LAU (...). El arrendador no mantiene ni asume los riesgos afectantes a la utilidad a extraer por el arrendatario de dicho goce (...). El arrendador de un local de negocio no se obliga a (ni menos aún garantiza) que el arrendatario comience o pueda continuar ejerciendo la referida actividad empresarial. Si ello sucede por una razón ajena al local arrendado -que no afecte a la estructura, los elementos constructivos, la habitabilidad o la funcionalidad del referido local en sí-, de ningún modo cabe afirmar que el arrendador incumple la obligación que le impone el art. $1554.3^{\circ} \mathrm{CC}$ ". El autor descarta que en el caso discutido las medidas prohibitivas puedan constituir un supuesto de fuerza mayor impeditiva del cumplimiento de las obligaciones contractuales, sin perjuicio de que, en su caso, se pueda plantear un problema de excesiva onerosidad sobrevenida susceptible de justificar la aplicación de la doctrina de la cláusula rebus sic stantibus (pp. 9-10). De acuerdo con la primera postura se pronuncia, p. ej., Bercovitz, "Incidencia...", cit., p. 6; en favor de la segunda, v., p. ej. GrEGORACI, op. cit., p. 478. Sin ánimo de terciar en la cuestión, quizá pueda resultar útil recordar el precedente de la STS de 10 diciembre 1963 ( $R J 5220$ ), en la que se entendió que incumbía a la parte arrendadora la obligación de saneamiento respecto a las "perturbaciones de derecho" procedentes de tercero que pudieran impedir el goce pacífico de la cosa por el arrendatario (arts. $1554.3^{\circ}$ y $1560.2 \mathrm{CC}$ ), y recondujo a este ámbito un caso en que determinadas monterías de caza que habían sido objeto de arrendamiento fueron prohibidas por la Administración, permitiendo con ello la resolución del contrato por el arrendatario, y obligando al arrendador a restituir el precio recibido. Nótese, en todo caso, cómo la legislación de emergencia dictada en España en materia de arrendamientos urbanos, en cuanto prevé ciertas moratorias y suspensiones en interés de los arrendatarios de locales de negocio afectados por la crisis del coronavirus y sus derivaciones, parece partir del presupuesto de que, a falta de las medidas señaladas, el arrendatario seguiría obligado el pago de las rentas de forma incondicionada.

${ }^{140}$ Sobre las diferentes interpretaciones a propósito de este artículo, v. Ataz López, J., “Artículo 1452”, en Bercovitz Rodríguez-Cano, R. (dir.), Comentarios al Código Civil, t. VII, ed. Tirant lo Blanch, Valencia, 2013, pp. 10.235 y ss.

${ }^{141}$ Como señala CARRASco (Derecho de contratos..., cit., p. 940), "el supuesto de hecho único considerado en la regla de asignación de riesgos del art. 1452 CC es la pérdida de la cosa debida. No es ésta, sin embargo, la causa de imposibilidad más frecuente, siendo más comunes los casos de imposibilidad nacidos de hechos que impiden la entrega de la cosa no destruida, o las hipótesis en que la imposibilidad de cumplimiento del deber de entrega proviene de una sobrevenida modificación normativa. En ninguno de estos casos se aplica el art. 1452 CC, y la regla de asignación del riesgo vuelve a ser la genérica del art. 1124 CC, pudiendo el acreedor resolver el contrato por imposibilidad sobrevenida hasta el instante en que la prestación debida haya sido consumada mediante su entrega". En "Permítame...", cit., p. 4, el mismo autor recuerda que la hipótesis de pérdida o destrucción de la cosa debida "no parece que pueda darse en una contingencia de riesgo COVID-19". 
sus obligaciones (total o parcialmente, temporal o definitivamente) mediante la suspensión del propio cumplimiento o, incluso, mediante la resolución del contrato ${ }^{142}$.

78. A los remedios anteriormente señalados (suspensión de la propia prestación, resolución del contrato) añade el art. 7.1.7 (4) de los Principios una referencia específica al retraso en el cumplimiento de las obligaciones pecuniarias, reconociendo al acreedor, de forma incondicionada, el derecho a reclamar el pago de intereses por las sumas debidas. El tratamiento específico de las obligaciones de dinero -respecto de las cuales se excluye, a radice, la eventualidad de un incumplimiento excusable-, se ve confirmado por lo previsto en los arts. 7.2.1 y 7.4.9, que prevén, también de forma incondicionada, la facultad de reclamar el pago de las obligaciones de dinero, y la obligación de pagar intereses por el retraso $^{143}$. La correspondencia, en este caso, se da con el art. 1108 del CC español, donde se establece que "si la obligación consistiere en el pago de una cantidad de dinero, y el deudor incurriere en mora, la indemnización de daños y perjuicios, no habiendo pacto en contrario, consistirá en el pago de los intereses convenidos, y a falta de convenio, en el interés legal". En el sistema español, el régimen específico de las obligaciones pecuniarias se relaciona con la consideración de estas como el prototipo de las obligaciones genéricas, respecto de las cuales se descarta por principio la eventualidad de que lleguen a hacerse de imposible cumplimiento, por lo que el posible retraso del deudor (siempre que este haya incurrido en mora, bien de forma automática, o bien en virtud de la correspondiente interpelación del acreedor; cfr. art. 1100) dará lugar siempre a la obligación de indemnizar al acreedor en la cuantía correspondiente a los intereses, sin que haya lugar para alegar la eficacia exoneratoria de la fuerza mayor o el caso fortuito ${ }^{144}$; y todo ello sin perjuicio de que, en su caso, pueda alegarse la doctrina de la cláusula rebus sic stantibus para solicitar la revisión judicial del contrato cuando se den sus requisitos ${ }^{145}$.

\section{Excesiva onerosidad (hardship)}

\section{El deber de cumplir el contrato a pesar de la excesiva onerosidad sobrevenida y la adaptación o la resolución contractual como excepción en los PICC}

79. Los PICC abordan la excesiva onerosidad en la sección segunda del capítulo 6, dedicado al cumplimiento. La definición de hardship (art. 6.2.2) y los efectos de su concurrencia (art. 6.2.3) están

\footnotetext{
${ }^{142}$ En este sentido, Carrasco, Derecho de contratos..., cit., p. 941. En la jurisprudencia, v. SSTS de 19 enero 1990 (RJ 16), 7 febrero 1994 (RJ 917) y 11 noviembre 2003 (RJ 8290).

${ }^{143}$ Art. 7.2.1: "(Cumplimiento de obligaciones dinerarias) Si una parte que está obligada a pagar dinero no lo hace, la otra parte puede reclamar el pago”. Art. 7.4.9: “(Intereses por falta de pago de dinero) (1) Si una parte no paga una suma de dinero cuando es debido, la parte perjudicada tiene derecho a los intereses sobre dicha suma desde el vencimiento de la obligación hasta el momento del pago, sea o no excusable la falta de pago. (...) (3) La parte perjudicada tiene derecho a una indemnización adicional si la falta de pago causa mayores daños". Sobre el debate acerca de la posibilidad de reclamar la indemnización adicional a la que se refiere el ap. (3) citado en el sistema del CC, v. De PABLo, op. cit., p. 189.

${ }^{144}$ Precisamente, Morales Moreno (op. cit., p. 449) considera que la dificultad para aplicar el régimen de la fuerza mayor a las obligaciones pecuniarias constituye un serio inconveniente para su aplicación en las circunstancias actuales.

${ }^{145}$ SSTS de 25 mayo 1994 (RJ 6723), 13 julio 2017 (RJ 3962) y 19 mayo 2015 (RJ 3118). En esta última se dice expresamente que la imposibilidad liberatoria prevista en los arts. 1182 y $1184 \mathrm{CC}$ no es aplicable a las deudas de pago de dinero, tampoco cuando el deudor se ve afectado por una desgracia familiar (pérdida de ingresos como consecuencia del fallecimiento del esposo de la actora), y que tal circunstancia no puede considerarse como imprevisible, como lo demuestra el frecuente recurso a la concertación de seguros para cubrir la posible insolvencia sobrevenida; y añade: "Deviene necesario, pues, diferenciar entre la imposibilidad sobrevenida de cumplir la prestación, que sólo afecta a las obligaciones de entregar una cosa determinada o de hacer, pero no a las deudas pecuniarias, de aquellos supuestos en que la prestación resultase exorbitante o excesivamente onerosa, con encaje en la doctrina de la cláusula 'rebus sic stantibus'”. La STS de 13 julio 2017 (RJ 3962), tras recordar que la imposibilidad sobrevenida no es aplicable a las deudas de dinero, advierte que, en principio, tampoco puede el deudor exonerarse invocando la doctrina de la cláusula rebus sic stantibus en los casos en que se encuentre con dificultades para obtener financiación, ya que es esta una circunstancia que no puede considerarse, en general, como imprevisible, y es por tanto, salvo pacto en contrario, un riesgo del deudor. Un supuesto especial es el de la STS de 26 abril 2018 (RJ 2192), que considera extinguida por imposibilidad legal sobrevenida (conforme al art. 1184) la obligación, asumida por una empresa pública de transportes, de pagar la prima del seguro contratado, por impedírselo la ley de presupuestos de la Comunidad Autónoma competente.
} 
precedidos por la declaración general contenida en el art. 6.2.1: el punto de partida es la subsistencia del deber de cumplimiento, aunque la prestación hubiere devenido más onerosa. En los Comentarios se insiste en la persistencia de aquel deber, aunque el cumplimiento implique pérdidas, en lugar de los beneficios esperados, o incluso cuando carezca de sentido para la parte obligada. Las reglas sobre hardship, terminología adoptada por razón de su uso habitual en la contratación internacional ${ }^{146}$, representan la excepción a este principio general. La Nota reitera estas ideas en el punto 33.

80. La aplicación de los remedios para la excesiva onerosidad sobrevenida se subordina, en primer término, a una situación de alteración fundamental del equilibrio de las prestaciones. En los ejemplos de los Comentarios se reiteran los adjetivos de "incremento sustancial" de los costes de producción por subidas "dramáticas" en el precio de la materia prima o costes de producción "mucho más" elevados, pero se evita mayor concreción, remitiendo a las circunstancias del caso concreto.

81. Es igualmente preciso que el desequilibrio haya sido provocado por circunstancias sobrevenidas que reúnan, cumulativamente, el carácter de imprevisibles, ajenas al control de la parte perjudicada y sin que esta hubiera asumido el riesgo de tales eventos (art. 6.2.2). Podrá entonces requerir una renegociación (art. 6.2.3 PICC), sin suspender su propia prestación. En defecto de acuerdo en tiempo razonable, cualquiera de las partes podrá acudir a un tribunal que, en caso de apreciar la excesiva onerosidad, y siempre que lo considere razonable, podrá resolver el contrato o adaptarlo con el fin de restablecer su equilibrio.

82. La frontera entre la hardship y una circunstancia impeditiva del cumplimiento, como antes hemos advertido, puede ser difusa, y de ello se hace eco la Nota ${ }^{147}$, advirtiendo que una misma contingencia -por ejemplo, cuando se prohíbe el acceso a la materia prima en el lugar de producción casi exclusivo, siendo muy costosa su adquisición en otro lugar- podría ser considerada como un impedimento para el cumplimiento, y, al mismo tiempo, una alteración fundamental del equilibrio del contrato, por ser una alternativa mucho más onerosa. La Nota añade que, en este caso, "corresponde a la parte afectada por los acontecimientos decidir la vía que ha de seguirse"148.

83. Nuestro TS mantiene, no obstante, la importancia de diferenciar entre una y otra pretensión, en particular cuando el perjudicado por los sucesos sobrevenidos es el deudor de una obligación pecuniaria, en la que no tiene cabida la imposibilidad, pues esta "solamente afecta a las obligaciones de dar cosa determinada o de hacer". Mientras que la doctrina de la rebus sic stantibus, en la que encaja la prestación devenida exorbitante o excesivamente onerosa, "opera con independencia de cuál sea el contenido de la prestación pactada". "Se trata de acciones diversas y, de ahí, la importancia y relevancia que tiene para las partes fijar el objeto del pleito, a fin de que el Tribunal ofrezca respuesta adecuada al mismo". Se advierte, con todo, que en ambos casos se requiere que los sucesos que provocan uno y otro resultado sean imprevisibles; la ausencia de esta característica determinará el rechazo, tanto de la noción de imposibilidad sobrevenida con virtualidad liberatoria, como de la viabilidad de los remedios jurídicos asociados a la rebus ${ }^{149}$.

\footnotetext{
${ }^{146}$ Los Comentarios ya advierten que la terminología es variada, para hacer referencia al mismo fenómeno: Wegfall der Geschäftsgrundlage, imprévision, eccessiva onerosità sopravvenuta, etc.

${ }^{147}$ V. supra, II.1, ap. 21. Y Nota, ap. 50.

${ }^{148}$ Nota, ap. 21, intitulado "Flexibilidad en la elección del remedio".

${ }^{149}$ STS de 19 mayo 2015 (RJ. 3118). En el caso se ejercitaba por la vendedora de un inmueble una acción de cumplimiento. La parte demandada oponía la imposibilidad derivada de la situación de penuria económica provocada por el repentino fallecimiento de su marido, dejándola con exiguos ingresos y tres hijos menores a su cargo. En primera instancia se estimó la demanda, considerando que no concurrían los presupuestos de la rebus; la Audiencia Provincial confirmó, aplicando como ratio decidendi la doctrina sobre la (ausencia de) imposibilidad sobrevenida de la prestación. El TS, aunque advierta, como se ha dicho en el texto, la diferencia entre ambas acciones y achaque a las instancias cierta confusión, advierte que, además de no concurrir imposibilidad sobrevenida por tratarse de obligación pecuniaria, las "contingencias relacionadas con la salud", "con afectación de su solvencia", son previsibles, "según es notorio por máximas de experiencia". Pues aun cuando el accidente sea en sí inevitable, no ocurre lo mismo con su repercusión sobre la solvencia, "como también se colige de máximas de
} 


\section{La situación de hardship en los Principios: aumento de coste de la prestación propia o disminu- ción de valor de la que se recibe}

84. Es importante perfilar el escenario de excesiva onerosidad susceptible de desencadenar los efectos de renegociación o intervención judicial previstos en el art. 6.2.3 PICC. Se identifica con una alteración fundamental del equilibrio contractual por la superveniencia de ciertos eventos, "bien porque el coste de la prestación a cargo de una de las partes se ha incrementado, o porque el valor de la prestación que una parte recibe ha disminuido" (art. 6.2.2, primer inciso).

85. La Nota insiste en este aspecto (n. 35): la modificación fundamental del equilibrio por una causa vinculada a la COVID-19 "debe haber aumentado el coste de la prestación de una de las partes o disminuido el valor de dicha prestación para una de las partes (incluyendo el caso de que la prestación haya perdido totalmente su valor para la parte destinataria) y, en ambos casos, es necesario que el aumento del coste o la disminución del valor puedan ser constatados y determinados objetivamente"; una alteración que además, "solo afectará a las prestaciones no ejecutadas" en contratos de tracto sucesivo. La alteración subjetiva no es relevante.

86. Las medidas adoptadas como consecuencia de la pandemia podrían provocar un incremento de los costes que el deudor ha de afrontar para cumplir con su prestación, debido, por ejemplo, a las restricciones a la exportación de materiales de protección impuestas por las autoridades de un país, que obligan a adquirir aquellos en otro lugar y a un mayor precio; o por la subida en los costes de extracción o producción de la materia prima que el deudor necesita para manufacturar el objeto debido y provocada, por ejemplo, por una restricción obligatoria del número de trabajadores (Nota, n. 36).

87. En cuanto al desequilibrio sobrevenido por razón de la disminución o pérdida del valor de la prestación que se recibe por el acreedor, los ejemplos de la Nota son sin duda iluminadores y recurrentes: el arrendatario de un local dedicado a restaurante se ve obligado a pagar íntegramente la renta estipulada cuando debe limitar o incluso cambiar su actividad (solo puede servir comida para llevar, o debe reducir el aforo) por razón de las medidas impuestas por la autoridad pública. O un club de fútbol debe seguir abonando los elevados salarios convenidos inicialmente, cuando los partidos de fútbol pasan a desarrollarse sin espectadores, privando al club de un alto porcentaje de sus ingresos ${ }^{150}$.

88. Conviene recordar, no obstante, que el desequilibrio por razón de la pérdida de valor de la prestación que se recibe comprende, en los Comentarios al art. 6.2.2, dos supuestos: de un lado, la que deriva de circunstancias generales del mercado y apreciable objetivamente (por ejemplo, en caso de drástica inflación y su repercusión sobre el precio acordado); de otro, la frustración del propósito concreto que justifica la celebración del negocio; el ejemplo es la prohibición de edificar en la finca adquirida para esta finalidad. En este segundo caso, se dice, es necesario que el propósito contractual frustrado hubiere sido conocido (o debido conocer) por ambas partes.

89. El equilibrio alterado es el que media entre prestación y contraprestación en un contrato sinalagmático y, en este sentido, la noción es similar a la utilizada en otras propuestas de Derecho uniforme ${ }^{151}$. La desproporción entre ambas resulta de la comparación actual, en un contexto de mercado muy distinto al presente en el momento de contratar. La carga puede resultar especialmente ruinosa para el deudor enfrentado a la subida vertiginosa y acaso disparatada del coste de su propio cumplimiento,

experiencia", por lo que la parte compradora con precio aplazado "suele concertar un contrato de seguro que cubra el siniestro descrito, a fin de evitar la insolvencia a que se ha hecho mención”. Pero todo ello sin dejar de recordarle a la parte demandante que todavía podría optar por la resolución del contrato, conforme al art. 1124 CC.

${ }^{150}$ La Nota advierte (ap. 37 y nota 22) que, como siempre, apreciar la excesiva onerosidad se sujeta a un atento examen de todas las circunstancias, y en el análisis del ejemplo del club de futbol habría que considerar otros ingresos procedentes de fuentes alternativas.

${ }^{151}$ PECL, art. 6:111. DCFR, art. III.- 1:110. 
mientras que el envilecimiento de la prestación que se recibe, al menos para el deudor/comprador o arrendatario, contará siempre con el techo del precio pactado en el contrato, aunque su importe se considere ahora desproporcionado, debido a la pérdida de valor de lo obtenido a cambio ${ }^{152}$.

90. Los Principios Unidroit, en definitiva, incluyen en la hardship supuestos heterogéneos que abarcan tanto la excesiva desproporción económica entre las recíprocas prestaciones de las partes, derivada de circunstancias objetivas de mercado, como la frustración del concreto propósito para cuya consecución se llegó al contrato; caso este último incluido como un ejemplo de pérdida de valor de la prestación recibida por el accipiens. Acaso por esta razón, entre los requisitos adicionales enunciados en los PICC, nada se diga sobre limitar la noción de hardship a los contratos de tracto sucesivo, aunque en el Comentario se advierta que será el supuesto normal de aplicación. La frustración del propósito concreto común o, al menos, del objetivo esencial de una de las partes, conocido y compartido como base del negocio por la otra, se suscitará con frecuencia, en cambio, en contratos de tracto único.

\section{La doctrina rebus en la jurisprudencia del Tribunal Supremo}

91. La ausencia de una norma que establezca los presupuestos y efectos del desequilibrio contractual provocado por una alteración sobrevenida de las circunstancias nos remite a los requisitos reiterados en una extensa jurisprudencia, que, a pesar de su falta de plasmación legal y a fuer de repetidos, han adquirido una suerte de valor codificado ${ }^{153}$.

Sirva de ejemplo lo manifestado en la STS de 17 noviembre $2000^{154}$, que contiene una ajustada y concisa descripción sobre el régimen jurídico de la rebus, con cita de los hitos jurisprudenciales más relevantes. Sentencia que se trae ahora a colación porque el TS entiende que su propia doctrina "se acomoda, en cierto sentido, al concepto de 'hardship', acogido en los Principios sobre Contratos Comerciales Internacionales (Roma-1995), al declarar que concurre cuando sucesos posteriores, no razonablemente previstos, imponen una excesiva onerosidad". Según esta doctrina, "para que proceda la referida cláusula en los contratos duraderos, según la jurisprudencia reiterada de esta Sala [...] se parte de que, no obstante apoyarse en principios de equidad, su aplicación por los Tribunales ha de hacerse cautelosamente y con moderación y asi sólo procede cuando se cumplen los requisitos que exige la doctrina jurisprudencial, atendiendo a las circunstancias particulares de cada caso, y vienen a consistir en que se produzca alteración extraordinaria de las circunstancias en el momento de cumplir el contrato en relación a las previstas al tiempo de su celebración, tratándose por tanto de circunstancias imprevisibles por completo, y que vienen a actuar aportando una desproporción inusitada y exorbitante, fuera de todo cálculo, que aniquila el necesario equilibrio de las prestaciones, otorgándose a la referida cláusula efectos modificativos del contrato, encaminados a compensar el desequilibrio obligacional instaurado -lo que supone plantear demanda o, en su caso, su petición por vía reconvencional-, pero no autoriza la extinción o resolución de la relación por la alteración sobrevenida de la base negocial, lo que cabría considerar teóricamente si se diera desaparición total de dicha base, determinante de imposibilidad plena en el cumplimiento de las prestaciones".

92. La rebus sic stantibus se utiliza por el TS como síntesis de los requisitos necesarios para apreciar la relevancia del desequilibrio sobrevenido, y como equivalente de otras teorías o fundamentaciones identificadas, en ocasiones, por referencia a su país de origen: excesiva onerosidad sobrevenida (Italia), imprevisión (Francia), base del negocio (Alemania).

${ }^{152}$ De ahí que, como ha sido reiteradamente señalado, habría mayor inclinación a proporcionar alivio al deudor frente a costes disparados y una pérdida en teoría ilimitada que, correlativamente, proporcionan al acreedor una ganancia inesperada, de mantenerse incólume el precio inicialmente acordado. En este sentido, Treitel, G.H., Frustration and Force Majeure, Sweet \& Maxwell Thomson Reuters, London, 2014, p. 273. EIsenBERG, M.A. "Impossibility, Impracticability and Frustration", en Journal of Legal Analysis n ${ }^{\circ}$ 207, 2009, p. 238.

${ }^{153}$ Desde que se formularon en la STS 17 mayo 1957 (RJ 2164).

${ }^{154} R J 9343$ 
93. En casi cien años de jurisprudencia ha sido sin duda excepcional apreciar la concurrencia de esa desproporción "inusitada y exorbitante". Los mayores costes que deba afrontar el deudor para procurar su propia prestación, así como la desproporción sobrevenida entre el valor de lo que recibe y lo que entrega a cambio, o bien se habrá atribuido causalmente a un evento acaecido en su propia esfera de control, o bien se imputará a las vicisitudes del mercado y la evolución de la economía, considerados un riesgo general de la vida que cada parte asume, para mal o para bien ${ }^{155}$.

94. Las hipótesis de frustración del fin o propósito concreto - que en los PICC también constituye un supuesto de hardship como pérdida de valor de la prestación que se recibe- en ocasiones se han resuelto de modo favorable a la parte perjudicada con base en la invocación y admisión de la doctrina rebus. Pero, con mayor frecuencia, y probablemente de modo más ajustado a los instrumentos técnicos de nuestro sistema, se han abordado prescindiendo de -o incluso rechazando- aquella doctrina y acudiendo a los remedios jurídicos asociados a la caída de la causa subjetiva concreta (o motivos causalizados) o a la sobrevenida inutilidad del objeto para satisfacer el interés del acreedor (error vicio ${ }^{156}$, imposibilidad económica, hecho obstativo que de manera definitiva impide la obtención de lo debido en virtud del contrato).

\section{A) La excesiva onerosidad sobrevenida en puertas del Covid-19}

95. El supuesto de hecho de la rebus ha sido el de la "desproporción inusitada entre las recíprocas prestaciones de las partes" 157 ; una desproporción "exorbitante, fuera de todo cálculo que verdaderamente derrumbe el contrato por aniquilamiento del equilibrio de sus prestaciones" 158 . Una "técnica para enmendar el desequilibrio de las prestaciones a lo largo del tiempo en que deban cumplirse" 159 .

96. La STS de 17 enero $2013^{160}$, con el telón de fondo de una grave crisis económica, se mantiene en la misma línea en cuanto a la caracterización del evento que puede desencadenar la aplicación de

${ }^{155}$ Ejemplo de esa admisión cuasi excepcional son dos sentencias en las que las alteraciones de valor se encuentran ligadas a conflictos bélicos o a la crisis subsiguiente. La STS de 18 marzo 1929 (C.L. J.C. 1929, nº 93, pp. 463-471) acude a la interpretación del contrato para decidir que la moneda "marcos" en la que debía hacerse el pago no podía entenderse referido a "marcos papel", con independencia de su valor, sino a moneda "metálica": "Ni en buenos principios de moral contractual ni conforme a estricta justicia es lícito sostener que pueda reputarse legalmente cumplido un contrato por el que estando obligada una de las partes a satisfacer a la otra determinada cantidad, trate de efectuarlo en moneda o signo representativo de ella que por efecto de su depreciación carezca en absoluto de valor...pues ello equivaldría a desnaturalizar por completo la índole de un contrato esencialmente oneroso, que por serlo no permite términos de cumplimiento tales que resulte beneficioso para uno de los contratantes y notoria y totalmente perjudicial para el otro, convirtiéndolo en aleatorio, sin que lo autorice ni el texto ni el sentido de cláusula alguna contractual”.

La famosa STS 13 junio 1944 ( $R J 893$ y 893 bis) en primera sentencia desestima la extinción de la obligación genérica de entregar una cantidad de aceite de orujo, aunque el vendedor alegaba la destrucción de las existencias que tenía preparadas en 1936, habiéndose anticipado el pago. El cumplimiento se exigía, sin embargo, cuando, después de la contienda, el valor del aceite debido se había incrementado extraordinariamente, en relación con el precio originariamente pactado y ya pagado. La segunda sentencia, dictada por casación de la recurrida, modera la prestación reduciendo la cantidad de aceite a entregar. Se procede "con gran cautela y notoria justificación", por la "anormalidad provocada por la guerra". El quebranto "por la desvalorización de la moneda y por aumento del precio del aceite en más de un 50 por 100 del valor de la mercancia (...) debe repartirse entre comprador y vendedor, pero no precisamente por mitad, sino conjugando los múltiples factores que concurren en el caso de autos".

${ }^{156}$ Por ejemplo, la STS de 3 noviembre 2014 (RJ 5273), aprecia error excusable de la promotora cesionaria en contrato de cesión de solar por obra futura, pues los datos erróneos los suministraba la propia Administración.

${ }^{157}$ STS de 12 junio 1956 ( $\left.R J 2485\right)$.

${ }^{158}$ STS de 17 mayo 1957 (RJ 2164).

${ }^{159}$ STS de 1 marzo 2007 (RJ 1618), en la que se añade: "Bajo la indicada forma o bajo fórmulas doctrinales más evolucionadas, como son presuposición, excesiva onerosidad sobrevenida o la base del negocio se refiere fundamentalmente a relaciones de tracto sucesivo, aunque no se descarta en las de tracto único pero de ejecución diferida, pero siempre con cautela y en casos excepcionales, por alteraciones extraordinarias, y circunstancias imprevisibles, sin otro medio para impedir el perjuicio, y con efectos fundamentalmente modificativos para compensar el desequilibrio"

${ }^{160} R J 1819$. Esta sentencia forma parte de un conjunto de resoluciones - de los años 2012 y 2013 , fundamentalmente- que abordan, en esencia, el mismo problema. Una compraventa inmobiliaria, cuyo precio el comprador esperaba financiar mediante 
la rebus: una alteración sobrevenida que "sea tan acusada que aumente extraordinariamente la onerosidad o coste de las prestaciones de una de las partes o bien acabe frustrando el propio fin del contrato". Descripción reiterada en la STS de 9 enero 2019, que subraya la cautela en su aplicación ${ }^{161}$.

97. Las SSTS de 30 junio y 15 octubre $2014^{162}$ marcaron un punto de inflexión, al propugnar "una configuración plenamente normalizada" de la rebus, no restrictiva o excepcional como antes, que obtendría, se dice, su "fundamento último de las propias directrices del orden público económico, particularmente de la regla de la conmutatividad del comercio jurídico y del principio de la buena fe". Se llega incluso a afirmar que la conmutatividad, "más allá de su mera aplicación como criterio interpretativo, art. 1289 CC", "se erige como una regla de la economía contractual que justifica, ab initio, la posibilidad de desarrollo de figuras como la cláusula rebus sic stantibus ". La parte perjudicada, profesional con experiencia en el sector, alegaba en ambos casos la incidencia de la crisis económica sobre la relación contractual y la disminución de los rendimientos esperados, pretendiendo una reducción de su propia deuda, con acogida favorable por el Alto Tribunal.

98. No obstante, y como manifestación de aquella "normalidad de la figura", el Supremo citó en apoyo de sus argumentos los textos de "armonización y actualización en materia de interpretación y eficacia de los contratos", con referencia expresa a los Principios Unidroit, además de a los PECL y a la Propuesta para la Modernización del Derecho de obligaciones y contratos, de la Comisión General de Codificación (art. 1213 PMCC). Y dijo que aquella "configuración normalizada" o "normal aplicación" habría de tener lugar en "el marco establecido de sus presupuestos y requisitos de aplicación que, de por sí, ya garantizan una prudente aplicación de la figura".

99. Es discutible, empero, que el TS fuera en esta ocasión consecuente con el entendimiento de esos "presupuestos y requisitos de aplicación" que resultan de los textos citados y como manifestación de esa normalidad ${ }^{163}$. En sentencias posteriores se hace también referencia a las "propuestas o proyectos de textos internacionales" como los PICC o los PECL, y se alude a su utilización por la jurisprudencia como criterio interpretativo de las normas de Derecho interno. Pero esto no implica abandonar la cautela que deriva de la necesidad de preservar la fuerza vinculante del contrato como regla de la autonomía privada y, de modo correlativo, del análisis sobre la concurrencia o no de sus presupuestos de aplicación, de inevitable valoración concreta y circunstanciada ${ }^{164}$.

100. Las sentencias de 30 junio y 15 octubre de 2014 han provocado acertadas críticas de la doctrina. Amén de las que cabe dirigir a algunos de los argumentos que se esgrimen por el Supremo para

la subrogación en (u obtención de) un préstamo con garantía hipotecaria sobre el propio inmueble. Un cauce habitual en los años anteriores, cegado o muy limitado con el estallido de la burbuja inmobiliaria y la restricción del crédito. El comprador intentaría entonces la resolución del contrato y su propia liberación alegando, bien la imposibilidad de obtener dicha financiación, bien (de manera cumulativa o subsidiaria) la doctrina de la rebus sic stantibus. El TS, sin embargo, solamente estimaría dicha pretensión resolutoria cuando pudiese afirmar el incumplimiento del vendedor, que se habría obligado a proporcionar a favor del comprador consumidor el concreto resultado de la subrogación, como ocurre en las SSTS de 16 enero 2013 (RJ 3254$), 12$ abril 2013 (RJ 3385), 26 abril 2013 (RJ 3268). De no darse esta circunstancia, la ausencia de financiación será considerada, en principio, riesgo del deudor. V. infra, III.3. C).

${ }^{161} R J 5$. El contrato, por lo demás, era una inversión en bonos que la propia sentencia describe como de contenido fuertemente especulativo y aleatorio.

${ }^{162} R J 3526$ y 6129. El ponente de ambas, Excmo. Sr. Orduña Moreno, incorpora las ideas que había desarrollado en ORduña Moreno, F.J./ Martínez Velencoso, L. Ma., La moderna configuración de la cláusula rebus sic stantibus, Cizur Menor (Navarra), 2013, pp. 248 y ss.

${ }^{163}$ Raventós Soler, A./ Luna Yerga, A./ Xiol Bardají, M., "Cuesta abajo y sin frenos. Comentario a la sentencia de la Sala Primera del Tribunal Supremo, de 30 de junio de 2014”, en Revista Aranzadi Doctrinal, núm. 3/2015: al rechazar el TS la excepcionalidad de la figura, frente al principio de vinculación contractual, "parece confundir dos planos: el del normal reconocimiento de la figura y el de la normalidad de su aplicación". Aunque el TS haga referencia a la prudente aplicación de la rebus, "se echa de menos una mayor claridad expositiva".

${ }^{164}$ STS de 9 enero $2019(R J 5)$. 
construir una doctrina general sobre la figura y fundamentar la mentada "normalización" de la rebus ${ }^{165}$, las dudas conciernen, en primer lugar, a si efectivamente concurría la premisa de excesiva onerosidad provocada por la crisis económica en los casos bajo examen ${ }^{166}$. Tampoco parece claro el carácter imprevisible de las circunstancias que mermaron la rentabilidad del contrato para una de las partes y, sobre todo, se echa en falta al menos una mención a los criterios legales de distribución del riesgo presentes en el CC y de los que cabría derivar reglas generales aplicables en el tipo de contrato litigioso. En cuanto a la efectiva incidencia de la crisis y su carácter imprevisible, la parte perjudicada era persona con dilatada experiencia en el sector, con un contrato que, en un caso, era de duración relativamente breve y había entrado ya en el último año pactado (en la STS de 30 junio 2014), mientras que, en el otro, contaba con mecanismos de salida a favor del arrendatario, tras un periodo mínimo de duración obligatoria (transcurridos los diez primeros años de un total de 25, en la STS de 15 octubre 2014), si el contrato dejaba de interesarle ${ }^{167}$. En lo que hace a la naturaleza del contrato y la distribución legal del riesgo, sorprende que ni siquiera se cite el art. $1575 \mathrm{CC}$, que suministra un criterio para la rebaja de la renta en el contrato de arrendamiento, en caso de "pérdida de más de la mitad de los frutos por casos fortuitos extraordinarios e imprevistos", salvo pacto en contrario ${ }^{168}$.

101. La jurisprudencia posterior ha matizado algunas de las afirmaciones de las sentencias de 2014 , con cierta recuperación de los presupuestos en su enunciado jurisprudencial tradicional ${ }^{169}$. Sobre todo, se observa un especial cuidado en analizar y explicitar cuáles son, en el caso litigioso, los criterios de distribución de los riesgos entre las partes en atención a lo que resulte de la ley y de la interpretación del contrato, como premisa y guía necesaria para determinar si los acontecimientos sobrevenidos sustentan o no una pretensión de modificación o de resolución del contrato ${ }^{170}$. La STS de 15 enero $2019^{171}$ lo resume claramente en los siguientes términos: "Debe tenerse en cuenta que, si bien en las sentencias que cita el recurrente se aplicó con gran amplitud la regla 'rebus', con posterioridad por esta sala ha descartado su aplicación cuando, en función de la asignación legal o contractual de los riesgos, fuera improcedente revisar o resolver el contrato".

${ }^{165}$ En relación con el particular entendimiento del TS acerca de la conmutatividad de los contratos como regla de economía contractual y justificación de la rebus, observa Bercovitz Rodríguez-CANo, R., "Comentario a la STS de 30 de junio de 2014", en $C C J C$, n. 97, 2015, pp.345-367, p. 365, que se desliza la cláusula rebus a una función preocupante porque se convertiría en "garante de las expectativas iniciales de las partes" "en el momento de perfeccionarse el contrato". En situaciones de alteraciones de mercado se convertiría en "una red de seguridad para el empresario perjudicado por las mismas". La conmutatividad "no es garantía de un buen precio ni para el vendedor ni para el comprador".

${ }^{166}$ Bercovitz Rodríguez-CANo, ibidem, en relación con el criterio que se deriva del art. $1575 \mathrm{CC}$, y a la vista de las pérdidas de la empresa perjudicada en un contrato de explotación de la publicidad incluida en los autobuses de la Empresa Municipal de Transportes de Valencia, celebrado en mayo de 2006, con una duración de cuatro años, y posteriormente modificado en el año 2007. Fue a principios de 2009 cuando se alegó la sobrevenida onerosidad del canon estipulado por razón de la drástica diminución, se dice, de las inversiones publicitarias y el descenso de facturación de la empresa obligada al pago. La EMT había procedido a la resolución del contrato por impago, pretensión estimada por la Audiencia, con rebaja, no obstante, de la indemnización pretendida, con argumentos sobre la crisis económica, y el hecho de haberse acordado un canon inferior en un nuevo contrato de adjudicación celebrado por la propia EMT, amén de que podría haber mitigado su propio daño. El TS, en cambio, entendió que procedía la pretensión de modificación del canon estipulado.

${ }^{167}$ PARra LuCÁn, Ma . A., "Riesgo imprevisible y modificación de los contratos" en InDret, 4/2015, pp. 1-54, p. 23.

${ }^{168}$ Carrasco Perera, A., "Reivindicación y defensa de la vieja doctrina rebus sic stantibus. Comentario a la STS de 15 de octubre de 2014", en CCJC, n.98, 2015, pp. 175-206. Del art. 1575 CC deduce, además, varias reglas: "Hay un elenco de contingencias desequilibradoras sobrevenidas que siempre han de reputarse ordinarias, en la esfera de riesgo del deudor"; "hay una frontera por debajo de la cual el riesgo extraordinario no puede ser externalizado por el deudor en el acreedor: "menos de la mitad de los frutos'“; y "por hundimiento del equilibrio contractual debido a la realización del riesgo (insólito) del negocio, no tiene el arrendatario del art. 1575 CC derecho a una rebaja de la renta". El precepto se trae a colación, sin embargo, en la muy correcta STS de 15 enero 2019 ( $R J 146$ ): el asunto aquí también es un contrato de arrendamiento y las circunstancias son similares. La disminución de los rendimientos en la explotación del hotel no puede desplazarse sobre la otra parte, porque este riesgo, "al proceder del deterioro de la situación económica y las variaciones del mercado, debe ser considerado como propio de la actividad empresarial de la arrendataria, una empresa dedicada a la gestión hotelera".

${ }^{169}$ STS de 9 enero 2019 (RJ 5).

${ }^{170}$ SSTS de 20 julio 2017 (RJ 3653), 15 enero 2019 ( $\left.R J 146\right), 5$ abril 2019 (RJ 1360); SSTS 452/2019, de 18 julio (RJ 3010) y 455/2019, de 18 julio (RJ 3599), 6 marzo 2020 (RJ 879). Sobre los criterios de asignación de riesgos que se reflejan en estas sentencias, v. infra, III.5 C) y D).

${ }^{171}$ STS de 15 enero 2019 (RJ 146). 
102. La rebus, ciertamente, no puede ser considerada un elemento extraño al sistema, entendida como técnica o argumento de decisión en casos de alteración extraordinaria de las circunstancias, goce o no de sanción legal expresa. Su tradicional aplicación excepcional o cautelosa surgió probablemente como respuesta a una desmedida tendencia a propugnar su aplicación en contratos entre empresarios, a modo de válvula de escape de una de las partes para evitar la incidencia negativa en su posición contractual de circunstancias generales del mercado relevante, o provocada por la evolución de la economía en general. Circunstancias o evolución que, de modo correlativo, mejoraban la posición de la otra parte cubierta - precisamente mediante el contrato y como una de sus funciones primordiales- frente a ulteriores oscilaciones de valor de las respectivas prestaciones. El punto de partida es la vinculación del deudor a lo pactado, aunque la prestación haya devenido más onerosa. De ahí que, como expresa la jurisprudencia, deberán explicarse "las concretas razones por las que en el caso debe desplazarse a la otra parte" la disminución de los rendimientos de la parte demandante ${ }^{172}$. Los razonamientos empleados para justificar esta cautela, como veremos más adelante, no difieren en esencia de los requisitos exigidos en los Principios Unidroit para que una de las partes invoque en su favor la hardship.

103. Hay, además, otro elemento relevante que la jurisprudencia toma en consideración al enjuiciar la respectiva posición de las partes, aunque no suele explicitarlo cuando enuncia los requisitos de la rebus. Para calibrar el perjuicio alegado por una de ellas, habrán de ser también valoradas las ayudas públicas o subvenciones recibidas, $\mathrm{o}$, en su caso, las ventajas obtenidas, precisamente a raíz de los mismos eventos causantes del desequilibrio ${ }^{173}$.

\section{B) La frustración del fin del contrato}

104. Como es bien sabido, uno de los casos recurrentes en la jurisprudencia se relaciona con los avatares de la legislación urbanística y su incidencia sobre la rentabilidad esperada por el comprador o por el cesionario de solar por obra futura. También comparece en contratos de arrendamiento, cuando eventos externos al propio contrato (por ejemplo, la no obtención de las licencias administrativas precisas, o del permiso de la comunidad de vecinos) impiden de manera definitiva desarrollar en el local arrendado la actividad o el negocio propio del arrendatario.

105. El problema ahora suele enfocarse en torno a la determinación del contenido de la prestación debida, empezando por averiguar si el acuerdo incorporó a cargo del deudor la efectiva satisfacción de aquel específico interés; asunto que a su vez depende del tipo y naturaleza del contrato, de la condición de profesionales de los contratantes y de la correcta interpretación de la voluntad común ${ }^{174}$. Cuando la respuesta sea afirmativa, la falta de obtención de aquella finalidad se sitúa generalmente en el terreno del incumplimiento o de la imposibilidad con trascendencia resolutoria. Si se aprecia, en cambio, que el riesgo estaba asignado al accipiens, tampoco servirá la doctrina rebus para resolver el contrato o rebajar el precio por un supuesto envilecimiento de la prestación cuando la posterior crisis económica provoca la caída o ralentización de, por ejemplo, la expectativa de desarrollo urbanístico de la zona ${ }^{175}$.

${ }^{172}$ STS de 15 enero 2019 ( $R J$ 146). En el caso, la disminución de los rendimientos de la explotación de un hotel, riesgo que, según el Supremo, "al proceder del deterioro de la situación económica y a las variaciones del mercado, debe ser considerado como propio de la actividad empresarial de la arrendataria, una empresa dedicada a la gestión hotelera".

${ }^{173}$ V. la doctrina y la jurisprudencia que se cita en GonZÁlez PACANOwSKA, Isabel, "Alteración sobrevenida de circunstancias en los contratos sinalagmáticos: de la rebus sic stantibus a la alteración extraordinaria de circunstancias", en González Pacanowska, Isabel, y García Pérez, Carmen L. (coords.), Estudios sobre incumplimiento y resolución, ed. Thomson Reuters Aranzadi, Cizur Menor (Navarra), 2015, pp. 188 y ss.

${ }^{174}$ STS de 22 julio 2013 (RJ 5005).

${ }^{175}$ La STS de 24 febrero 2015 ( $R J$ 1409), aunque reitere la doctrina de las sentencias del mismo ponente sobre la normalización en la aplicación de la doctrina rebus, decide que, en atención a la "asignación contractual del riesgo", pese a que la parte vendedora era conocedora de la finalidad urbanizadora que impulsaba la celebración del contrato, no podía estimarse que la "posible fluctuación posterior del valor de mercado, ya al alza o a la baja, que podía afectar a las fincas objeto de la venta, quedase excluida del riesgo normal o inherente que debía asumir la parte compradora, conforme a la naturaleza y el contenido 
106. Ahora bien, generalmente, cuando no se proporciona a una de las partes lo que tenía legítimo derecho a esperar en virtud del contrato, se abre el abanico de remedios propios del incumplimiento. La salida natural en este tipo de situaciones es la resolución del contrato. Dicha pretensión será estimada, con independencia de que aquella frustración sea o no imputable, siempre que se haya establecido como premisa que efectivamente incumbía al deudor garantizar la utilidad o la finalidad perdidas. Los tribunales aluden aquí con frecuencia a la desaparición de la base del negocio o de la causa concreta del mismo, habiéndose incluso considerado "extravagante" el recurso a la rebus y a su efecto característico de adaptación o modificación del contrato, cuando la prestación recibida no responda en absoluto o deje luego de servir (en contrato de tracto sucesivo) a la finalidad para cuya consecución se concertó el contrato ${ }^{176}$.

\section{C) Crisis y dificultades económicas del deudor}

107. Aunque sobre esto no se pronuncian los PICC, ni se alude a ello en la Nota, la crisis económica subsiguiente a la pandemia podrá plantear, de nuevo, la aplicación de la doctrina sobre la excesiva onerosidad a situaciones de sobrevenida dificultad económica del deudor. La insolvencia del deudor en el contexto COVID deberá ser resuelta, en primer término, por las normas sobre el concurso de acreedores $^{177}$ y mediante la aplicación de las medidas legislativas específicas orientadas a personas que se encuentren en la situación de vulnerabilidad que la propia norma describe ${ }^{178}$. Nótese que el devenir de los acontecimientos puede haber convertido el cumplimiento de lo debido en una carga insoportable para un deudor que, por circunstancias sobrevenidas, afronta graves problemas de liquidez o ha visto frustradas sus expectativas de financiación. Lo cual no significa, como regla general, un correlativo desequilibrio fundamental y objetivo entre las prestaciones, en el sentido antes descrito.

108. Respecto del problema de ausencia de financiación, los tribunales han sido, en general, reacios a estimar la pretensión del deudor profesional de apartarse del contrato alegando que la subvención o financiación que habría de proporcionar un tercero era un presupuesto básico para la decisión de contratar, o que su ausencia ha mermado significativamente la rentabilidad esperada ${ }^{179}$. Un asunto recurrente en los últimos años afecta al comprador de un inmueble, que confiaba en obtener la subrogación en el préstamo hipotecario otorgado al vendedor o en su nueva contratación; esperanza frustrada por la imprevista restricción del crédito a raíz de la crisis. Descartado el argumento de la imposibilidad sobrevenida en deuda pecuniaria, el TS apuntó en este terreno la posible invocación de la rebus, en atención a diversos condicionantes: el destino del inmueble, la asignación contractual del riesgo, la situación económica del comprador, el grado real de imposibilidad de financiación y sus causas, o, en fin, las posibilidades de negociación de las condiciones de pago con el vendedor con objeto de mantener el contrato ${ }^{180}$.

negocial del contrato celebrado". Lo que se deduce de la interpretación del contrato, así como de la comparación con otros supuestos en los que un concreto desarrollo urbanístico se integra como condición o elemento esencial del acuerdo o como factor determinante para el precio. La crisis por sí sola no es suficiente para justificar la rebus y, se añade, no se ha acreditado una excesiva onerosidad en cuanto al precio o su financiación, ni un envilecimiento del valor de la prestación: el desarrollo urbanístico es viable y, "como riesgo empresarial", dependerá del "contexto económico".

${ }^{176}$ Sobre esta jurisprudencia, tanto en contratos de arrendamiento de cosas, cuando la cosa arrendada no puede utilizarse para la finalidad pactada (se trate de imposibilidad inicial o de imposibilidad sobrevenida, incluso económica) y aunque sea por causas ajenas al arrendador, como en contratos de compraventa, cuando se frustra lo que en el caso se describe como el motivo causalizado, integrado por la voluntad común como base del contrato, v. la doctrina y la jurisprudencia que se cita en GonZÁLEZ PACANOWSKa, “Alteración...”, cit. pp. 171, 194 y ss.

${ }^{177}$ En relación con la solicitud de declaración de concurso, el art. 6 de la Ley 3/2020, de 18 de septiembre, de medidas procesales y organizativas para hacer frente al COVID 19 en el ámbito de la Administración de Justicia (modificado por RDLey 34/2020, de 17 de noviembre, Disp. Adic. 10a, apartado 3) traslada el deber de solicitarlo hasta el 14 de marzo de 2021.

${ }^{178}$ V., sobre las medidas en beneficio de sujetos vulnerables en distintos ámbitos, supra, I.2, aps. 7 y ss., así como las modificaciones del RDLey 11/2020, de 31 de marzo, introducidas por RDLey 37/2020, de 22 de diciembre, de medidas urgentes para hacer frente a las situaciones de vulnerabilidad social y económica en el ámbito de la vivienda.

${ }^{179}$ SSTS de 4 julio 1996 ( $R J$ 7032), 20 mayo 1997 ( $R J$ 3890), 23 junio 1997 ( $R J 5201$ ), 14 junio 1999 ( $R J 4105$ ), 17 noviembre 2000 (RJ 9343) y18 enero $2012(R J 2013,1604)$.

${ }^{180}$ STS de Pleno de 17 enero 2013 (RJ 1819). 
109. Pero el TS no ha llegado a aplicar la cláusula para estimar la resolución instada por el comprador. El triunfo de esta pretensión ha ido siempre ligada al incumplimiento del vendedor, cuando de la interpretación del contrato resultase su obligación de garantizar el resultado de la financiación. En los casos de dificultades de financiación "no cabe la exoneración del deudor con invocación de la doctrina de la cláusula rebus", concluye en definitiva la STS de 13 julio 2017, con exhaustiva exposición de la jurisprudencia anterior ${ }^{181}$.

\section{Las circunstancias sobrevenidas y su incidencia causal sobre la excesiva onerosidad}

110. La Nota, en aras de simplificar la tarea, reúne todas las circunstancias en dos grupos: la pandemia en sí misma, y, "lo que es más importante por su efecto sobre la ejecución del contrato, las medidas adoptadas para contenerla" (ap. 12). Mas, como enseguida advierte, "todo es una cuestión de grados de causalidad". La pandemia en sí es causa de impedimentos y cambios de circunstancias ${ }^{182}$, muchos de los cuales, a su vez, serán creadas por las medidas de contención; medidas que, con distinta intensidad, pueden repercutir en el incremento del coste de la prestación propia o la pérdida de valor de la que se recibe. Muchos de los problemas que afecten a la ejecución del contrato, añade la Nota, "estarán causados por una crisis económica derivada, primero de la pandemia, y, posteriormente, de las medidas aplicadas para contenerla".

111. La experiencia de la crisis económica de 2008 nos permite distinguir en la jurisprudencia española, grosso modo, dos tipos de situaciones. La primera es la propia de la rebus: el desequilibrio fundamental entre las recíprocas prestaciones, en cualquiera de los dos sentidos ya analizados, que podría desencadenarse a raíz de las causas antes enunciadas. La segunda, la disminución de los ingresos del deudor, generalmente de obligación pecuniaria, por razón de la crisis económica, en particular por el cierre de la vía de la financiación o de la subvención con la que contaba, en el momento de la celebración del contrato. Como antes hemos visto, el TS anunció la posible aplicación de la doctrina rebus para aliviar la falta de liquidez del deudor no profesional, pero solamente llegó a estimar la pretensión resolutoria allí donde pudiera apreciarse que el vendedor había asumido el riesgo de la sobrevenida ausencia de financiación.

112. Otra de las enseñanzas de la reciente jurisprudencia es que una crisis económica, aunque sea hecho notorio y generalizado, no es, por sí sola, justificante de la rebus. Incluso cuando se trate de una crisis de carácter extraordinario y prolongado, no se ha postulado por ello una aplicación generalizada ni automática; será en todo caso necesario "que se contraste su incidencia causal o real en el marco de la relación contractual de que se trate" ${ }^{\prime 183}$.

\section{Los requisitos adicionales para invocar la excesiva onerosidad en los Principios y en la jurispru- dencia del Tribunal Supremo. Aplicación en tiempos de crisis COVID}

113. El art. 6.2.2 de los Principios establece cuatro requisitos adicionales que, hasta cierto punto, se implican recíprocamente y, en realidad, no difieren de los que enuncia el TS, con terminología más ajustada a nuestro sistema.

\footnotetext{
${ }^{181}$ Sobre esta jurisprudencia y con mayor desarrollo, v. la doctrina y la jurisprudencia que se cita en GonZÁLEZ PACANOWSKA, “Alteración...", cit., pp. 203 y ss. V., además, SSTS de 19 mayo 2015 (RJ 3118) y 30 diciembre 2015 (RJ 5874). De especial interés es la STS de 13 julio 2017 ( $R J$ 3962), que recoge toda la jurisprudencia anterior, y explica que las partes pueden atribuir el riesgo de la falta de financiación al vendedor, y que así ocurre cuando este asume contractualmente el compromiso de procurar al comprador la financiación.

${ }_{182}$ Por ejemplo, el inevitable descenso en la demanda de determinados bienes y servicios por razón de la enfermedad misma o del confinamiento voluntario, por el temor a contraerla. V. CARrasco Perera, “Alquileres...”, cit., p. 7.

${ }^{183}$ Entre las más recientes, SSTS de 5 abril 2019 (RJ 1360), 11 diciembre 2014 (RJ 6374), 24 febrero 2015 (RJ 1409) y 30 junio 2014 (RJ 3526).
} 


\section{A) Circunstancias sobrevenidas a la celebración del contrato}

114. El art. 6.2.2 (a) PICC exige, para empezar, que los eventos causantes de la excesiva onerosidad sobrevengan o lleguen a ser conocidos por la parte perjudicada después de la celebración del contrato. En el Comentario se relaciona esto con lo dicho a continuación en el art. 6.2.2 (b): que "los eventos no pudieron ser razonablemente tenidos en cuenta por la parte perjudicada en el momento de celebrarse el contrato". Si habían ya tenido lugar y eran conocidos, no podría concurrir la falta de previsibilidad.

115. La Nota incide, como ya hemos expuesto, en los factores de tiempo y lugar de la celebración del contrato ${ }^{184}$. En lo que hace a poder alegar la hardship, "las medidas de confinamiento que causan la excesiva onerosidad deben, ante todo, haber tenido lugar o haber sido conocidas por la parte perjudicada después de la celebración del contrato". No se descarta que, en función de las circunstancias del caso, pueda merecer un análisis más detenido fijar el momento de "superveniencia" del evento, para dar cumplimiento a este requisito. A efectos de considerar relevante, por ejemplo, una diferencia entre la adopción de las medidas de confinamiento subsiguientes a la pandemia y su efectivo conocimiento por la parte perjudicada. Diferencia que, en principio, no se tomará en consideración, por tratarse de medidas legales o, en todo caso, de carácter notorio. Aunque, se añade, podría ser más difícil de evaluar respecto de medidas adoptadas en el extranjero, con incidencia en el contrato celebrado ${ }^{185}$.

116. Para el TS ha sido igualmente una constante referir la rebus a una "alteración extraordinaria de las circunstancias en el momento de cumplir el contrato en relación con las concurrentes al tiempo de su celebración" ${ }^{\prime 186}$.

En el caso de la COVID, no obstante, el goteo legislativo de los últimos meses, con sucesivas ampliaciones o reformas de normas recién promulgadas, podría provocar incertidumbre sobre la anterioridad o no del evento de que se trate, y cuya incidencia se invoque, respecto de la fecha de celebración del contrato. Como antes hemos señalado, no deberá haber contratos de cierta complejidad que dejen de tener en cuenta la incidencia de las medidas ya adoptadas y la incertidumbre sobre el ulterior desenvolvimiento de la pandemia y sus consecuencias ${ }^{187}$. Probablemente, sea esa misma inseguridad la que podría rebajar esta exigencia temporal, si se relaciona con la imprevisibilidad ${ }^{188}$.

\section{B) Eventos que no pudieron ser razonablemente tenidos en cuenta por la parte perjudicada en el momento de celebrarse el contrato y que escapan a su control}

117. El art. 6.2.2 exige que los eventos sobrevenidos (b) "no pudieron ser razonablemente tenidos en cuenta por la parte perjudicada en el momento de celebrarse el contrato" y que (c) escapan a su control.

118. Empezando por lo dicho en el art. 6.2.2 (c), la Nota (ap. 40) indica que, como es obvio, este requisito se cumplirá: tanto la pandemia como las medidas de contención, obligatorias e impuestas por el

\footnotetext{
${ }^{184}$ Supra, II. 4. C).

${ }^{185}$ Nota, cit., ap. 38.

${ }^{186}$ Sobre hechos ya conocidos en el momento del contrato (en el caso, la posterior construcción de una autopista), v. STS de 17 mayo 1986 (RJ 2725). Como ejemplo más reciente, STS de 22 enero 2019 (RJ 159). También en el art. 1213 PMCC. El desconocimiento de la parte perjudicada tendría su sede en los vicios de la voluntad o, acaso, en el error sobre la causa (art. 1301 CC). Cfr. Salvador Coderch, P., "Alteración de circunstancias en el art. 1213 de la Propuesta de Modernización del Código Civil en materia de obligaciones y contratos", en InDret, n. 4, 2009, pp. 1-60, p. 25.

${ }^{187}$ V. supra, II.4 C).

${ }^{188}$ En el sentido expresado por SALVAdor CODERCh, op. cit., p. 26, sobre el elemento temporal en el art. 1213 de la PMCC, y sobre la modificación de circunstancias originada por causa ya presente en el momento de celebración del contrato: "El cambio latente puede concurrir en el momento de la celebración del contrato y, en tal caso, habrá que estar a la nota de la imprevisibilidad, pues si la alteración, por más que latente en el momento de la celebración, era entonces imprevisible y solo ex post se revela como relevante, la latencia misma no obsta a la aplicabilidad de la regla del art. 1213" PMCC.
} 
Estados, estarán fuera del control de las partes contractuales. Sobre este punto nos remitimos a lo dicho en relación con los sucesos extraordinarios que nos ocupan, ajenos a la esfera de control de las partes, sin perjuicio de que cada una habrá de adoptar las medidas procedentes para posibilitar el cumplimiento. Precisamente, la adopción de estas medidas puede ser el detonante del desorbitado desequilibrio ${ }^{189}$.

119. En cuanto a la imprevisibilidad del cambio, nos remitimos igualmente a lo expuesto en relación con la fuerza mayor, como hace la Nota (ap. 39), reiterando aquí la relatividad del propio concepto ${ }^{190}$, así como los factores que, en la presente crisis, pueden ser relevantes para apreciar su concurrencia $^{191}$. Como bien dice la Nota (ap. 39), la solución "dependerá en último término de las circunstancias del caso", máxime por "el hecho de que las circunstancias sean eventualmente susceptibles de cambiar progresivamente"192. Cabe advertir, no obstante, y con proyección más específica sobre la rebus, distintas perspectivas en la jurisprudencia, a la hora de deslindar el requisito de la imprevisibilidad y el carácter extraordinario de la alteración.

120. En primer lugar, se alude a la falta de imprevisibilidad con el fin de descartar el cobijo en la rebus de eventos imputables al deudor o pertenecientes a su esfera de control; especialmente cuando se pretende la aplicación de esta doctrina para justificar y eludir las consecuencias del previo incumplimiento propio ${ }^{193}$.

121. En muchas ocasiones, lo "radicalmente imprevisible" se solapa con el carácter extraordinario del evento. Se sitúa en el momento de celebración del contrato y se relaciona con lo que entonces, en el curso normal o habitual de los acontecimientos en el contexto de que se trate, era de probable ocurrencia o razonablemente previsible ${ }^{194}$. Desde esta segunda perspectiva, ha sido una constante hacer hincapié en la condición de profesional o experto en el sector, especialmente para rechazar el carácter imprevisible (o extraordinario) de las alteraciones derivadas de las crisis o transformaciones económicas del mercado, generalmente calificadas como eventos comprendidos dentro del alea normal del contrato ${ }^{195}$. De ahí también que la trascendencia de la rebus sea más probable en contratos de larga duración y de tracto sucesivo, pero "no en un supuesto de contrato de corta duración, en el que difícilmente puede acaecer algo extraordinario que afecte a la base del contrato y no quede amparado dentro del riesgo propio de ese contrato" 196.

\footnotetext{
${ }^{189}$ Supra, apartados 38 y 39, y II.4 B).

${ }^{190}$ Supra, II.3, en especial apartados 38 y ss. En relación con la rebus, v. CARrasco Perera, Derecho de contratos, cit. p. 984: “Aunque la jurisprudencia utiliza la fórmula "circunstancias radicalmente imprevisibles", este último superlativo no añade sustancialmente nada nuevo. Basta que se haya dado la alteración [extraordinaria] y la desproporción [exorbitante entre las prestaciones]...y que las circunstancias nuevas no fueran razonablemente previsibles conforme al estándar de previsibilidad que sea exigible a tenor de la naturaleza del contrato (art. $1283 \mathrm{CC}$ ). No hay espacio jurídico entre lo no razonablemente previsible y lo radicalmente imprevisible".

${ }^{191}$ Supra, II. 3 C).

${ }^{192}$ En el Comentario se tiene en cuenta que el cambio puede ser gradual y, en principio, no habría lugar a invocar la hardship si ya se hubiere iniciado al tiempo de celebración del contrato, aunque desemboque en excesiva onerosidad. La valoración sería distinta si el cambio se acelerase de forma dramática e inesperada después de la celebración del contrato. Algo similar podría predicarse sobre el futuro próximo, dada la inseguridad de la evolución y los vaivenes de su incidencia sobre el mercado y los hábitos de consumo.

${ }^{193}$ Por ejemplo, entre otras, SSTS de 17 mayo 1957 (RJ 2164), 21 noviembre 1988 (RJ 2228), 16 octubre 1989 (RJ 6927), 23 abril 1991 (RJ 3923), 29 enero 1996 (RJ 737), 15 noviembre 2000 (RJ 9214: de admitirse la rebus a favor del comprador que había incumplido su obligación de pagar el precio "sería de mejor condición la incumplidora, frente a la que, por haber cumplido, no podría acudir a dicha cláusula”), 27 mayo 2002 ( $R J 4573$ ) y 11 diciembre 2014 ( $R J 6374$ ).

${ }^{194}$ Según la STS de 30 junio 2014 (RJ 3526) la nota de imprevisibilidad "no debe apreciarse respecto de una abstracta posibilidad de la producción de la alteración o circunstancia determinante del cambio, considerada en sí misma, sino en el contexto económico y social en el que incide".

${ }^{195}$ Entre otras, SSTS de 4 junio 1902 (C.L.J.C. 1902, no 158, pp. 900-907), 9 mayo 1983 (RJ 2678), 24 junio 1984 (RJ 3488), 25 enero 2007 (RJ 592), 27 abril 2012 ( $R J 4714)$. Entre las más recientes, y referidas específicamente a la crisis de 2008, SSTS de 5 abril 2019 (RJ 1360), 11 diciembre 2014 (RJ 6374), 24 febrero 2015 ( $R J 1409$ ) y 30 junio 2014 (RJ 3526).

${ }^{196}$ STS de 6 marzo 2020 (RJ 879): las entidades RTVG y TVG cedieron a la demandante la exclusiva de gestión, promoción y venta de espacios publicitarios para su emisión en radio y tv, y esta, a cambio de una comisión porcentual de los ingresos por
} 
122. En tercer lugar, y en relación con la idea del alea propio de la naturaleza del contrato, se subraya en contratos calificados como de "alto contenido especulativo" que lo imprevisible "no acontece cuando la incertidumbre constituye la base determinante de la regulación contractual" "197. No pueden los inversores "aceptar los beneficios de la especulación y repercutir a la vendedora las pérdidas que se pudieran presentar, porque es contrario a la buena fe, art. 1258 CC, y viola el art. 1105 CC"'198. La jurisprudencia de los últimos años, en esta línea, tiende a subrayar la conexión entre la imprevisibilidad y la asignación legal o contractual de los riesgos ${ }^{199}$. Aspecto este último al que nos referimos en el siguiente apartado, siguiendo el orden en el que aparece este requisito en el art. 6.2.2 de los PICC.

\section{C) La asunción del riesgo por la parte perjudicada}

123. El art. 6.2 .2 (d) exige, por último, que "el riesgo de tales eventos no fue asumido por la parte perjudicada". En el Comentario se refiere esta previsión a la asunción voluntaria de riesgo por la parte perjudicada, ya sea en virtud de una cláusula $a d$ hoc, ya sea por la naturaleza del contrato. La importancia de este último elemento ha sido reiteradamente destacada en la doctrina: "la asignación del riesgo del cambio de circunstancias es el punto crucial de toda doctrina sobre revisabilidad de los contratos" ${ }^{200}$. Más aún, se ha dicho que lo realmente importante en esta materia no es el modo en el que se pueda enunciar (o no) la regla rebus, sino formular las subreglas de distribución del riesgo ${ }^{201}$.

124. La jurisprudencia ofrece múltiples ejemplos en los que fracasa la pretensión de modificación del contrato con base en la rebus cuando se aprecie que las eventuales variaciones futuras susceptibles de alterar el equilibrio inicial habían sido contempladas por las partes y, por ende, el riesgo había quedado asignado. No nos referimos ahora solo a una cláusula expresa ad hoc que contemple un evento específico o determinadas alteraciones en particular (sobre la que volvemos más adelante), sino a aquellas otras de las que resulta la previsibilidad del efecto negativo y su asignación al perjudicado, atendiendo al conjunto de las estipulaciones y al reparto de riesgos y beneficios ${ }^{202}$. La conexión entre "interpretación del contrato y la doctrina de la rebus sic stantibus es muy estrecha, porque de lo que se trata es de determinar si, en función de la naturaleza del contrato y de lo acordado por las partes, resulta ya una distribución de riesgos a la que deba estarse"203.

125. El TS, de algún modo, ya señaló esa prevalencia de la distribución del riesgo que resulte de las cláusulas contractuales en la STS de 6 junio $1959^{204}$, al añadir a los requisitos tradicionales que "se

publicidad contratados por su mediación, garantizaba un mínimo anual de ingresos fijos. El contrato tenía una duración inicial de dos años, con prórroga máxima de otros dos. En el primer año de la prórroga la demandante pretendía evitar el canon mínimo fijado, alegando una disminución de la inversión publicitaria, lo que se deniega por el Supremo.

${ }^{197}$ SSTS de 29 octubre 2013 (RJ 8053) y 27 noviembre 2013 (RJ 7874).

${ }^{198}$ STS de 20 julio 2017 (RJ 3653): el demandante era persona experta y "la expectativa de elevadas ganancias del inversor, se compensaba con la posibilidad de sufrir un severo quebranto económico". En asuntos similares, y reiterando la doctrina de las anteriores, STS de 9 enero 2019 (RJ 5).

${ }^{199}$ Cfr. Carrasco Perera, Derecho de Contratos, cit., p. 974: "Como ocurre con el caso fortuito en el art. 1105 CC, la contingencia que dispara la aplicación de la regla rebus ha de ser razonablemente imprevisible para el deudor al tiempo de contratar. Pues un riesgo previsible es un riesgo ya asignado por el contrato a una de las partes".

${ }^{200}$ Salvador Coderch, op.cit. p. 35.

${ }^{201}$ Carrasco Perera, Derecho de Contratos, cit., pp. 987 y 1010.

${ }^{202}$ V., entre otras, SSTS de 15 enero 1910 (C.L.J.C. 1910, n ${ }^{\circ} 12$, pp. 57-70), 14 diciembre 1940 (RJ 1135) 31 octubre 1963 ( $R J$ 4264: la rebus, se dice, no es un remedio para la imprevisión de los contratantes), 23 abril 2012 (RJ 5913), 27 abril 2012 $(R J 4714)$ y 22 abril $2014(R J 2345)$.

${ }^{203}$ STS de 18 julio 2019 ( $R J 3599$ ). Es discutible, con todo, que la cláusula de alteración del precio permita entender también asumido el riesgo de una moratoria de un año impuesta por la ley, en un complejo contrato de transmisión de derechos de explotación de energía generada en huertos solares, afectado en su desarrollo por los cambios legislativos habidos en el país de venta de la energía (Francia).

${ }^{204}$ RJ 3026. El contrato era de arrendamiento de larga duración con opción de compra, celebrado en 1921. La opción se ejercita en 1951. El TS admite la alteración extraordinaria de las circunstancias e incluso la desproporción exorbitante, pero 
careciese de otro medio para remediar el perjuicio". Aspecto en el que incide la jurisprudencia reciente: "la adjetivación de subsidiaria hace referencia, más bien, a que su función no resulte ya cumplida por la expresa previsión de las cláusulas de revisión o de estabilización de precios "205.

126. La STS de 15 enero $2019^{206}$ referida a un contrato de arrendamiento de hotel, tiene en cuenta, en particular, dos estipulaciones de frecuente aparición en la jurisprudencia en contratos de arrendamiento de bienes productivos (arrendamiento de minas o canteras, por ejemplo). Dichas cláusulas son, de un lado, la fijación de una renta mínima (además de una proporción variable, en función de la ocupación) y, de otro, una facultad de libre desistimiento, una vez transcurrido algo más de la mitad de la duración del contrato (con pena razonable). Ambas demuestran, según el Supremo, no solo que el riesgo de disminución de ingresos quedaba a cargo de la arrendataria, sino que tenía un mecanismo de salida para amortiguar el riesgo si el negocio no le resultaba económicamente rentable en las condiciones pactadas ${ }^{207}$. En cuanto a la distribución legal de los riesgos, la STS explicita aquí los criterios sobre rebaja de la renta que acaso cabría generalizar, deducidos del art. 1575 CC: que el arrendamiento sea de bienes productivos, que la pérdida de ingresos no derive de riesgos del propio negocio, que la pérdida se origine por casos fortuitos extraordinarios e imprevistos y, por último, que la pérdida de frutos sea de más de la mitad.

127. La referencia a la naturaleza del contrato, además de lo ya dicho, tiene un claro exponente en la STS de 18 julio 2019208: la rebus no consiente la exoneración de los fiadores, aunque la deuda afianzada se hubiere visto afectada por cambios legislativos. El riesgo de que el deudor no pueda pagar es " $u n$ riesgo típico del fiador" y corría de su cuenta; se recuerda ahora, como ya se hizo para los contratos con alta dosis de aleatoriedad aceptada, que no puede hablarse de alteración imprevisible "cuando la misma se encuentra dentro de los riesgos normales del contrato", ni aun cuando los fiadores aleguen que no habrían consentido la garantía en las actuales circunstancias ${ }^{209}$.

\section{D) Cláusulas específicas sobre asignación de riesgos}

128. En cuanto a las cláusulas contractuales $a d$ hoc y su inserción en los contratos que se celebren a partir de la crisis, se reiteran aquí las consideraciones ya realizadas respecto a la fuerza mayor ${ }^{210}$. A propósito de la hardship, la Nota (ap. 41) subraya, por lo demás, que "siendo la excesiva onerosidad una injerencia cualificada y excepcional en el principio de distribución de riesgos en el cumplimiento del contrato", se puede haber excluido su aplicación mediante la asunción del riesgo del cambio de circunstancias de que se trate, "habitualmente de forma expresa, pero también eventualmente de manera implícita, lo que se constataría mediante la interpretación del contrato a la luz de todas las circunstancias". También en los tiempos del COVID.

el contrato contenía una cláusula de estabilización por referencia a moneda extranjera, habiéndose reservado el vendedor la facultad de elegir la moneda más fuerte. El contrato había sufrido varias modificaciones de mutuo acuerdo con subidas de renta, y el incremento de valor se debía también a la inversión realizada por los arrendatarios.

${ }^{205}$ STS de 30 junio 2014 (RJ 3526).

${ }^{206} R J$ 146. V. MiLÀ RAfel, R., "Cláusula "rebus sic stantibus" y contrato de arrendamiento: el riesgo de disminución de la rentabilidad del negocio debe ser considerado propio de la arrendataria", en CCJC, n. 112, 2020.

${ }^{207}$ Una de las críticas de CARrasco Perera ("Reivindicación y defensa..." cit.), a la STS de 15 octubre 2014 es que se rebaje la renta con base en la rebus cuando por la cláusula de desistimiento, "el arrendatario podía marcharse" "con distintos costes compensatorios en favor del arrendador" y las "penas no eran excesivas". Y a partir de ahí enuncia la siguiente regla "Si el deudor de contrato a largo plazo pide alteración del acuerdo y no se aprovecha de un derecho de salida a coste razonable (aunque no es gratuito), es probable que esté especulando con futuros tiempos mejores. En este caso, el juzgador debe abstenerse y dejar al empresario especulador a su propio riesgo y ventura".

${ }^{208} R J$ 3010. La fianza se había suscrito en garantía de sendos préstamos hipotecarios obtenidos para financiar un proyecto fotovoltaico, cuya base económica, se dice, habría quedado profundamente afectada por el cambio en el régimen jurídico aplicable a la energía solar, sumiendo al sector en una profunda crisis.

${ }^{209}$ Cfr. Carrasco Perera, "Al fin la madre de todas las batallas..." cit., p. 8.

${ }^{210}$ Supra, II, 3 E). 
129. La Nota (ap. 45) suministra, de cara al futuro, ejemplos de los contenidos de específicas previsiones que podrían insertarse en el contrato en relación con todos los aspectos del régimen jurídico de la hardship: i) Cláusulas relativas a cualquiera de los presupuestos y requisitos de la excesiva onerosidad, con mayor o menor detalle en cuanto a circunstancias temporales o espaciales, acaso con períodos de gracia antes de postular la revisión del contrato. O, sobre todo en contratos de larga duración que requieren un considerable nivel de inversión por ambas partes, estas "pueden estar especialmente interesadas en permitir la renegociación", aunque no se cumplan todos los presupuestos establecidos en los Principios, en particular la previsibilidad, con objeto de redistribuir el riesgo de un futuro acontecimiento similar a la presente pandemia. ii) Cláusulas relativas a los efectos de la excesiva onerosidad, para modular o precisar algunos de los aspectos relativos, p. ej., a la renegociación (plazos para instarla o para alcanzar un acuerdo) y su efecto sobre las obligaciones pendientes de cumplimiento. iii) Sobre todo, cláusulas más frecuentes en los contratos internacionales, que prevén las consecuencias del fracaso de la negociación: bien la resolución del contrato, bien su continuación en los términos acordados inicialmente, soluciones algo drásticas que a veces sirven de incentivo para la propia renegociación. Pero también la sumisión a "una instancia neutral de resolución de conflictos o a otro órgano decisorio".

130. Las cláusulas de hardship, en cualquier caso, también habrán de ser objeto de interpretación $^{211}$. Podría pensarse que toda estipulación de atribución de riesgo de alcance general, y formulada antes de la COVID-19, ha perdido vigencia: una pandemia acaso era imaginable, pero los resultados, en su intensidad y escalamiento, son de ciencia ficción. Con todo, la cláusula ya incluida y con enunciado genérico podría entenderse aplicable también en el desastre actual, al menos en la medida en que el riesgo atribuido a una de las partes hubiera podido ser causado también por otras circunstancias imprevisibles, que no fueron excluidas ${ }^{212}$.

\section{Los efectos de la excesiva onerosidad}

\section{A) Renegociar. Esa es la cuestión}

131. La parte perjudicada puede requerir, según el art. 6.2.3 (1), la renegociación del contrato. El requerimiento deberá formularse sin demora injustificada, con indicación de los fundamentos en los que se basa. Pero "no autoriza por sí mismo a la parte perjudicada para suspender el cumplimiento" $(\text { art. 6.2.3 (2) })^{213}$.

132. La renegociación establecida en este precepto es una concreción de los principios de buena fe (art. 1.7 PICC, Good faith and fair dealing) y del deber de cooperación (art. 5.1.3 PICC), cuando sea razonable exigir dicha cooperación al efecto de facilitar el cumplimiento de la otra parte. En particular,

${ }^{211}$ A algunos de estos problemas se refiere también la Nota (ap. 48), por ejemplo, en relación con la inclusión de listas concretas de acontecimientos calificados como causas de excesiva onerosidad, en los que se puede discutir si son meramente ejemplificativas de una descripción más general, o exhaustivas.

${ }^{212}$ GanuZa/Gómez Pomar (op.cit., p. 581) observan que sin duda los instrumentos y los términos del contrato no estaban pensando en la pandemia, pero "parece más prudente dejar que los instrumentos específicos tengan preferencia sobre los generales que podamos idear, aunque es de esperar que su aplicación en la situación de emergencia no se podrá sustraer, o no del todo, al vértigo y las exigencias del momento”. V. CARrasco Perera, A. “¿Podemos excluir por contrato la regla rebus sic stantibus? Un modelo lógico-normativo del cierre de sistema”, CESCO, 20 junio 2020, p. 2, defiende la plena vigencia y eficacia de una cláusula (pre-COVID) de asignación o reparto de "todos los riesgos en general": "Una cláusula de riesgos no puede desactivarse por la ocurrencia de un riesgo que estaba comprendido en la cláusula". La validez y eficacia del pacto que asigne a una de las partes el riesgo extraordinario insólito, que no se hubiera podido prever se apoya, además, en el art. $1575 \mathrm{CC}$, que constituye "el nicho más acomodado para construir en nuestro sistema una regla rebus sic stantibus".

${ }^{213}$ En el Comentario se dice que la renegociación es con vistas a la adaptación del contrato a las nuevas circunstancias, y es subsidiaria respecto a las cláusulas establecidas en el contrato para el evento en cuestión. La exigencia de hacerlo sin demora injustificada y con indicación de sus fundamentos no afecta, se añade, a la facultad en sí de pedir la renegociación, pero sí puede tener trascendencia para decidir si efectivamente había excesiva onerosidad y, en su caso, cuáles deban ser sus consecuencias. 
se recuerda en la Nota (ap. 43), las partes "deberán hacerlo de modo constructivo", "absteniéndose de cualquier forma de obstrucción, y facilitando todas las informaciones necesarias". Ahora bien, como regla general, la parte perjudicada deberá continuar con la ejecución de sus obligaciones. El Comentario lo fundamenta en el carácter excepcional de la excesiva onerosidad, y para evitar su invocación abusiva. No se descarta, empero, que en el caso concreto dicha suspensión pueda estar justificada ${ }^{214}$.

133. Partiendo de estas normas, la Nota recuerda que la renegociación es "particularmente relevante y útil para los contratos de larga duración, donde podría con frecuencia ser interesante para ambas partes tener la seguridad de que circunstancias temporales y excepcionales (como las provocadas por el COVID-19 y las medidas derivadas de él) no frustrarán una relación que, de otro modo se consideraría equilibrada y beneficiosa para ambos". En la situación excepcional creada por la pandemia, la negociación es de especial interés: "un amplio porcentaje de contratos se verán afectados, muchos de ellos contratos comerciales valiosos cuya preservación evitaría conflictos, reduciría costes de transacción adicionales para el sistema, aliviaría los ya sobrecargados sistemas judiciales y de resolución de disputas, y contendría el daño económico".

134. La tendencia, reflejada ya en muchos ordenamientos, se extiende, acaso sobre la huella de los modelos europeos de softlaw $w^{215}$. El art. 1195 del Código francés establece, para el caso de excesiva onerosidad sobrevenida, que la parte que no hubiera aceptado el riesgo del cambio podrá requerir a la otra la renegociación del contrato, advirtiendo también que deberá, no obstante, continuar con el cumplimiento de sus obligaciones durante la renegociación ${ }^{216}$. En Italia, se ha propuesto la modificación de su Código civil para incorporar una previsión similar ${ }^{217}$.

135. Renegociar se ha convertido, sin duda y en este tiempo aciago, en la recomendación más extendida. Desde instituciones o asociaciones privadas ${ }^{218}$, hasta, en otros países, instancias públicas ${ }^{219} \mathrm{u}$ organismos con funciones conexas al poder judicial ${ }^{220}$. En último término, se trata de preservar los con-

${ }^{214}$ Por ejemplo, por un incremento dramático e inesperado de los costes de producción como consecuencia de la aprobación de nuevas medidas legales que incrementan los deberes de seguridad. Quizá el deudor simplemente ni siquiera pueda acometer tal dispendio, a la vista de la previa provisión de fondos o de la financiación obtenida para cumplir con su propia prestación, que de modo extraordinario e imprevisible ha devenido muy insuficiente.

${ }^{215}$ Para un resumen del origen histórico y del estado de la cuestión en varios países europeos, y en los textos de Derecho uniforme, v. RüFner, T., “Art. 6:111: Change of Circumstances”, en JANSEn, N./ Zimmermann, R. (EDS.), Commentaries on European Contract Laws, Oxford University Press, 2018, pp. 900 - 911.

${ }^{216}$ Introducido con la reforma de 2016. V. Fauvarque-Cosson, B., "Does Review on the Ground of Imprévision Breach the Principle of the Binding Force of Contracts?”, en Cartwright, J./ Whittaker, S. (eds.), The Code Napoléon Rewritten. French Contract Law after the 2016 Reforms, Hart Publishing, Oxford, Portland, Oregon, 2017, pp. 187- 205. La norma introducida no es imperativa; las partes pueden modificar o excluir su aplicación (p. 199), en contratos libremente negociados. No se trata, además, de imponer a las partes ningún deber de renegociar, lo que originaría nuevas disputas sobre la mala o buena fe en el cumplimiento de esta obligación.

${ }^{217}$ Sobre este proyecto, v. SIRENA, P., "L'impossibilità ed eccessiva onerosità della prestazione debitoria a causa dell'epidemia di COVID-19", junio 2020 (acceso en https://www.comparativecovidlaw.it/2020/09/28/limpossibilita-ed-eccessiva-onerositadella-prestazione-debitoria-a-causa-dellepidemia-di-covid-19/).

${ }^{218}$ El European Law Institute ha elaborado unos Principios (ELI Principles for the Covid-19 Crisis, acceso https://www. europeanlawinstitute.eu/fileadmin/user_upload/p_eli/Publications/ELI_Principles_for_the_COVID-19_Crisis.pdf), que recomiendan (Principio 13), en caso de excesiva dificultad o incremento significativo de la onerosidad, que por parte de los Estados europeos se incentive (ensure) que las partes, con base en la buena fe, entablen negociaciones, aun cuando no estuviere previsto en el contrato ni en la ley aplicable. Respecto a las recientes propuestas españolas, v. infra, III.7.

${ }^{219}$ El Gobierno británico recomienda encarecidamente a las partes que resuelvan vicisitudes contractuales de modo responsable y mediante la renegociación o acudiendo a sistemas de mediación. V. https://www.gov.uk/government/publications/ guidance-on-responsible-contractual-behaviour-in-the-performance-and-enforcement-of-contracts-impacted-by-the-covid19-emergency, Mayo 2020 (n. 17), junio 2020 (n.13). V. GreGoraCI, op.cit., p. 468.

${ }^{220}$ En Italia, el Ufficio del Massimario, organismo encargado de extraer las máximas o reglas de la doctrina de casación, publicó en mayo de 2020 un informe (acceso en https:/www.cortedicassazione.it/cassazione-resources/resources/cms/documents/Relazione_Tematica_Civile_056-2020.pdf) sobre normativa Covid y cuestiones relacionadas, en el que se incide en la renegociación como exigencia de la buena fe en la ejecución de los contratos, exacerbada con la situación actual, y orientada a la conservación del contrato; en especial, pp. 21 y ss. 
tratos como sustrato de la vida económica y evitar el colapso judicial. El principio general de la buena fe se concreta ahora no solo en la facultad de requerir una renegociación, sino, sobre todo, en una suerte de deber de la otra parte de mostrarse receptiva a lo que sea razonable para preservar el contrato en circunstancias excepcionales. Se trataría del cauce preferible para mantener su vigencia cuando, a tenor de las circunstancias, la extinción de la relación contractual provoque, como efecto dominó, la propagación a otras relaciones contractuales y la destrucción irreparable de un amplio tejido empresarial221.

136. Nuestra jurisprudencia nunca ha mencionado la negociación entre los presupuestos de la

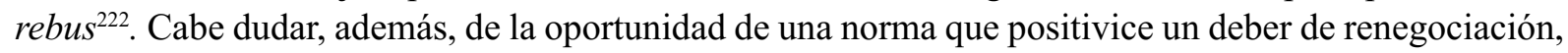
o, todavía más lejos, lo convierta en una suerte de presupuesto procesal para la ulterior reclamación judicial, o que proyecte sobre el régimen de las costas procesales la comparación entre lo obtenido en virtud de la resolución judicial y las propuestas de revisión del contrato ${ }^{223}$. Probablemente baste con fundamentar los deberes de cooperación en el principio general de la buena fe ex art. $1258 \mathrm{CC}^{224}$ y remitir a la doctrina general de la culpa in contrahendo la conducta de quien de mala fe se niega a cooperar para adaptar una situación insostenible de la otra parte, o la de quien de mala fe inicia o interrumpe tales negociaciones ${ }^{225}$.

137. El TS se ha referido en alguna ocasión al deber de intentar una revisión del contrato en caso de alteración extraordinaria de las circunstancias, desde una perspectiva distinta a la que ahora estamos considerando. Lo que el Supremo a veces reprocha al deudor es su decisión de "apartarse unilateralmente" de lo pactado, para luego alegar frente a las pretensiones de cumplimiento o resolución de la otra parte una situación de excesiva onerosidad sobrevenida como excusa de su propio incumplimiento. La buena fe, dirá el Supremo, exige, al menos, que se hubiera dirigido a la otra parte proponiendo un acuerdo, para evitar incumplimientos oportunistas ${ }^{226}$.

138. Este, de algún modo, es el sentido que también podemos extraer de la norma establecida en el art. 6.2.3 (1) y (2) de los PICC. La parte afectada por la excesiva onerosidad podrá y deberá, como exigencia derivada de la buena fe (art. $1258 \mathrm{CC}$ ), proponer una negociación dirigida a conservar una relación en cuya subsistencia siga teniendo interés. Lo que no significa (tampoco en los Principios) un correlativo deber de la otra parte de aceptar la propuesta, ni de llegar necesariamente a acuerdo alguno. La norma supletoria de los PICC sobre la revisión del contrato o su resolución por el Juez presupone, o bien que se ha ignorado la petición de la parte perjudicada, o bien la renegociación infructuosa.

${ }^{221}$ Cfr. Ganuza/Gómez Pomar, op. cit., p. 571 y ss., aunque no en relación con la rebus (que, como tal, no es el instrumento idóneo en las actuales circunstancias, p. 561), sino con las alternativas de intervención legislativa sobre los contratos en vigor: "conservemos los contratos".

${ }^{222}$ Como recuerda la STS de 15 enero 2019 ( $\left.R J 146\right)$.

${ }^{223}$ En el sentido propugnado, por ejemplo, por la propuesta FIDE; v. infra, n. 244. Sin embargo, y en relación con la condena en costas, y como un incentivo para la negociación, considera positivo este tipo de medida SALVADOR CODERCH, op. cit., p. 48.

${ }^{224}$ V. Orellana, L. "El deber de renegociación del contrato en caso de excesiva onerosidad sobrevenida", en Méndez Hornero, C./ Espejo Lerdo de Tejada, M./ Oliva Blázquez, F. (dirs.), Derecho de Contratos: Nuevos Escenarios y Nuevas Perspectivas, Thomson Reuters Aranzadi, Cizur Menor (Navarra), 2016, pp. 437-458, pp. 441 y ss.

${ }^{225}$ V. la crítica de Carrasco Perera, (“Al fin la madre de todas las batallas” cit., p. 10) en relación con la propuesta de la FIDE: "Todo contratante tiene derecho (id est, no está prohibido) a proponer una renegociación y todo cocontratante está sujeto a responder de buena fe a esta propuesta, se dé o no de inicio una contingencia-rebus en la parte que propone". "Todo el que se niega a renegociar de mala fe incurre en culpa in contrahendo. Lo mismo que si empieza a negociar (incluso de buena fe) y luego deja de seguir negociando de mala fe. Las consecuencias no están aquí cualificadas por la rebus".

${ }^{226}$ Según CARrasco Perera (Derecho de Contratos, cit., p. 986): “En verdad, el ‘deber' de negociar no es más que la carga de buena voluntad que debe acreditar el deudor que pretende sea aplicada en su favor la regla rebus. V. GonZÁLEZ PACANOwSKA, “Alteración...", cit., pp. 187 y ss. V., en particular, las SSTS de 17 mayo 1986 (RJ 2725), 17 noviembre 2000 (RJ 9343 ) y 23 abril 2012 (RJ 5913). En un contexto distinto, cual es la frustrada financiación del comprador que pretende, por este motivo, la resolución del contrato, el TS se ha referido indirectamente a esta cuestión, diciendo que, a efectos de admitir o no la rebus, cabría valorar, entre otras circunstancias, "las posibilidades de negociación de las condiciones de pago con el vendedor y, por tanto, como alternativa preferible a su ineficacia”" (STS de 17 enero 2013, RJ 1819). 
139. Parece acertada la exigencia de que tal propuesta de negociación tenga lugar en un plazo razonable, a partir del momento en el que se manifiesten los efectos negativos de los acontecimientos sobrevenidos, entendido esto último con la flexibilidad que requiere la incierta evolución de la actual crisis. La incidencia de la pandemia, y las consecuencias asociadas, sobre la posición del deudor, aunque sean hechos notorios, dependerán de sus particulares circunstancias, por más que algunas se extiendan de modo uniforme a amplios sectores. Pero también deberá facilitarse cuanto antes a la otra parte la adopción de aquellas medidas que puedan ser precisas para reajustar sus propios intereses y evaluar las medidas oportunas, de modo similar a la presencia de un impedimento ${ }^{227}$. Igualmente, y como punto de partida, la petición de una renegociación no justificará, por sí sola, la unilateral suspensión o modificación de la prestación debida. La modulación de esta regla dependerá de las circunstancias del caso concreto ${ }^{228}$.

\section{B) La regla supletoria en defecto de acuerdo}

140. En defecto de acuerdo en tiempo razonable, cualquiera de las partes puede acudir a un tribunal. El Juez podrá, siempre que aprecie una situación de hardship, y "siempre que lo considere razonable”, "(a) resolver el contrato, en la fecha y en las condiciones que se fijen; o (b) adaptar el contrato con objeto de restablecer su equilibrio" (art. 6.2.3. (3) y (4)).

141. La norma confiere amplios poderes al "tribunal" o, en su caso, árbitro. La resolución se puede establecer a partir de determinada fecha (en contrato de tracto duradero), incluyendo previsiones sobre la liquidación de la relación entre las partes. La adaptación consistirá en la medida apropiada para el caso, incluyendo la revisión del precio. Todo lo anterior, "si lo considera razonable". Porque, como se dice en el Comentario, y se recuerda en la Nota (ap. 44), podría no hacer ninguna de esas dos cosas, sino "imponer a las partes que retomen las negociaciones o bien simplemente confirmar los términos del contrato tal como están". Estos amplios poderes suscitan recelos ${ }^{229}$, pero, según algunas opiniones, precisamente esa discrecionalidad judicial sería un incentivo para impulsar el acuerdo en la renegociación, considerada la solución preferible ${ }^{230}$.

142. La regla, como tal, no tiene cabida en el ordenamiento español. El Juez carece de facultades de moderación equitativa, salvo que una norma expresamente se los atribuya ${ }^{231}$. Los principios procesa-

\footnotetext{
${ }^{227}$ V. lo dicho supra, II.5 A), sobre la obligación de notificar al acreedor la existencia del impedimento.

${ }^{228}$ Esta regla constituye una de las razones por las que se rechaza la aptitud de la regla rebus para los contratos en tiempos del COVID (v. Morales Moreno, op. cit., p. 451). Además, aunque sea deseable que las partes lleguen a un acuerdo renegociado libremente, y si todos lo hicieran el resultado sería "ideal", advierte que "una cosa es tomar en cuenta los acuerdos que puedan alcanzar las partes, en cada caso, y otra distinta imponer la negociación para alcanzar acuerdos. Imponer la negociación crea dilaciones, permite al contratante no afectado por el cambio de circunstancias operar con una estrategia oportunista. Prolonga la situación de incertidumbre. Tiene el riesgo de la asimetría en el poder de negociación, lo que no siempre garantiza la corrección del resultado alcanzado". V. también GREGORACI, op. cit., p. 468.

${ }^{229}$ Franciosi, L.M"., "The Effects of Covid-19 on International Contracts: A Comparative Overview”, en Victoria University of Wellington Law Review, 16, 2020, pp.413-438, p. 431 (acceso en http://kirra.austlii.edu.au/nz/journals/VUWLawRw/2020/16. $\mathrm{html}$ ), refiere que, en la contratación internacional, cuando las partes se remiten a los Principios Unidroit como Derecho aplicable, no es infrecuente que excluyan por pacto las disposiciones sobre hardship, evitando de este modo que el Juez tenga poderes para modificar el contrato. La propuesta de cláusula hardship de la ICC (International Chamber of Commerce) de marzo 2020 prevé, en cambio, que la cláusula se formule eligiendo entre tres alternativas. Dos de ellas están enfocadas hacia la resolución (por decisión de la parte perjudicada, o por decisión judicial o arbitral a instancia de cualquiera de las partes), y una tercera remite a los tribunales o al árbitro (a petición de cualquiera de las partes) la decisión de adaptar o de resolver el contrato. Vid. la cláusula propuesta por la ICC en https://iccwbo.org/content/uploads/sites/3/2020/04/icc-clausulas-fuerza-mayor-hardshipmarzo-2020.pdf.

${ }^{230}$ Cfr. Salvador Coderch, op. cit., p. 47 y ss.; Fauvarque-Cosson, op. cit., p. 191.

${ }^{231}$ Como ocurre, por ejemplo, en materia de cláusula penal ex art. 1154 CC. Precepto que, además, es imperativo: el Juez debe moderar si se da el supuesto de hecho de la norma. Y, desde la STS de 13 septiembre 2016 (RJ 4107), es doctrina jurisprudencial que cabe aplicar por analogía el art. 1154 CC para moderar la cláusula penal de cuantía extraordinariamente superior a los daños efectivamente causados cuando esta discordancia (en relación con los daños previsibles en el momento de celebración del contrato) se debiera a una alteración imprevisible de las circunstancias.
} 
les de justicia rogada y congruencia requieren que sean las partes las que en la demanda o, su caso, en la reconvención especifiquen la pretensión ejercitada, sea la de revisión, sea la de resolución, o ambas, de manera subsidiaria, en el orden que se pida en el suplico. La rebus no es una técnica de interpretación integradora para cubrir una laguna contractual ${ }^{232}$. El Juez no puede modificar el contrato como parezca razonable, si nadie lo ha pedido en la demanda o en la reconvención. Dígase lo mismo de la resolución ${ }^{233}$.

143. La jurisprudencia ha mantenido de modo constante que la cláusula rebus tiene efectos "modificativos" del contrato, "encaminados a compensar el desequilibrio obligacional instaurado -lo que supone plantear demanda o, en su caso, su petición por vía reconvencional" 234 , antes que su resolución o extinción ${ }^{235}$. Pretensión esta última que procedería, en principio, solo en los casos de "desaparición total de la base del negocio" o "frustración del contrato". El carácter preferente de la "modificación", probablemente, se originó a raíz de la insistencia del contratante perjudicado en obtener un pronunciamiento de nulidad o de rescisión por extrema onerosidad sobrevenida. La STS de 5 junio $1945^{236}$, sentó el precedente al decir que la pretensión rescisoria "puede enervarse por obra de equitativas modificaciones ofrecidas por el demandado" 237 . Se trataría de evitar que el perjudicado, sin intentar una renegociación, pretendiera de manera oportunista "arrasar por completo", provocando la extinción del contrato. La adaptación del contrato aminora el efecto negativo y permite, en alguna medida, distribuir el riesgo entre las partes y evitar que se cargue íntegramente sobre una de ellas ${ }^{238}$.

144. Sería en cualquier caso deseable, y más en la situación actual, proceder de manera flexible, según las circunstancias de cada caso en particular, sin consideraciones apriorísticas sobre un determinado orden de prelación de remedios, no impuesto por norma alguna. La resolución pretendida por el perjudicado con extraordinarias dificultades sobrevenidas, por ejemplo, podría ser perfectamente razonable teniendo en cuenta, quizá, la negativa de la otra parte a aceptar modificaciones y las alternativas a su disposición para mitigar su daño. O, todo lo contrario, no parece que tenga sentido obligar al acreedor a continuar una relación contractual cuando se ha producido la frustración definitiva de su interés por razón, por ejemplo, de la moratoria extraordinaria que propone la parte perjudicada.

\section{Propuestas normativas para codificar la rebus en tiempos de crisis}

145. La oportunidad de introducir una norma $a d$ hoc ha tenido el aval de la doctrina desde hace años ${ }^{239}$. El TS ha considerado en alguna ocasión que la falta de regulación legal, "agravada por las diversas perspectivas jurídicas con que es contemplada en la doctrina cientifica, genera incertidumbre acerca de la incardinación del tema en el Derecho positivo"240; aunque también declara que se encuentra próxima en su fundamento "a los artículos 7 y 1258 CC para solucionar los problemas derivados de una alteración sobrevenida de la situación existente o de las circunstancias concurrentes al tiempo de la

\footnotetext{
${ }^{232}$ Lo explica con claridad la STS de 22 enero 2019 (RJ 159).

${ }^{233}$ V. Carrasco Perera, Derecho de Contratos, cit., p. 973: "Si el actor pide resolución por la rebus y el demandado niega la procedencia de la cláusula, sería incongruente la sentencia que impusiera una modificación del contrato, no pedida por nadie. El Juez no puede aplicar de oficio la cláusula rebus".

${ }^{234}$ STS de 17 noviembre 2000 (RJ 9343).

235 STS de 20 noviembre 2009 (RJ 7297).

${ }^{236}$ RJ 698.

${ }^{237}$ En este sentido, el art. 1467 del Código italiano.

${ }^{238}$ STS de 17 noviembre 2000 (RJ 9343).

239 V. con cita de otros, Amunátegui Rodríguez, C., La cláusula rebus sic stantibus, Tirant lo Blanch, Valencia, 1993 , p. 23 y p. 325. En relación con la propuesta de la PMCC, SAlvador Coderch, P., pp. 5, 7 y ss.

${ }^{240}$ STS de 17 junio 2005 (RJ 4275), aunque el asunto es un ejemplo más de sorprendente alegación y acertada desestimación de la doctrina rebus, para forzar una modificación unilateral de la contribución a los gastos en función de la cuota de participación en la propiedad horizontal. El TS menciona como posibles vías de penetración de la rebus, "entre otras, las posibilidades del principio de integración contractual de la buena fe objetiva ex art. 1258 CC, la normativa relativa a la causa, o tomar en cuenta los preceptos relativos al equilibrio de las prestaciones en cuanto a los contratos con obligaciones reciprocas".
} 
celebración del contrato "241. Las secciones de Derecho Civil y Derecho Mercantil de la Comisión General de Codificación presentaron sendas propuestas al respecto ${ }^{242}$, aunque ninguna llegó a buen puerto.

146. Inmersos ahora en una situación de crisis de alcance mundial y duración incierta, la ausencia de norma positivizada parece entenderse por algunas opiniones como un factor que podría impedir la alegación de la excesiva onerosidad o frenar su relevancia como instrumento de reequilibrio contractual, en una situación dramática que afecta a amplios sectores de la contratación ${ }^{243}$. Se han publicado algunas iniciativas privadas, con propuestas de textos articulados, que se identifican a sí mismas, no obstante, como regulación excepcional, a modo de respuesta urgente y necesaria para la situación provocada por la COVID-19244.

147. Parece clara, en todo caso, la intención política de, ahora sí, impulsar la promulgación de una norma ad hoc. La Disp. Adicional séptima de la Ley 3/2020, de 18 de septiembre, de medidas procesales y organizativas para hacer frente a la Covid-19 en el ámbito de la Administración de Justicia, dispone bajo el título "Cambio extraordinario de las circunstancias contractuales", que "el Gobierno presentará a las Comisiones de Justicia del Congreso de los Diputados y del Senado, en un plazo no superior a tres meses, un análisis y estudio sobre las posibilidades y opciones legales, incluidas las existentes en Derecho comparado, de incorporación en el régimen jurídico de obligaciones y contratos la regla rebus sic stantibus. El estudio incluirá los datos disponibles más significativos sobre el impacto de la crisis derivada de la COVID-19 en los contratos privados".

148. Como antes hemos señalado, la situación excepcional requiere una intervención directa del legislador que arbitre medidas específicas, de modo inmediato y concreto. Aun así, parece indudable, al menos por ahora, que el limitado alcance de la legislación de urgencia, restringiendo su ámbito de aplicación a algunos tipos de contratos, y supeditando su aplicación a la concurrencia de requisitos subjetivos y objetivos, conducirá a seguir buscando amparo judicial bajo la doctrina rebus. El ejemplo lo suministra el limitado alcance del RDLey 15/2020, en materia de arrendamiento de locales, y la escalada de Autos de los Juzgados de Primera instancia acordando la adopción de medidas cautelares dirigidas, con distinto alcance, a suspender la ejecución de garantías por razón de impago de la renta, así como a obtener el aplazamiento o, incluso, la reducción de la renta ${ }^{245}$. El RDLey 35/2020, de 22 de diciembre, se presenta como "continuación y mejora" de los procedimientos previstos en el RDLey 15/2020, con el fin de reducir los gastos fijos de arrendamientos que soportan empresas y autónomos, que han visto suspendidas sus actividades por razón de las restricciones adoptadas tras la declaración del estado de alarma, o han sufrido importantes reducciones en su facturación. La norma establece requisitos objetivos y subjetivos que habilitan para solicitar una moratoria en el pago de la renta o una reducción de su importe,

${ }^{241}$ SSTS de 17 enero 2013 (RJ 1819) y 18 julio 2019 (RJ 3010).

${ }^{242}$ Propuesta para la Modernización del Derecho de obligaciones y contratos. Comisión General de Codificación. Sección de Derecho Civil. Ministerio de Justicia, 2009. El art. 1213 de la PMCC intitulado "De la alteración extraordinaria de las circunstancias básicas del contrato", se inspira en el § 313 BGB. En cuanto a la propuesta mercantil, se contiene en el art. 416-2 del Anteproyecto de Ley de Código Mercantil de 30 de mayo de 2014, siguiendo con total fidelidad el modelo de los Principios Unidroit.

${ }^{243}$ V., p. ej., la opinión de Gómez LigüerRe, supra, n. 3.

${ }^{244}$ La Fundación para la Investigación del Derecho y la Empresa (FIDE) publicó el 21 de abril 2020 la propuesta elaborada por su denominado "Gabinete de crisis" (acceso en https://www.fidefundacion.es/attachment/1912172/) para la alteración extraordinaria que sea "consecuencia de la pandemia del Covid19 o de la situación económica causada por ella". De otra propuesta que se ha hecho llegar, al parecer, al Ministerio de Justicia, elaborada por el grupo denominado "CovidWarriors", publicado en Diario La Ley, n. 4992, de 23 de junio 2020, da noticia PASQuau Liaño, M., "Covid-19: los contratos también se contagian. ¿Hay fórmulas para mitigar el colapso judicial?”, en Diario La Ley, n.9665, de 2 de julio 2020.

${ }^{245}$ El JPI No 31 Barcelona, Auto n. 348/2020, de 21 septiembre (JUR 290355) desestima íntegramente la pretensión, aunque admite que la rebus podría sustentar una rebaja de la renta para el tiempo que el local permaneció cerrado. V. además: JPI N 1 San Sebastián, Auto n. 262/2020, de 6 octubre (JUR 291842), JPI No 74 Madrid, Auto n. 299/2020, de 13 agosto (JUR 251694, que admite la suspensión en la ejecución de garantías), JPI No 81 Madrid, Auto n. 447/ 2020 (JUR 287502) y JPI No 1 Valencia, Auto n. 256/2020, de 25 junio (JUR 202178). 
prevaleciendo en cualquier caso lo que las partes hubieran acordado sobre aplazamiento o reducción ${ }^{246}$. Pero, de nuevo, los límites objetivos, subjetivos y temporales previstos (la solicitud del arrendatario ha de tener lugar, como máximo, el 31 de enero de 2021) dejarán fuera de su ámbito de aplicación muchos contratos en los que la rebus podría justificar una adaptación de lo pactado, sobre todo a través de reducciones temporales (en caso de prohibición de apertura) y aplazamientos, en función del caso concreto, o la terminación de la relación contractual.

149. El problema, como ha sido reiteradamente advertido, es la elevada litigiosidad y el consiguiente colapso judicial. Aunque se diga que la legislación excepcional deberá conducir a rechazar las demandas que pretendan medidas distintas (a favor de una u otra parte), dentro de su respectivo ámbito de aplicación, el problema persiste, al menos, para todos los contratos no incluidos en aquellas normas; normas que, como tales, no deberán ser aplicadas "a supuestos ni en momentos distintos de los comprendidos expresamente en ellas" (art. 4.2 CC).

150. La aplicación de la rebus por parte del TS tiene lugar sin necesidad de expreso reconocimiento en la ley, y su eventual regulación positiva tampoco sería la panacea, aunque podría clarificar algunos aspectos relativos a la negociación. Cualquiera que sea la formulación de una norma al respecto, implica, por definición, una atenta consideración del tipo contractual, de la distribución legal y contractual de riesgos, y de la incidencia de las circunstancias sobrevenidas sobre la posición jurídica de ambas partes. Además, aunque no siempre se ha explicitado, no podrá prescindirse en su aplicación de las ayudas públicas obtenidas, ni de las medidas que la parte perjudicada hubiere adoptado, o debía haber adoptado, para mitigar su propio daño.

151. El tiempo extraordinario que vivimos obliga sin duda a subrayar las ideas en torno a la cooperación de las partes en el ámbito contractual, así como la disposición a renegociar los contratos bajo el signo de la buena fe. Es indudable que las partes son los mejores árbitros de su propia relación contractual y cuentan con toda la información relevante. No parece el mejor momento para improvisar una norma que amplíe considerablemente el marco de decisión equitativa del Juez, ni siquiera como incentivo para la deseable renegociación.

\section{Conclusiones}

152. La atenta lectura de la Nota elaborada por el Secretariado de Unidroit sobre la aplicación de los PICC en el contexto de la crisis generada por el coronavirus puede aportar interesantes perspectivas a la hora de interpretar y aplicar las normas nacionales que regulan instituciones básicas del Derecho de obligaciones y contratos, en especial las relacionadas con la fuerza mayor/caso fortuito, imposibilidad sobrevenida, excesiva onerosidad/rebus sic stantibus, etc. Desde el punto de vista del Derecho español, algunas reflexiones pueden resultar especialmente interesantes.

153. En lo que se refiere al régimen de la fuerza mayor, parece acertada la utilización de un concepto flexible de "impedimento" que facilite la aplicación de dicha figura más allá de los límites estrictos de la imposibilidad sobrevenida de la prestación, evitando así, por ejemplo, la necesidad de establecer una delimitación nítida - no siempre posible en la práctica-, entre el ámbito de aplicación de

\footnotetext{
${ }^{246}$ Para una visión crítica, v. FuEntes-Lojo Rius, A., "Últimas novedades en arrendamientos de uso distinto de vivienda e industria en tiempos de pandemia. Comentarios al RDL 35/2020", en Diario La Ley, n 9765, 7 de enero de 2021, pp. 1-12. El Gobierno Catalán ha promulgado, por su parte, el Decreto Ley 34/2020, de 20 de octubre, de medidas urgentes de apoyo a la actividad económica desarrollada en locales de negocio arrendados. Sobre la norma catalana, en particular, v. las observaciones críticas de Gómez Pomar, F., en el editorial "Después de diez años", InDret, n. 4, 2020; y Carrasco Perera, A., "Alquileres catalanes anti-Covid. Una antología de Derecho Malo", en CESCO, 29 octubre 2020, pp. 1-10. Desde una perspectiva más amplia, sobre los efectos de las moratorias y de las quitas en los contratos de arrendamiento, v. GANUZA, J.J./ GómEz Pomar, F., "Los instrumentos...", cit., en especial pp. 576 y ss.
} 
la imposibilidad propiamente dicha y el de otros instrumentos, como la frustración del fin del contrato, la desaparición de la base negocial, la inexigibilidad, conforme a la buena fe, del cumplimiento estricto de la obligación, o el extraordinario desequilibrio sobrevenido entre las prestaciones del contrato sinalagmático. Resulta igualmente oportuna la distinción entre los requisitos de la fuerza mayor, como fundamento de la exoneración de la responsabilidad del deudor, y los presupuestos de aplicación de otros remedios frente al incumplimiento contractual, como son la resolución, la suspensión del contrato, o el pago de intereses por la mora en las obligaciones dinerarias, que deberán afrontarse desde una perspectiva necesariamente distinta. Desde el punto de vista práctico, consideramos especialmente relevante la expresa formulación del deber, a cargo del deudor que pretenda alegar la fuerza mayor exoneratoria, de comunicar al acreedor la existencia del impedimento y su incidencia sobre la capacidad de cumplimiento del propio deudor, fundamental para la debida preservación de los intereses de ambas partes.

154. En cuanto a la excesiva onerosidad, el régimen jurídico contenido en los PICC representa casi el Derecho común europeo en la materia, reflejado tanto en las propuestas de Derecho uniforme, como en recientes reformas legislativas, y ha sido citado en reiteradas ocasiones por el TS español como modelo para la interpretación de la regla rebus sic stantibus, de creación jurisprudencial. En las actuales circunstancias, resulta de especial interés la importancia que se otorga a la renegociación, como exigencia y manifestación de la buena fe, tanto en el requerimiento de la misma como en su desarrollo. La renegociación es la vía más adecuada para preservar la relación y evitar, especialmente en tiempos de crisis, los efectos expansivos de la destrucción del tejido contractual. Parece también acertada la regla que no autoriza al deudor a suspender unilateralmente su propio cumplimiento por la propuesta de renegociación y mientras dure el proceso, en aras de evitar estrategias oportunistas. Consideramos igualmente conveniente resaltar que, en defecto de acuerdo, las consecuencias de estimar la excesiva onerosidad deberán articularse del modo que mejor convenga al caso concreto, sin estar condicionadas por un juicio apriorístico acerca de su orden de prelación, y sin perjuicio del necesario respeto a los principios procesales de justicia rogada y congruencia.

155. Los instrumentos generales del Derecho de obligaciones y contratos difícilmente pueden servir para dar una respuesta adecuada al ingente número de conflictos jurídicos que están surgiendo y, previsiblemente, van a surgir a raíz de la pandemia y sus derivaciones (medidas restrictivas, crisis económica). No cabe ignorar, sin embargo, su trascendencia, habida cuenta de los límites que, por razones obvias, habrá de tener siempre la legislación de emergencia dictada, o que se pueda dictar, en los próximos meses (quizá años) para atender a los problemas más urgentes. 